\title{
GUÍA DEL ARCHIVO DE LA ANTIGUA ACADEMIA DE SAN CARLOS \\ $1781-1800$
}


DOI: http://dx.doi.org/10.22201/iie.18703062e.1968.sup3 


\section{JUSTINO FERNÁNDEZ}

\section{Guía del Archivo de la Antigua Academia de San Carlos 1781-1800}


DOI: http://dx.doi.org/10.22201/iie.18703062e.1968.sup3

Primera edición: 1969

Derechos reservados conforme a la ley

(C) 1969, Universidad Nacional Autónoma de México

Ciudad Universitaria. México 20, D. F.

Dirección General de Publicaciones

Impreso y hecho en México

Printed and made in Mexico 


\section{Advertencia}

Hace ya años que me propuse formar una guía del archivo de la antigua Academia de San Carlos, pues pensé, como se comprende fácilmente, que sería una valiosa ayuda para los estudiosos de nuestra historia del arte. Puse manos al asunto $y$, con el permiso respectivo del director de la Escuela de Arquitectura, donde se conserva el archivo, en unas cajoneras con cortinas, empecé desde la primera gaveta, permitiéndome numerar cadla uno de los documentos con lápiz, suavemente, en el ángulo derecho.

Así, logré registrat 1035 documentos, que abarcan desde agosto de 1781 hasta agosto de 1800, resumiendo de cada uno lo esencial de su contenido. En verdad el periodo cubierto se refiere de manera principal al establecimiento de la Real Academia de las Tres Nobles Artes, Pintura, Escultura y Arquitectura, la cual por haber sido aprobada y quedar bajo el patrocinio de Carlos III, llevó el nombre de San Carlos de la Nueva España.

Mas, también en el lapso que abarcan los documentos se encuentran muchos datos de importancia sobre los primeros maestros y directores de los diferentes ramos de la enseñanza que se impartía, sobre los pensionados y otros aspectos, todo de acuerdo con los Estatutos que se formularon y aprobaron en 1785.

Es sabido que la academia fue fundada en el tiempo en que imperaba la corriente neoclásica en el arte y uno de sus principales objetivos fue restablecer los principios clásicos, que se consideraban el "buen gusto", después de la exuberancia que alcanzó el arte ultrabarroco, al que se le puso un brusco final. Los documentos muestran el funcionamiento de la academia como vigilante de que se cumplieran las nuevas reglas $y$, así los proyectos de arquitectura, por ejemplo, quedaban sujetos a una severa crítica, antes de ser realizados. En 1791 se formó una "Nómina de Pintores y Obradores (talleres) de pintura que hay en la Ciudad de México", para saber cuáles podían ser autorizados, lo que promovió algunas dificultades. También se formaron nuevas ordenanzas de pintores y doradores. El nuevo espíritu y orientación queda resumido en un escrito de Manuel Tolsá, director que fue de Escultura, dice así: Deseando el mayor y más 
pronto adelantamicnto de las Artes ... hago presente que uno de los más eficaces medios es la propagación del buen gusto, pues sin éstc son casi inútiles las Bellas Artes, las que tratadas sin el aprecio que es hijo de un delicado discernimiento se sepultan en la ignorancia ... (1795). Y ya sabemos que el "buen gusto" era el neoclásico.

No es el caso repetir aquí una vez más la historia de la fundación de la academia, el interesado encontrará muchos datos sobre ella y sus primeros maestros en esta guía, y más si consulta los documentos mismos.

Por haberme llamado otras ocupaciones urgentes no me ha sido posible llevar más allá la investigación, mas la parte realizada ya ha servido para orientar a varios estudiantes en sus trabajos y tesis, por lo que he decidido publicarla con objeto de hacerla accesible a un mayor número de estudiosos. Ojalá y me sea posible continuar en el futuro esta guía o bien que se interese en continuarla algún estudioso. Al respecto debo decir que lat maestra Alicia Leonor Cordero Herrera presentó una interesante tesis para optar por el grado de Maestra en Historia de las Artes Plásticas, en 1967, en la Universidad Iberoamericana, con el título de La Academia de San Carlos dentro del movimiento de la Ilustración en México, para la cual tuvo en sus manos la guía del archivo que ahora se publica. La maestra Cordero Herrera catalogó por su cuenta 607 documentos más. que abarcan desde julio de 1801 hasta diciembre de 1821 (apéndice 1 de la tesis), continuando la numeración que inició quien escribe, del número 1136 al 1743. Sería de desear que se publicara dicho trabajo por el interés que tiene la tesis y la documentación que la acompaña.

Sea como sea el presente trabajo es un principio que no obstante su limitación en el tiempo puede prestar alguna utilidad y por eso no parece superfluo darlo a conocer.

Doy las gracias al maestro Eduardo Sánchez Vega por haber puesto en limpio mis tarjetas y al señor Danilo Ongay Muza por la formación del índice de nombres.

JUSTINO FeRNÁNDEZ

Septiembic de 1968 


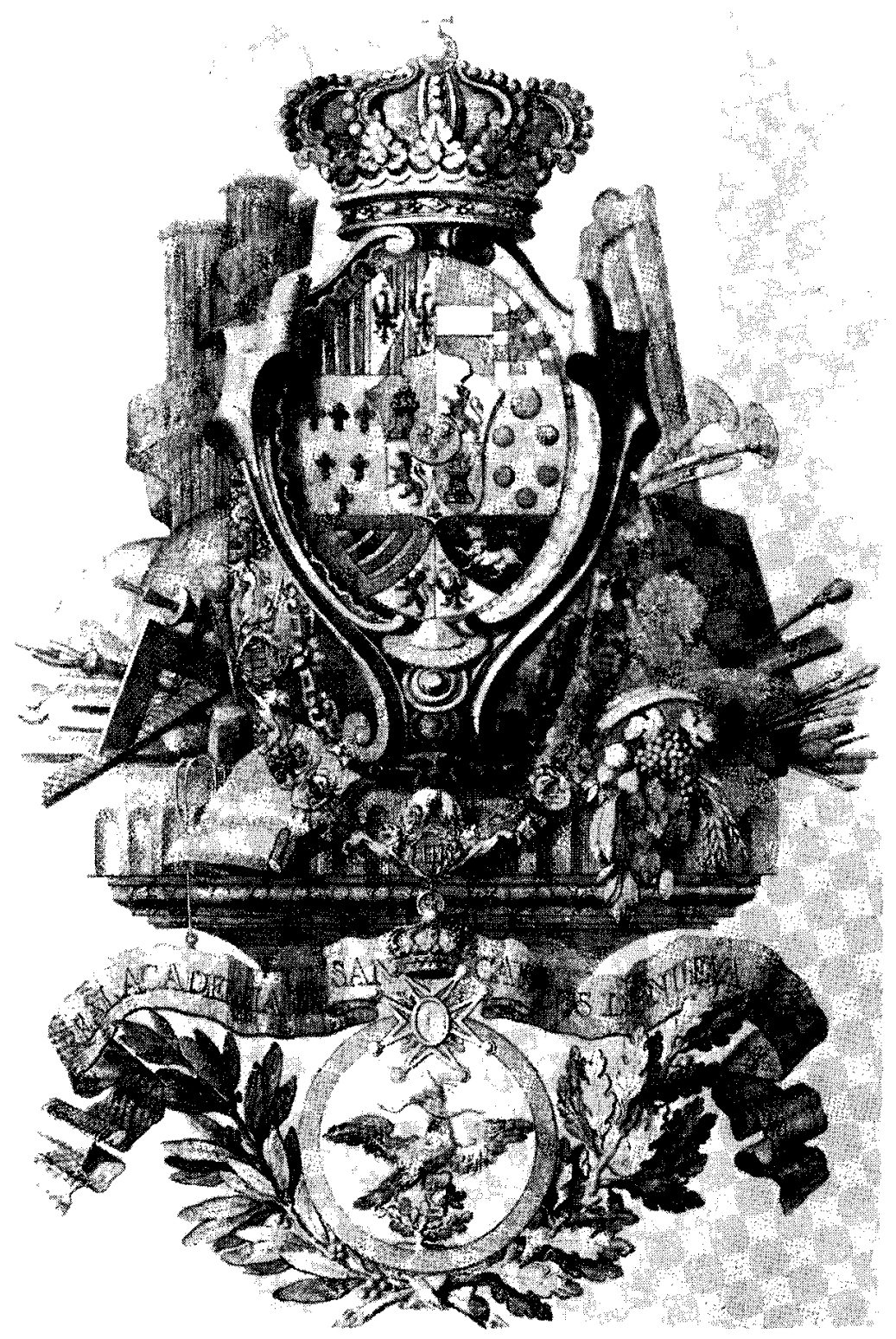

Escudo de la Real Academia de San Carlos 
DOI: http://dx.doi.org/10.22201/iie.18703062e.1968.sup3 
LEgajo CONTENIENDO: (PORTADA MANUSCRITA) EXPEDIENTE ORIGINAL FORMADO SOBRE EL ESTABLECIMIENTO DE LA REAL ACADEMIA DE LAS TRES NOBLES ARTES, QUE CON LA DENOMINACIÓN DE SAN CARLOS DE NUEVA ESPAÑA SE SIRVIÓ S. M. APROBAR, Y DOTAR CON LA CANTIDAD DE TRECE MIL PESOS ANUALES, TOMÁNDOLA BAJO SU REAL INMEDIATA PROTECCIÓN POR REAL ORDEN DE 25 DE DICIEMBRE DE 1783, CON UNA COPIA IMPRESA DE ELLA, Y OTRA IGUAL DEL BANDO PUBLICADO EN EL ASUNTO (RÚBRICA) *

Gaveta 1. 1781-1791 (números del 1 al 48).

1. Proyecto de don Fernando José Mangino para el estab'ecimiento en México de un "Estudio Público de Artes". Dirigido al virrcy don Martín de Mayorga. Real Casa de Moneda. Agosto 29 de 1781 (rúbrica).

2. Decreto del virrey aprobando el proyecto de Mangino y ordenando se hagan las diligencias necesarias. México, 12 de septiembre de 1781.

3. Oficio del virrey a don Fernando José Mangino acompañando copia de la consulta acerca del proyecto para el estab'ecimiento de una academia o escuela de las Tres Nobles Artes de Pintura, Escu'tura y Arquitectura, asimismo del decreto de aprobación. México, 17 de septiembre de 1781 (rúbrica).

4. Oficio de don Fernando José Mangino al virrey acusando recibo de la consulta y del decreto y sugiriendo que ambos se impriman "en breves Villetes" para evitar hacer oficios y "para dar idea, e instrucción al Proyecto". Agrega que él costeará la impresión. México, 22 de septiembre de 1781 (rúbrica). Al margen: Acuerdo del virrey para que se proceda a la impresión (rúbrica).

5. Oficio del virrey a don Fernando José Mangino remitiendo el expediente a efecto de que proceda a la impresión según su anterior consulta. México, 26 de septiembre de 1781 (rúbrica).

6. Oficio de don Fernando José Mangino al virrey dando cuenta de las cantidades con que se han suscrito algunas instituciones y particulares y proponiendo la forma en que se había de organizar la junta preparatoria y los individuos que debían componerla. México, 4 de abril de 1782 (rúbrica).

Acuerdo del virrey en que elige y nombra a los individuos que propone don Fernando José Mangino y orden de que se devuelva al

* Este legajo contiene los documentos que aqú se resumen. 
mismo el expediente y se pase aviso a los electos. 6 de abril de 1782.

7. Oficio del virrey a don Fernando José Mangino remitiéndole el expediente para que desde luego proceda a la formación de la junta. México, 6 de abril de 1782 (rúbrica).

8. Oficio de don Fernando José Mangino al virrey informándole que había tenido lugar una reunión de los miembros de la junta preparatoria y que acordaron pedirle su presencia para la primera sesión formal. Pide Mangino resuelva el virrey provisionalmente el lugar de asiento y firma que han de ocupar las Diputaciones de la ciudad, el Consulado de Comercio y Real Tribunal de Minería, mientras se resueiven los Estatutos. México, 27 de junio de 1782 (rúbrica).

$\mathrm{Al}$ margen: Acuerdo del virrey señalando fecha para la primera junta en el Real Palacio el 25 de abril ? a las 10 de la mañana y dispone el orden que deberán tener. México, 22 de junio de 1782 (rúbrica).

9. Oficio de don Gerónimo Antonio Gil a los señores viceprotector y consiliarios. Pide que se den materiales a los "Discípulos de notoria pobreza" y enumera lo necesario para el caso, y su costo. México (sin fecha) (rúbrica). Al margcn: Acuerdo del secretario de la junta, don José Ignacio Bartolache. "Como se pide..." Julio 4 de 1782. México.

10. Oficio de don Gerónimo Antonio Gil a los señores viceprotector y consiiarios. Informa acerca de los profesores que se pueden pedir a la corte para primeros maestros de pintura, escultura y arquitectura, de primero y segundo grado, así como de las estatuas y demás vaciados en yeso y libros de adornos y galerías. México, julio 18 de 1782 (rúbrica). Al margen: Acuerdo del secretario Bartolache. "Téngase presente..." Jưio 18 de 1782.

11. Memorial de la junta preparatoria al virrey don Matías de Gálvez. Informan sobre el buen éxito a'canzado en los estudios de la escuela del grabado, de la Real Casa de Moneda; la iniciativa del superintendente Mangino para el establecimiento de una academia $y$ auguran mucha prosperidad al establecimiento. Exponen los antecedentes, las gestiones hechas ante S. M. y el ministro de Indias, todavía sin resultado efectivo. Dan cuenta del reparto de premios del día 25 de agosto con motivo de celebrarse el cumpleaños de la Princesa de Asturias y finalmente, encarecen al virrey informe nuevamente a S. M. y le recomiende el asunto. México, mayo 22 de 1783 (14 rúbricas de los miembros de la junta). En la primera foja está el acuerdo de Gálvez y dice que ha recibido una Real Orden para que oído el señor fiscal don Ramón de Posada informe lo que se ofreciere acerca del establecimiento. Para esta consulta se acom- 
pañan todos los antecedentes al señor ministro para que pida lo que estimare conveniente (rúbrica). 22 de mayo de 1783 .

12. Impreso. "Proyecto para el Establecimiento en México de una Academia de las Tres Nobles Artes, Pintura, Escultura y Arquitectura". 7 fojas en $8^{\circ}$.

13. Copia certificada de la Real Orden, dada en el Pardo a 12 de enero de 1783, dirigida a don Matías de Gálvez, virrey de Nueva España. Expone los antecedentes relativos a la idea de Mangino; pide que el virrcy cxamine el asunto, oyendo al fiscal don Ramón de Posada y que informe.

14. Nota de todos los sujetos que han contribuido por una vez para fondos de la futura Academia de las Tres Nob'es Artes, con expresión de las cantidades que remitieron (sigue la lista de personas y cantidades). México, 16 de junio de 1783. Antonio Piñeiro, secretario (rúbrica).

15. Nota de los que contribuyen anuaimente, así el Ilustre Ayuntamiento de esta capital y otros cuerpos de ella, como algunas ciudades y villas foráneas para la subsistencia de la futura Academia de las Tres Nobles Artes (sigue la lista). México, 16 de junio de 1783. Antonio Piñeiro, secretario (rúbrica).

16. Estado de la renta anual que tiene la escuela provisional de dibujo para la futura academia. Establecida en la Real Casa de Moneda de esta capital. Erogaciones desde el 5 de noviembre de 1782, en que se abrió, hasta el 5 de mayo del corriente. Renta anual. Gastos erogados en el referido tiempo. Cotejo. Notas. Se advierte que de aprobarse el establecimiento definitivo habrá de necesitarse de 25 a 30 mil pesos anuales para cubrir los gastos y aplicar el sobrante a la compra de un terreno y a la construcción de una casa propia para el efecto, pues no caben los alumnos en Jas cortas y cstrcchas piezas de ja Real Casa de Moneda. México, 16 de junio de 1783. Antonio Piñeiro, secretario (rúbrica).

17. Informe del fiscal don Ramón de Posada. Alude a la importancia del estudio del dibujo en relación con las artes y los oficios; dicc que los anteriores virreyes de Nueva España aplicaron sus desve.os a la formación de ordenanzas de los oficios, así como de las artes, desde don Luis de Velasco (en 1557) y el conde de Paredes (1686). Se queja de que por falta de producción nacional se consuman las obras extranjeras; recuerda el permiso de Carlos I (1548) para el establecimiento de telares en Puebla y la prevención de Felipe II (1565) para que en las fábricas de paño se guarden en las Indias las Leyes de Castilla, y tras de citar algunas otras ordenanzas con- 
cluye en la necesidad de la enseñanza del dibujo y del establecimiento de una Real Academia de las Tres Nobles Artes. México, 13 de julio de 1783. Posada (rúbrica).

Acuerdo del virrey Gálvez. "Como pide el Sr. Fiscal ... dar cuenta a S. M. ..., etc." En carta de 31 de ju'io de 1783. Se dio cuenta a S. M. Losada (rúbrica).

18. Minuta de la carta dirigida por el virrey a S. M. por conducto de don Joseph de Gálvez. En cumplimiento de la Real Orden de 12 de enero informa sobre el proyecto de establecer una academia en esta capital. Remite íntegra copia del expediente. Da su opinión en el sentido de que sea durante "el g orioso Reinado" de Car.os III cuando se aprobase y erigiese esta academia bajo el título de "San Car.os de Nueva España" y de la real e inmediata protección de $\mathrm{S}$. M. Dice que se remitan desde luego los profesores, muebles, instrumentos y materiales; que otra junta se dedique a formar los estatutos, y pide una dotación de 12 a 15 mil pesos anuales. Agrega que será necesario construir un edificio exprofeso para el nuevo instituto y que en un cajón remite -la junta- varios dibujos de los a umnos de la escuela de la Real Casa de Moneda. México, 31 de julio de 1783. Matías de Gálvez.

19. Impreso. El virrey don Matías de Gálvez informa sobre la Real Orden con que el monarca "se ha servido aprobar, erigir y establecer en esta ciudad por Real Orden de 25 de diciembre del año pasado de 1783 una Real Academia de las Nobles Artes de Pintura, Escu tura y Arquitectura con el título de S. Carlos de Nueva España baxo su Inmediata Soberana protección". Acompaña copia certificada (al superintendente de la Casa de Moneda). México, 30 de marzo de 1784 (rúbrica) (una hoja en $8^{\circ}$ ).

20. Copia certificada, por Francisco Fernández de Córdova, de la Real Orden para el estab.ecimiento de la academia. Expone los antecedentes; concede un dote de $\$ 9,000.00$ "sobre las Reales Caxas de esa capital" y $\$ 4,000.00$ "en el producto de las Temporalidades", a partir del mes de enero de 1784; queda erigida, establecida y aprobada la Rcal Academia de las Artes con el título de San Carlos de Nueva España; trata otros detalles de la organización y manda publicar la noticia. Madrid.

25 de diciembre de 1783. Josef de Gálvez al señor virrey de Nueva España.

Decreto de obedecimiento. México 17 de marzo de 1784.

"Hágase, guárdese y execútese lo que S. M. manda en la antecedente Real Orden ... ete." Gálvez.

Es copia clel original. México. 
23 de marzo de 1784. Francisco Fernández de Córdova (rúbrica). ( 4 foj. en $8^{\circ}$ ).

21. Impreso (un pliego entero).

Bando del virrey de Nueva España en que transcribe la Real Orden para el establecimiento de la academia. México.

2 de abril de 1784. Matías de Gálvez (rúbrica), por mandato de S. E. Joseph de Gorráez (rúbrica).

22. Impreso. "Proyecto para el establecimiento en México de una Academia ..." (ejemplar igual al No 12).

23. Impreso (otro ejemplar igual al anterior).

24. Oficio de don Joseph de Gálvez a don Fernando José Mangino acusando recibo de un ejemplar impreso del proyecto que presentó al virrey don Martín de Mayorga. Dice que ya avisará lo que el rey resuelva. El Pardo, 12 de enero de 1783 (rúbrica).

25. Oficio del Real Tribunal de la Minería asignando la cantidad de cinco mil pesos anuales para la subsistencia de la academia con la calidad que expresa. Al señor don Martín de Mayorga. México, diciembre 22 de 1781. Juan Lucas Lassaga, Joaquín Velásquez de León, Ramón Luis de Liceaga, Antonio de Vil anueva (rúbricas). Al margen: Contestada en 29 de diciembre de 1781.

26. Minutas de contestación al Real Tribunal de la Minería. Se acepta el donativo según las condiciones expresadas en el oficio anterior. Martín de Mayorga, 29 de diciembre de 1781.

27. Oficio del Real Tribunal de la Minería a don Fernando Mangino. Acompañan el oficio dirigido a don Martín de Mayorga. México, diciembre 22 de 1781. Juan Lucas Lassaga, Joaquín Vèásquez de León, Ramón Luis de Liceaga; Antonio de Villanueva (rúbricas). Al margen: Contestada en 29 de diciembre de 1781.

28. Copia del oficio de don Fernando José Mangino al Real Tribunal de la Minería, aceptando en nombre del rey y de la futura academia sus ofrecimientos. México, 29 de diciembre de 1781. Fernando Josef Mangino.

29. Oficio del Real Tribunal del Consulado asignando la cantidad de tres mil pesos anuales para la subsistencia de la academia, desde el año 1782. México, 16 de noviembre de 1781. Antonio Barroso y Torrubía, Pablo Ximénez de la Plaza, Antonio de Bassoco (rúbricas).

30. Copia del oficio del virrey al Real Tribunal del Consulado, agradeciendo en nombre de S. M. la donación. México, 20 de noviembre de 1781 . 
31. Oficio de esta nobilísima ciudad asignando un mil pesos anuales para la subsistencia de la academia, desde el año presente de 1782. Propone que don Fernando José Mangino sea el viceprotector de la academia durante su vida. México, febrero 25 de 1782 (once rúbricas).

32. Copia del oficio de don Martín de Mayorga a la nobilísima ciudad de México, dando las gracias a nombre de S. M., por el donativo y reservando al rey la reso'ución acerca del nombramiento del viceprotector. México, marzo 4 de 1782.

33. Oficio del Cabiido a don Fernando José Mangino remitiéndole el acuerdo dirigido al virrey don Matías de Gálvez. México, febrero 25 de 1782 (once rúbricas).

34. Copia del oficio dirigido por don Fernando José Mangino a los señores corregidor y capitulares de la nobilísima ciudad de México. Da las gracias e informa que ya pasó al virrey la carta. México, 4 de marzo de 1782.

(Aquí termina el legajo No 1).

35. Oficio dirigido al superintendente de la Real Casa de Moneda. Donación que hizo don José Alcíbar de cuatro tableros, para el uso de la academia.

José de Alcíbar, natural de la ciudad de Texcoco. "Donación de un tablero de seis Apóstoles agrupados por ser Doctrina de la Célebre Escuela de Zurbarán y los tres más pequeños de la de Miguel Angel" (rúbrica).

Al margen: (acuerdo) que se aceptan y se le dan las gracias. 15 de octubre de 1781. Fernando José Mangino (rúbrica) ante mí. José Antonio de Morales (rúbrica).

36. Copia del oficio dirigido al virrey don Martín de Mayorga, por los miembros de la junta preparatoria, pidiendo que señale día y hora para la primera junta. Junio 21 de 1782.

Adjunta una hoja que dice: "Para una junta que se ha de celebrar en el Real Palacio el día martes 25 del corriente a las diez de la mañana, manda el Exmo. Sr. Virrey convocar a los Sres. siguientes: D. Fernando José Mangino, Dn. Fco. Anto. Crespo, D. José Ãngel de Cuevas y Aguirre, D. Anto. Bassoco y Torrubia, D. Anto. Bassoco, D. Juan Lucas de Lassaga, D. Joaquín Velásquez de León, el Marqués de Ciria, Mariseal de Castilla, el Marqués de San Miguel de Aguayo, Dr. D. José Ignacio Bartolache, D. Gerónimo Antonio Gil. 23 de enero de 1782. Dr. Bartolache" (rúbrica).

36 a. Memoriales de varios profesores y pensionados de la academia. 1783 (legajo conteniendo los documentos números 36b, 36c y 36d). 
36 b. Solicitud de Francisco Reales para pensionado de dibujo (rúbrica) sin fecha, 1783.

36 c. Solicitud de Tomás Suría, José Esteve y Bernardo Gil, pensionados por la oficina del grabado de la Real Casa de Moneda, pidiendo se le gratifique por los trabajos de dibujo ejecutados para la enseñanza en la academia (rúbricas).

Al margen: Se mandaron librar $\$ 40.00$ para Suría, $\$ 25.00$ para Esteve y $\$ 22.00$ para Gil y se mandaron poner en la lista de los premios que se han de distribuir el 4 de noviembre. Octubre 3 de 1783 (rúbrica).

36 d. Solicitud de Mariano Saravia y José Joaquín Rodríguez que prestaban sus servicios como modeios para que se les aumente el sueldo, pues de no ser así no podrían continuar. México, julio 6 de 1784 (rúbricas).

Al margen: "Vista en junta se les mandó pagar a razón de 4 reales diarios y 6 el día que trabajen" (rúbrica).

37. Impreso. Lista de los premios "cuya distribución se ha de hacer el 25 de éste (y será la quinta) ..." (con nombres de los estudiantes y cantidades) don Antonio Piñeiro, segundo secretario. México, mayo 22 de 1783 (una hoja de 30 x 41 cms.).

38. Impreso. Lista de premios "cuya distribución se ha de hacer el 26 de éste (y será la sexta) ..." (con nombres de los estudiantes y cantidades). Don Antonio Piñeiro, segundo secretario. México, julio 17 de 1783 (una hoja de 30 x $41 \mathrm{cms}$.).

39. Impreso. Lista de premios "cuya distribución se ha de hacer el 4 del inmediato Noviembre (y será la sépíima)" (con nombres de los estudiantes y cantidades). Don Antonio Piñeiro (una hoja de $30 \mathrm{x}$ 41 cms.), México, 30 de octubre de 1783.

40. Impreso. Lista de premios "cuya distribución se ha de hacer el 22 del corriente (y será la octava) (con nombres de estudiantes y cantidades). Don Antonio Piñeiro, segundo secretario. México, 12 de febrero de 1784.

41. Oficio del Cabildo de la ciudad de México al virrey don Matías de Gálvez acusando recibo del oficio en que se aceptó la donación anual a la academia (siete rúbricas). Mćxico, abril $1^{\text {o }}$ de 1784 .

42. Oficio del Tribunal de la Minería al virrey, acusando recibo de la Rea] Orden (impresa) acerca del establecimiento de la academia (tres rúbricas). México, abril 19 de 1784.

43. Oficio de Miguel Ignacio de Miranda al virrey, acusando recibo de la Real Orden (impresa) acerca del establecimiento de la academia (rúbrica). Veracruz, 21 de abril de 1784. 
44. Oficio de Ignacio Muñoz al virrey acusando recibo de la Real Orden (impresa) acerca del establecimiento de la academia (rúbrica). 21 de abril de 1784.

45. Oficio de Sebastián Pérez al virrey acusando recibo de la Real Orden (impresa) acerca del establecimiento de la academia (rúbrica). Veracruz, 21 de abril de 1784.

46. Oficio del Cabildo de la ciudad de Orizaba al virrey, avisando recibo de la Real Orden (impresa) acerca del establecimiento de la academia (rúbrica). Orizaba, 21 de abril de 1784 .

47. Oficio de Francisco A. de Medina al virrey, acusando recibo de la Real Orden (impresa) acerca del establecimiento de la academia (rúbrica). Veracruz, 21 de abril de 1784.

48. Oficio de Miguel de San ... Al virrey, excusándose por no poder contribuir pecuniariamente al establecimiento de la academia y acusando recibo de la Real Orden (rúbrica). Mayo $1^{\circ}$ de 1784.

Gavets 2. 1784-1785-1786 (números del 49 al 246).

$49,50,51$. Minutas de las cartas con que se acompañaron los estatutos de la Real Academia (tres minutas). México, noviembre 23 de 1785.

52. Minuta de la carta al ỉustrísimo señor don Alonso Núñez de Aro, remitiéndo'e dos ejemplares de los estatutos y de la Real Orden para la erección de la academia.

53. Contestaciones de varios ayuntamientos y particulares a los oficios que se les pasaron acompañándo'es copia impresa de la Real Orden de erección y aprobación de la academia (un pliego conteniendo los siguientes documentos).

54. Oficio del mariscal de Castilla, marqués de Ciria. México, abril 14 de 1784 (véase número 53).

55. Oficio del marqués del Villar del Ãguila. Querétaro, abril 17 de 1784 (véase número 53 ).

56. Oficio del conde de Medina y Torres. México, abril 24 de 1784 (véase número 53 ).

57. Oficio de marqués de Rivas Cacho. México, mayo 6 de 1784 (véase número 53).

58. Oficio de fray Antonio, obispo de Guadalajara. Guadalajara, diciembre 9 de 1785 (véase número 53).

59. Oficio de fray Antonio, obispo de Michoacán. Valladolid de Michoacán, diciembre 6 de 1785 (véase número 53). 
60. Oficio de don Rafael Vasco, Castellano de Acapulco. Acapulco, 6 de diciembre de 1785 (véase número 53).

61. Oficio de fray Rafael Josef, obispo de No $\mathrm{R}^{\circ}$ de León. Ciudad de Monterrey, diciembre 23 de 1785 (véase número 53).

62. Oficio de fray Luis, obispo de Yucatán. Mérida, 20 de enero de 1786 (véase número 53).

63. Oficio de fray Antonio, obispo de Michoacán. Valladolid, diciembre 20 de 1785 (véase número 53).

64. Oficio del Cabildo de Veracruz. Veracruz (cuatro rúbricas), 20 de diciembre de 1785 (véase número 53).

65. Oficio del alcalde mayor de Etzatlán, Francisco Alonso de Escovedo. Etzatlán, 13 de diciembre de 1785 (véase número 53).

66. Oficio del alcalde mayor de la provincia de Xicayan, José González de Mesa. Tamiltepeque, provincia de Xicayan, diciembre 27 de 1785 (véase número 53).

67. Oficio de la Real Academia de San Carlos: Participa los acuerdos. y resoluciones tomadas en puntual cumplimiento de la Real Orden, reservada de 18 de noviembre de 1784 y espera que sus ref.exiones sobre varios puntos de ella, sean del soberano agrado de S. M. México, 25 de agosto de 1785 (véase número 53).

68. Oficio del alcalde mayor de Acatlán y Piaxtla, Agustín Yáñez. Acatlán, diciembre 14 de 1785 (véase número 53).

69. Oficio del alcalde mayor de Huexutla, Joseph de Cantos. Huexutla, 13 de diciembre de 1785 (véase número 53).

70. Oficio del alcalde mayor de Guadalajara, Eusegio Hernández Pareja. Guadalajara, diciembre 9 de 1785 (véase número 53).

71. Oficio del alcalde mayor de Cuernavaca, Ramón Acuña. Cuemavaca, diciembre 11 de 1785 (véase número 53 ).

72. Oficio del corregidor de Mexicalzingo, Ångel Lugo. Diciembre 6 de 1785 (véase número 53).

73. Oficio del Ayuntamiento de San Luis Potosí, S. L. P. Diciembre 26 de 1785. José de Castilla, José de la Serna, Joaquín Zeferino Zedillo, Antonio de Pagola, S. Flores de Velasco, Juan de Amrezcua (rúbricas) (véase número 53).

74. Oficio del alcalde mayor de la Antigua Veracruz, Diego Franco. Veracruz, 28 de diciembre de 1785 (véase número 53).

75. Oficio de los capellanes de la Sala Capitular de Durango. 15 de diciembre de 1785 (véase número 53). José Joaquín Valdés. Raimundo Soto Mayor, Felipe Cassador, Francisco D. Leal (rúbricas). 
76. Oficio del teniente general de la Real Justicia de Hapan, Manuel del Castiilo y Echendía, en ausencia del alcalde mayor don Pedro Fermín Noreau de Sisson. Hapan, diciembre 22 de 1785 (véase número 53).

77. Oficio del alcalde de Chiautla, Aptoval de Paz y Pinzón. Chiautla, diciembre 13 de 1785 (véase número 53).

78. Oficio del Ayuntamiento de Querétaro. Diciembre 14 de 1785 (véase número 53). Juan de Villalba y Velasque, José Martínez Moreno, Domingo de Sabarrieta, Antonio Ramón Canáliz, Pedro Antonio de Septién, Montero y Austni (?), Domingo Antonio Ferriz, Luis Rica, A. de Zárate (rúbricas).

79. Oficio del teniente general de la provincia de Theziutlán y Atempa, Manuel Pérez Toledano. Santa María Theziutlán (véase número 53). Diciembre 22 de 1785.

80. Oficio del alcalde mayor de Villalta, Pablo de Ortega. Villa Alta, 16 de diciembre de 1785 (véase número 53).

81. Oficio del alcalde de Guichiapan, F. de Barrio Junco y Esprisallo. Guichiapan, diciembre 7 de 1785 (véase número 53).

82. Oficio del gobernador de Colotlán, Rafael Amán. Aguascalientes, 17 de diciembre de 1785 (véase número 53).

83. Oficio del corregidor de Lerma. Diciembre 17 de 1785 (véase número 53) (rúbrica sin identificar).

84. Oficio de los capellanes de la Catedral de Valladolid. Diciembre 20 de 1785 (véase número 53). (En este acuse de recibo se menciona una Compañía para el Comercio de Filipinas; es posible que se trate de un error.) Leandro Blas de Echeandía, José Pérez Calasna, Manuel Nicolás de Lezo, Diego Suárez.

85. Oficio del teniente de la jurisdicción de Teococuilco, José Fernández de Molina. Diciembre 20 de 1785 (véase número 53).

86. Oficio del corregidor de Valladolid, Policarpo Dávila. Valladolid, diciembre 17 de 1785 (véase número 53).

87. Oficio del teniente general de Miahuatlán, Juan Ramón López de Sagredo. Diciembre 16 de 1785 (véase número 53).

88. Oficio del alcalde de Zimatlán, lldefonso María Sánchez Solache. Diciembre 19 de 1785 (véase número 53).

89. Oficio del alcalde de Chipila, Fernando Félix de Acosta. Diciembre 14 de 1785 (véase número 53).

90. Oficio del alcalde mayor de Teotitlán de Valle, Estevan Melgar. Diciembre 20 de 1785 (véase número 53 ). 
91. Oficio del alcalde mayor de Huatulco y Huamelula, Juan Díaz de Castro. San Pedro Huamelula, diciembre 15 de 1785 (véase número 53).

92. Oficio del justicia mayor de San Cristóbal Ecatepec, Juan Antonio Ximénez Ferenero. Diciembre 19 de 1785 (véase número 53).

93. Oficio de Miguel Páez. Real Aduana de México. Diciembre 22 de 1785 (véase número 53).

94. Oficio del alcalde mayor de Guaxuapan, José Agustín Bayo. Diciembre 16 de 1785 (véase número 53).

95. Oficio del alcalde de la Villa de Colima, Bernabé de Riaza y Velasco. Villa de Co.ima, diciembre 23 de 1785 (véase número 53).

96. Oficio del alcalde mayor de la jurisdicción de Maravatío y Villa de Citácuaro, Francisco de Larragita. San Juan Citáquaro, diciembre 13 de 1785 (véase número 53).

97. Oficio del justicia de Huayacocotia, Theodoro Alemán. Chicontepec, diciembre 11 de 1785 (véase número 53).

98. Oficio del alcalde mayor de Yahualica y Juan de Corvera. Diciembre 13 de 1785 (véase número 53).

99. Oficio del alcalde de Santo. Tuxa, José García Toro. Diciembre 10 de 1785 (véase número 53).

100. Oficio del alcalde mayor de Teposcoiula, Pedro de Quevedo. Diciembre 10 de 1785 (véase número 53 ).

101. Oficio del alcalde de Charo, Buenaventura Ximénez. Charo, diciembre 13 de 1785 (véase número 53).

102. Oficio del justicia de Coatepec, Mariano Félix de Zubínez. Diciembre 13 de 1785 (véase número 53 ).

103. Oficio del corregidor de la jurisdicción de San Pablo Guexolotitlán, Florentín Sánchez de Cañas. Diciembre 12 de 1785 (véase número 53).

104. Oficio del alcalde de Teutila, Narcizo Muñiz. Diciembre 9 de 1785 (véase número 53).

105. Oficio de los capellanes de la Catedral de Guadalajara. Diciembre 9 de 1785 (véase número 53). Nicolás López Portillo, Pedro Díaz Escandón, Pedro Miguel Quintano, Nocalás Callado Posada Platas.

106. Oficio del teniente general de Tancítaro, Cayetano García Arias de Tancítaro. Diciembre 22 de 1785 (véase número 53).

107. Oficio del Cabildo de Guadalajara. Diciembre 30 de 1785 (véase número 53). Pedro Jarero, José del Valle, Miguel de Torres y Daza. 
108. Oficio del àcalde de la Villa de San Carlos, Diego de Lassaga. Diciembre 22 de 1785 (véase número 53).

109. Oficio del alcalde de Tuxcaguesco, Juan Antonio de S. Ziprián. Tuxcaguesco, diciembre 20 de 1785 (véase número 53).

110. Oficio de los capellanes de la Sala Capitular de Durango (Durango). Diciembre 29 de 1785 (véase número 53). Alejandro Mateo y Romeo, José Díaz y Alcántara, Felipe Conttador.

111. Oficio del goberandor de Veracruz, Miguel del Corral. Veracruz, diciembre 7 de 1785 (véase número 53).

112. Oficio del teniente general de Teotitlán del Camino Real, Juan Domingo Urriza. Diciembre 7 de 1785 (véase número 53).

113. Oficio del justicia de la provincia de Cholula, Manuel Flores Cavallero, en ausencia del alcalde. Cholula, diciembre 10 de 1785 véase número 53 ).

114. Oficio del Cabildo de la ciudad de México. Noviembre 11 de 1785 (véase número 53). Francisco Antonio Crespo, Ignacio José de la Pesa y Casas, Manuel Valdés y Cienfuegos, Angel de C...N...y duendaño.

115. Oficio de Diego Panes. Perote, diciembre 8 de 1785 (véase número 53).

116. Oficio del alcalde mayor de Guanaxuato, Manuel de Tello y Somosa. Guanajuato, diciembre 7 de 1785 (véase número 53).

117. Oficio del alcalde mayor de la Villa de Carrión, Valle de Atlixco, Rafael Sánchez Carbajal. Diciembre 6 de 1785 (véase número 53).

118. Oficio del corregidor de la ciudad de Toluca, Adrián de Cerain. Diciembre 9 de 1785 (véase número 53).

119. Oficio del teniente general de Villa de León, Ignacio de Obregón, diciembre 6 de 1785 (véase número 53).

120. Oficio de Lorenzo Montoya. San Luis Potosí, diciembre 6 de 1785 (véase número 53).

121. Oficio del alcalde mayor de Tepexi de la Seda, Antonio de Molina. Diciembre 8 de 1785 (véase número 53).

122. Oficio del deán y Cabi'do de la Catedral de Antequera. Antequera, diciembre 6 de 1785 (váase número 53). Pedro Alcántara de Quintana, Aimes Mariano de Quintana, Juan de Silva y Ahuoguera.

123. Oficio de Pedro Gorrindo Palomino. Xalapa de la Feria, diciembre 8 de 1785 (véase número 53 ).

124. Oficio del alcalde mayor de Tochimilco, Rafael Contador. Diciembre 9 de 1785 (véase número 53). 
125. Oficio de Pedro Antonio de Iturbidc. San Luis de la Paz, diciembre 5 de 1785 (véase número 53).

126. Oficio del corregidor de Antequera, José Mariano de Llanos. Antequera, diciembre 6 de 1785 (véase número 53).

127. Oficio del alcalde mayor de Tlalpuxagua, Domingo Bélez de Escalante. Diciembre 9 de 1785 (véase número 53 ).

128. Oficio del gobernador de la ciudad y provincia de Tlaxcala, Francisco de Lissa. Diciembre 10 de 1785 (véase número 53).

129. Oficio de Lázaro José Figueroa Yáñez. Izúcar, diciembre 8 de 1785 (véase número 53).

130. Oficio del justicia mayor de Tixtla, Nicolás Francisco de Rivera. Diciembre 7 de 1785 (véase número 53).

131. Oficio de Manuel Cornejo. Papantla, diciembre 6 de 1785 (véase número 53).

132. Oficio del alcalde mayor de Apan, Ildefonso de Andrade y Herrera. Diciembre 10 de 1785 (véase número 53).

133. Oficio del Cabildo de Puebla de los Ångeles. Diciembre 3 de 1785 (véase número 53). Licenciado Miguel Francisco de Irigoyen, Rafael María de Gorospe, Francisco Xavier Sánchez de Pareja, Fernando Abilez.

134. Oficio de Francisco Gutiérrez de Castañeda. Temascaltepec, diciembre 3 de 1785 (véase número 53).

135. Oficio del alcalde mayor de Tulancingo, Francisco Antonio del Llano y Sierra. Diciembre 3 de 1785 (véase número 53).

136. Oficio del gobernador de Puebla, Jacobo Ugarte y Loyola. Puebla, diciembre 3 de 1785 (véase número 53).

137. Oficio del señor obispo de Puebla, Victoriano. Diciembre 3 de 1785 (véase número 53).

138. Oficio del teniente cncargado de la administración de justicia de Huexocingo, Manuel Rodríguez, Paz Romero. Diciembre 3 de 1785 (véase número 53 ).

139. Oficio del teniente general de la jurisdicción de Ixhahuaca, Francisco Durán de Velasco. Diciembre 2 de 1785 (véase número 53).

140. Oficio de Manuel Estevan Sánchez de Tagle. Zacatlán de las Manzanas. Diciembre 3 de 1785 (véase número 53).

141. Oficio de Francisco Sánchez de Vallesteros. Cuautla de Amilpas, diciembre 3 de 1785 (véase número 53).

142. Oficio del alcalde mayor de Orizaba, José Antonio de Arssu y Arcaya. Diciembre 7 de 1785 (véase número 53). 
143. Oficio del aicalde mayor de Tula, Francisco González de Cossío. Diciembre 9 de 1785 (véase número 53).

144. Oficio de Juan de Villalva y Velásquez. Querétaro, diciembre 9 de 1785 (véase número 53).

145. Oficio de don Fernando José Mangino a don José de Gálvez (copia). Informa que se cumplieron sus disposiciones acerca de la junta de la academia, declarando la perpetuidad de los consiliarios, el método con que deben proponerse y el orden de precedencia en los asientos. 3 de enero de 1785 .

146. Oficio de don Fernando José Mangino a don José de Gálvez (copia), informándole que la Real Academia compró el solar de Nip pantongo, en 30 mil pesos, para construir su edificio, en la calle de San Andrés, inmediata a la Alameda. Le adjunta el plano del referido terreno para que hagan el proyecto en la Academia de San Fernando. México, 27 de enero de 1785.

147. Oficio de la Real Audiencia Gobernadora a don Fernando José Mangino, participando haber pasado órdenes a los oficiales reales de estas cajas y director general de temporalidades para que satisfagan respectivamente los $\$ 130$ de la real dotación correspondiente a un año vencido. México, 31 de enero de 1785. Vicente de Herrera, Miguel Calixto de Aredo, Ruperto Vicente de Luyando (rúbricas).

148. Renuncia que hizo el doctor don José Ignacio Bartolache del empleo de secretario de la Real Academia, 1785 (falta el documento, sólo está la primera hoja con el membrete y la siguiente copia): Admisión de la renuncia (junta de 11 de agosto) y acuerdo para condecorarle con el distintivo de académico de honor. México, 2 de noviembre de 1785 .

148 a. Contestación de don José Ignacio Bartolache al oficio que se le pasó participándole el grado de académico de honor, 1785 (Hoja suelta sin el oficio aludido).

149. Representación del director general don Gerónimo Antonio Gil, sobre gratificaciones a los tenientes y demás que han servido en la academia. Informa sobre las personas que ha destinado como profesores y ayudantes e indica que se necesitan directores de escultura y pintura. Menciona a las siguientes personas: Francisco $\mathrm{Ca}$ plera, José Alcíbar, Rafael Gutiérrez, Andrés López, Juan Sáenz, Mariano Vásquez, Manuel Serna y Manuel García, profesores de pintura; Santiago Sandoval, escultor; Miguel Constansó y José Ortiz, profesor y ayudante en arquitectura y geometría; Luis Gómez, Alonso Ximénez Caro, Antonio Cervantes, Pedro Berdugo, José 
Esteve y Manuel Gómez de Paz, en diversos empleos. Abril de 1785.

150. Oficio del viceprotector a don Miguel Páez de la Cadena, superintendente de la Real Aduana sobre la alcabala que causó la compra del sitio de Nilpantongo, que compró en subasta pública al mayorazgo don Juan Velázquez de la Cadena en $\$ 30.000$ (copia). México, agosto 23 de 1785.

151. Oficio del conde de Gálvez a don José de Gálvez, solicitando la exención del Real Decreto de Aicabalas que causó en su venta el terreno destinado para el edificio de la Real Academia, llamado Nilpantongo (copia). 25 de agosto de 1785.

152. Oficio de don Fernando José Mangino a don José de Gálvez, adjuntándole los dibujos para las medallas de la academia, trabajado por don Gerónimo Antonio Gil, para que elija (copia del oficio). México, 26 de octubre de 1785.

153, 154. Representación del arquitecto don José Damián Ortiz sobre el modo de beneficiar el yeso y de usarlo en las fábricas, e informe que hicieron en el asunto don Miguel Constansó y don Gerónimo Antonio Gil. México, octubre 24 de 1785 (rúbricas).

155. Indice de las representaciones que la Real Academia hace a S.M. por la vía reserva (copia).

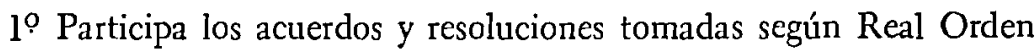
de 18 de noviembre.

29 Participa la elección de don Miguel Constansó para director. 30 Solicita la exención de la alcabala por el terreno que compró a Juan Velázquez.

40 Participa haber señalado gratificación al director don Gerónimo Antonio Gil.

50 Participa el nombramiento de secretario en favor de don Antonio Piñeiro, y en lugar de don José Ignacio Bartolache a quien se designó académico de honor. México, 25 de agosto de 1785.

156. Representaciones del director don Gerónimo Antonio Gil, sobre arreg'o de la academia, sueldos y otros puntos (pliego conteniendo los siguientes documentos: 157, 158, 159 y 160). 1785 .

157. Representación del director don Gerónimo Antonio Gil sobre los perjuicios que ocasionan tratantes en los ramos de pintura, escultura, etcétera, que tienen obradores públicos, proponiendo al mismo tiempo el medio de evitarlos. México, 28 de marzo de 1783 (rúbricas). 
158. Representación del director don Gerónimo Antonio Gil sobre varios asuntos relativos al mejor gobierno de la academia. Menciona a las siguientes personas: Diego Mestre y Pardo, José María Vásquez, los hijos de Sandoval, Estevan Gonzáiez, Fernando Loazes, Agustín Zerezo, Juan Marchena, Manuel García, Mariano del Águila, Juan Ignacio Guerrero, José Luis Marenco, Mariano Espinosa de los Monteros y Francisco Suelmo. México, agosto 5 de 1784 (rúbricas).

159. Oficio de don Gerónimo Antonio Gil, acompañando un plan con datos sobre los puestos y sueldos de las Reales Academias de San Fernando de Madrid y San Carlos de Valencia, para que de acuerdo con ellas se instruya a los individuos de las clases acerca de las condiciones. Abril 14 de 1785 (copia).

160. Informe y relación de antecedentes sobre matrices y caracteres de imprenta. Pide se instale una imprenta con caracteres y prensas nuevas (copia sin firma ni fecha. El original debió estar dirigido al virrey). 1785 .

161. Legajo conteniendo documentos relativos a las donaciones en efectivo, designadas a la Real Academia. Veracruz, San Miguel el Grande y Querétaro (este legajo contiene los documentos numerados del 162 al 177 inclusive).

162. Oficio del Cabi'do de la Villa de San Miguel el Grande al secretario don Antonio Piñeiro. Incluye libranza por $\$ 50.00$ a favor de don Fernando José Mangino. Abril 19 de 1785. Pedro Ximenes de Ocón, Bàas Mariano de Santo, Francisco Mariscal (rúbricas).

163. Oficio del Cabildo de Querétaro al secretario don Antonio Piñeiro, adjuntando libranza por $\$ 100.00$ a favor de don Fernando José Mangino. Abril 19 de 1785. Pedro Vidal, José Martínez Moreno, Domingo Labarrieta (rúbricas).

164. Oficio del Cabildo de Veracruz al secretario don Antonio Piñeiro, adjuntándole libranza por $\$ 200.00$, a favor de don Fernando José Mangino. Veracruz, abril 20 de 1785. Adrián Félix Troncoso (rúbrica).

165. Carta de Rafael José Facio a don Antonio Piñeiro, avisándole que en su calidad de Alférez Real del Ayuntamiento de Veracruz, da órdenes a don Ignacio de Azoitia de México para que ponga en manos del señor don Fernando José Mangino los $\$ 200.00$ con que contribuye cse ayuntamiento. Veracruz, mayo 10 de 1886 (rúbrica).

166. Oficio de Rafael José Facio, Real Alférez del Ayuntamiento de Veracruz, a don Antonio Piñeiro, adjuntándole una libranza por $\$ 200.00$ contra don Juan José Maurimo de México. Veracruz, enero 24 de 1787 (rúbrica). Al margen: Contestada el 28 de febrero. 
167. Oficio de Pedro Moreno, del Ayuntamiento de Veracruz, a don Antonio Piñeiro, enviándole una libranza por $\$ 200.00$ girada por clon Pablo Frayle y señorita María contra don Manuel de Urquiaga. Veracruz, marzo 24 de 1792 (rúbrica). Al margen: Contestada el 4 de abril.

168. Oficio del Cabildo de Veracruz a don Antonio Piñeiro, avisándole que el mes de abril le enviaron una libranza dada por don Miguel de Lizardi contra don Juan Díaz González. Veracruz, mayo 8 de 1794. Antonio de Cárdenas, Adrián Féliz Troncoso, Pedro Moreno, Manuel Antonio Fernando Icauna, José Antúnez, Tomás de Aguirre, Domingo Lagoa y de Miranda (rúbricas).

169. Libranza contra don Diego Eznal cle Veracruz, por $\$ 200.00$ a favor de la Real Academia (copia). México a Veracruz, junio de 1795.

170. Oficio del secretario don Antonio Piñeiro del Cabildo de V. C. informándole que ha girado una libranza contra don Diego Eznal de ésa por $\$ 200.00$ (copia). México, septiembre 16 de 1795.

171. Oficio de don Antonio Piñeiro al secretario del Ayuntamiento de Veracruz, aclarando algunas cuentas sobre la donación a la Real Academia (copia). México, diciembre 6 de 1809.

172. Oficio de don José Manzano de Almanza, del Ayuntamiento de Veracruz, a don Antonio Piñeiro, aclarando algunas cuentas relativas a la dotación de la Real Academia. Veracruz, diciembre 27 de 1809.

173. Minuta del oficio de don Antonio Piñeiro al Ayuntamiento de Veracruz, acusando recibo de una libranza por $\$ 180.00$ contra don Tomás Ramón de Ibarrola. Contestación al oficio de 27 de diciembre de 1809 (sin fecha ni firma).

174. Oficio de Ángel González, del Ayuntamiento de Veracruz, a don Antonio Piñeiro, adjuntándole una libranza por $\$ 200.00$ contra don Martín Angel de Michaus. Veracruz, agosto 7 de 1811 (rúbricas).

175. Minuta del oficio de don Antonio Piñeiro a don Angel González, acusando recibo de la libranza de la ciudad de Veracruz (su oficio de agosto 7). México, agosto 17 de 1811.

176. Oficio de don Pedro del Paso y Troncoso, del Ayuntamiento de Veracruz, a don Antonio Piñeiro, advirtiéndole que gire a principios de cada año contra el Cabildo de la ciudad por los $\$ 200.00$ con que contribuyen para la subsistencia de la Real Academia. Veracruz, febrero 12 de 1812 (rúbrica). 
177. Minuta del oficio de don Antonio Piñeiro a don Pedro del Paso y Troncoso, acusándole recibo de su anterior de 12 de febrero. México, marzo 7 de 1812.

177 a. Lista de premios (impreso). Octubre 30 de 1785.

178. Legajo conteniendo contestaciones de varios tribunales y otros sujetos sobre el recibo de los estatutos (conticne los documentos enumerados a continuación, del 179 al 192, inclusive).

179. Oficio del alcalde mayor de Pánuco y Tampico, Manuel Vásquez. Tenayuca, enero 1 de 1786 (rúbrica). Véanse números 53 y 178.

180. Oficio del Ayuntamiento de Antequera al virrey (véanse números 53 y 178). Antequera, enero 1 de 1786. José Mariano de Llano, Joaquín Ximénez Bohorques, Francisco Juan Quintana, Diego Villasante, José Alonso Romero.

181. Oficio de Manuel Barreto al virrey, Sayula, encro 2 dc 1786 (rúbrica). Véanse números 53 y 178.

182. Oficio del Ayuntamiento de Tlaxcala al virrey (véase númcros 53 y 178). Tlaxcala, enero 14 de 1786. Francisco Lilia, F. Pćrez de Herrera, José Esteban cle Escobar, Martín Antonio Sánchez y Torres, Julio Simón Sarmiento, José Mariano Sánchez de Torres, Tomás Francisco Mendiola, Matías Ruscerio (11 firmas, las demás sin identificar).

183. Oficio del alcalde mayor de Guauchinango, Sebastián Ortiz (véanse números 53 y 178). Enero 3 de 1786 (rúbrica).

184. Oficio de Juan Antonio Pisón al virrey (véanse números 53 y 178). San Miguel el Grande, enero 3 de 1786 (rúbrica).

185. Oficio del Ayuntamiento de Mérida de Yucatán al virrey (véanse números 53 y 178). Encio 21 de 1786. Agustín Carrillo Pimentel, Pedro Jáuregui Brunes, Lorenzo A. Mandicutt, José Joaquín Charón, Bernardo Boamonde (rúbricas).

186. Oficio de Francisco de Amusquiban al virrey (véanse números 53 y 178). Tacotalpa, enero 4 de 1786 (rúbricas).

187. Oficio de Juan Navarro al virrey. México (véanse números 53 y 178), febrero 22 de 1786 (rúbrica).

188. Oficio del alcalde mayor de Mérida de Yucatán, Josć Ximénez y Zevallos. Mérida (véanse números 53 y 178), enero 9 de 1786 (rúbrica).

189. Oficio del gobernador del Presidio del Carmen, Josć de Casasola, al virrey (véanse números 53 y 178), enero 24 de 1786 (rúbrica). 
190. Oficio del alcalde mayor de Cuitzeo de la Laguna, Pedro Pérez de Zadaire, al virrey (véanse números 53 y 178), febrero 5 de 1786 (rúbrica).

191. Oficio del Ayuntamiento de Chihuahua al virrey (véanse números 53 y 178). Fnero 9 de 1786 (rúbrica).

192. Oficio de José Manuel Vayeto al virrey (véanse números 53 y 178). Chietla, marzo 6 de 1786 (rúbrica).

193. Legajo conteniendo varios oficios del Ayuntamiento enviando libranzas para la subsistencia de la academia. 1786, 1787, 1789 (contiene documentos numerados del 194 al 201, inclusive).

194. Oficio de José Vicente de los Ríos, al secretario don Antonio Piñeiro, adjuntándole libranza por $\$ 200.00$. Guanajuato, mayo 30 de 1786 (rúbrica).

195. Oficio del Cabildo de la Villa de San Miguel el Grande: adjunta libranza por \$ 50.00 dada por el regidor Mariano Loreto de la Canal contra don Antonio Yermo, de México. San Miguel el Grande, enero 25 de 1787. Juan Antonio Muñoz de Pisón, José Mariano Loreto de la Canal, Pedro de Vidaonda, Nicolás de Robles.

196. Oficio de Juan Antonio de Cora, del Ayuntamiento de Orizaba a don Antonio Piñeiro, sobre el asunto de que se libraran anualmentc $\$ 15.00$. Orizaba, enero 17 de 1787 (rúbrica).

197. Oficio de Pedro Antonio de Septién, Montero y Austri, del Ayuntamiento de Querétaro, a don Antonio Piñeiro, adjuntándole libranza por $\$ 100.00$ dada por don Antonio Lorenzo de Horge, contra don Juan Felipe Mungarrieta, de México. Querétaro, enero 20 de 1787 (rúbrica).

198. Oficio del Cabildo de Guanajuato a don Antonio Piñeiro. Se excusa de no remitir los $\$ 200.00$ de subsidio, pero promete hacerlo el mes siguiente. Guanajuato, enero 24 de 1787. Antonio Clemente de Arostegui, Juan Vicente Alemán, Josć Marañón, Miguel de Rivera S. Lorenzo, José Hernández Chico.

199. Oficio de Pedro Antonio de Septién Montero y Austri, a don Antonio Piñeiro, enterado del acuse de recibo de una libranza de \$ 100.00. Querétaro, marzo 23 de 1787 (rúbrica).

200. Oficio del Cabildo de Guanajuato a don Antonio Piñeiro, adjuntándole libranza por \$200.00. Guanajuato, abril 30 de 1788. Andrés Sagás (rúbrica).

201. Minuta de los oficios dirigidos a los Ayuntamientos de Veracruz, Querétaro, Guanajuato, Orizaba y Córdoba, suplicando se sirvan remitir libranzas por valor del subsidio de la academia. Abril 23 de 1788. 
202. Oficio al director general de la academia don Gerónimo Antonio Gil, remitiéndole copia certificada de la Real Orden de 12 de abril último y de la nota que la acompaña para su cumplimiento. Septiembre 18 de 1786 ( $\sin$ firma).

203. Oficio del marqués de Sonora al virrey. Dice que los dibujos que hizo don Gerónimo Antonio Gil para las medallas de premios, aunque buenos, no están de acuerdo con el artículo 26 de los estatutos. Da instrucciones para pesos, diámetros, asuntos, etcétera (véase número 204). Madrid, abril 12 de 1786 (rúbrica).

204. Nota con diez temas para medallas (sin fecha, rúbrica del marqués de Sonora, véase número 203).

205. Oficio del marqués de Sonora al virrey. Informa de la Real aprobación del nombramiento de don Antonio Piñeiro, como secretario de la academia en lugar de don José Ignacio Bartolache, y le asigna $\$ 1,500.00$ anuales de sueldo a partir del 11 de agosto de 1785 . Madrid, abril 12 de 1786 (rúbrica).

206. Oficio del marqués de Sonora al virrey. Contesta de enterado de que el doctor 'José Ignacio Bartolache renunció de su puesto de secretario de la academia y de que se le ha nombrado Académico de Honor. Da cuenta de la Real aprobación. Madrid, abril 12 de 1786 (rúbrica).

207. Oficio del marqués de Sonora al virrey. Contesta de enterado e informa de la Real aprobación para la partida de sueldos. $\$ 1,500$ para el puesto de secretario. $\$ 800.00$ para el puesto de conserje. 4 reales diarios a cada portero. 4 reales diarios a cada modelo. 4 reales diarios a cada pensionado (eran seis). Madrid, 12 de abril de 1786 (rúbrica).

208. Oficio del marqués de Sonora al virrey. Contesta de enterado por haber recibido las listas de los libros y demás objetos que trajo a Nueva España don Gerónimo Antonio Gil y los que después adquirió la academia. Madrid, abril 12 de 1786 (rúbrica).

209. Oficio del marqués de Sonora al virrey. Contesta de enterado de $\$ 1,000$ anuales de sobresueldo asignados a don Gerónimo Antonio Gil y advierte que se aprueba la disposición para este director, mas no para los que le sucedan. Estos deberán ser a la vez directores particulares de grabado de medallas en la academia sin sueldo. El rey asignó como excepción otros $\$ 500.00$ anuales a Gil por enseñar el grabado de medallas. Madrid, abril 12 de 1786 (rúbrica).

210. Oficio del marqués de Sonora al virrey. Contesta de enterado de la petición que se hizo sobre libros, útiles y copias de las grandes estatuas que había en la Academia de San Fernando. Recomienda 
a la junta reduzca sus pretensiones a lo más preciso. Pide se remitan a Cádiz de 12 a 16,000 pesos, de los fondos de la academia para la compra de útiles. Madrid, abril 12 de 1786 (rúbrica).

211. Oficio del marqués de Sonora al virrey. Contesta de enterado que se necesita un maestro director de pintura con sueldo de $\$ 2,000$ anuales y un segundo con $\$ 1,500$. Además un director de escultura, otro de arquitectura y otro más de grabado, cada uno con $\$ 2,000$ anuales. Informa que se ha decidido que el sueldo del segundo de pintura sea también de $\$ 2,000$ que $\mathrm{S}$. M. en atención a la súplica ha nombrado primer director de pintura a don Ginés de Andrés de Aguirre y para segundo a don Cosme de Acuña; para director de cscultura a don Manuel Arias; para director de arquitectura a con Antonio González Velásquez y para director de grabado de estampas a don Fernando Selma. Madrid, abril 12 de 1786 (rúbricas).

212. Oficio del marqués de Sonora al virrey. Contesta de enterado de la petición para que los premios de $\$ 200$ bimcstrales se reduzcan a trimestrales a título de "por ahora". S. M. aprobó lo dispuesto por la junta, con caritativas recomendaciones. Madrid, abril 12 de 1786 (rúbrica).

213. Oficio del marqués de Sonora al virrey. Informa que de los cinco profesores nombrados para la academia, saldrán de Cádiz en la primera oportunidad don Ginés de Andrés y Aguirre, don Cosme de Acuña, don Manuel de Arias y don Antonio González Velásquez. Sus sueldos deberían correr desde el día que verificasen su embarco. Se refiere a otros detalles. Madrid, abril 18 de 1786 (rúbrica).

214. Oficio del marqués de Sonora al virrey. Contesta e informa haber recibido los 50 ejemplares de los estatutos y de que el rey se ha enterado de la formal apertura y distribución de premios de la academia (hecha el 4 de noviembre de 1785). Aranjuez, abril 22 de 1786 (rúbrica).

215. Certificación del día en que se embarcaron en Cádiz los directores don Andrés Ginés de Aguirre, don Cosme de Acuña, don José Arias y don Antonio González Velásquez (legajo conteniendo los documentos números 216 y 217). 1786.

216. Certificación del escribano del navío de Nuestra Sefiora del Rosario y San Francisco de Asís, del embarque de los señores don Ginés de Andrés y Aguirre, don Cosme de Acuña, don Manuel José de Arias y don Antonio González Velásquez, el día 24 de junio de 1786, a las 10.30 de la mañana con destino a Veracruz. Junio 24 de 1786. Pedro Fernández Guerra (rúbrica). Certificación de la copia. Julio 
$1^{\circ}$ de 1786. Felipe Romano, Gerónimo Sánchez Bernal (rúbricas). Otra certificación finmada por Anselmo López, Rafael Díaz y Calixto Sans (rúbricas).

217. Oficio de don Bartolomé de Ortega Montenegro del Consejo de S. M. al superintendente de la Real Casa de Moneda de México. Adjunta testimonio del día en que se embarcaron los profesores mencionados. Cádiz, julio 18 de 1786 (rúbrica).

218. Oficio de los ministros de la Real Hacienda relativo al dinero suplido en Cádiz para los directores don Andrés Ginés de Aguirre y don Antonio González Velásquez con la respuesta del señor presidente (legajo conteniendo los documentos números 219 y 220). 1786.

219. Oficio de los ministros de la Real Hacienda a las cajas de esta capital, al superintendente de la Casa de Moneda, don Fernando José Mangino, avisándole de las cantidades que se les anticiparon a los directores don Ginés Andrés Aguirre, $\$ 3,500$ y a don Antonio González Velásquez, $\$ 3,300$ para que esas cantidadcs se reintegren a las Reales Cajas, descontándolas de sus sueldos. México, noviembre 3 de 1786. Luis Gutiérrez, Francisco de Sales Carrillo (rúbricas).

220. Oficio del marqués de Sonora a los ministros de la Caj̣a Matriz. Informa que según lo dispuesto, se les descontará a los directores, Aguirre y Velásquez el anticipo que se les dio "dejándoles lo necesario para su subsistencia". México, diciembre $1^{9}$ de 1786 (copia).

221. Poder general para cobranzas que otorgaron los señores presidente y consiliarios de la Real Academia de San Carlos de Nueva España, al capitán don Antonio Piñeyro, secretario de la misma academia (copia certificada por José Antonio Morales). México, diciembre 30 dc 1786. Firmaron: José Soto, Antonio Calixto Morales y Joaquín Casarín, como testigos. Fernando Mangino Román de Posada, Francisco Antonio Crespo, José Angel de Cuevas, Aguirre y Abendaño, Antonio Barroso y Torrubia, Antonio de Bassoco, el Mariscal de Castilla, marqués de Ciria. El marqués de San Miguel de Aguayo.

222. José Cleto Nepomuceno Salcedo, español, pobre, natural de esta ciudad huérfano de padre, sacó algunos premios y asistió a la academia de tres años y medio a esta parte. Presenta fe de bautismo (escultura). 1786 (legajo conteniendo los documentos números $223,224,225)$.

223. Solicitud que presenta don José Cleto Juan Nepomuceno Salcedo, para ser admitido como alumno pensionado del ramo de cscultura. 
Declara haber sido discípulo de don Manuel Tolsá (sic) (rúbrica). Sin fecha (1786).

224. Fe de Bautismo de José Cleto Juan Nepomuceno Salcedo. México, agosto 10 de 1786. Nicolás Calvo, presbítero (rúbrica).

225. Nueva solicitud de José Clcto Salcedo para ser admitido como pensionado en el ramo de escultura (por haber traspapelado la anterior y la fe de bautismo). Ratifica que es notoria su pobreza y que de su habilidad dará informes su "Director D. Manuel Tolsá, como igualmente el tiempo que en su compañía y casa he estado".

226. Memorial de don José Molina y Garrido presentando varios dibujos de su mano a la academia (legajo conteniendo los documentos números 227 a 231), 1786.

227. Oficio de don José de Molina y Garrido, discípulo de la Real Academia, presentando cuatro ejemplares de grabados impresos en distintas clases de papel, como muestra de su aplicación en el dibujo, grabado e impresión, y para que se aprovechen o rechacen. México, enero 11 de 1786 (rúbrica, véanse números 228, 229, 230 y 231).

228. Carpeta de papel conteniendo los dibujos números 229, 230 y 231 "Para la Rl. Academia de San Carlos de Nueva España".

229, 230, 231. Grabados de muy buena técnica. En cada hoja dos viñetas: una representa* un hombre encaramado en un árbol y la otra una alegoría de las Bellas Letras.

232. Legajo conteniendo solicitudes de profesores y de pensionados, 1786 (contiene los números 233 al 241).

233. Solicitud de don Antonio Gonzálcz Velázquez, director de arquitectura, pidiendo cuatro delineantes y algunos útiles, así como que se nombre subteniente a don José Ortiz (rúbrica). Al margen el acuerdo de la junta. Se negó las pretensiones y sólo se concedió lo respectivo a útiles. Octubre 10 de 1780 (rúbrica).

234. Solicitud de don Cosme de Acuña y Troncoso pidiendo útiles para hacer las colecciones de los retratos del marqués de Sonora y para el estudio de los pensionados de pintura. Sin fecha (1786?, rúbrica).

235. Un dibujo, sin letrero alguno de una varilla con puntera afilada (a lápiz). Sin fecha (1786?).

236. Solicitud de útiles por el dircctor don José Arias (rúbrica). Sin fecha (1786?). 
237. Oficio de don José Damián Ortiz. Dice que ha desempeñado varias obras rclativas a su profesión (arquitectura) y que ha asistido al establecimiento de la academia en donde desempeñaba el pucsto de ayudante del director y capitán de ingenieros don Miguel de Constans 6 , en la sala de geometría. Pide se le nombre tasador de las obras de arquitectura (rúbrica). Al margen el acuerdo de la junta que oportunamente se atenderá su mérito. Octubre 10 de 1786 (rúbrica).

238. Solicitud de Josć Ignacio de la Cerda, capitán de la Sexta Compañía del Batallón de Pardos de esta capital y profesor del arte de la pintura, para que se le permita establecer una casa de instrucción (escuela de arte) en la ciudad de Veracruz (rúbrica). Nota en un volante: "que se dé cuenta sobre esto al Sr. Gobernador en Veracruz en junta ordinaria". Octubre 3 de 1786.

239. Solicitud de don Cosme de Acuña y Troncoso, pidiendo se rectifique en su nombramiento su calidad de Académico de Mérito de la Academia de San Fernando de Madrid, pues tal título se omitió y suplica se haga la correspondiente nota en los libros de la academia. México, octubre 4 de 1786 (rúbrica).

240. Solicitud de con Bernardo Gil, hijo de don Gerónimo Antonio para que en atención a sus méritos y a los de su padre, se le nombre conserje (rúbrica). México, agosto 20 de 1786. Al margen: "Resuelto en junta de septiembre 2 de 1786" (rúbrica).

241. Carta de don Bernardo Gil a la excelentísima señora marquesa de Sonora de cuyas hijas era maestro de dibujo, para que interceda con el virrey y el señor Mangino en relación con su solicitud para obtener el puesto de conserje. México, agosto 20 de 1786 (rúbrica).

242. Inventario de todos los útiles de la Real Academia de San Carlos formado en diciembre de 1786. 11 fojas. José Esteve (rúbrica).

243. Memoriales de varios profesores y dependientes de la academia. Legajo que contiene los siguientes documentos números 244,245 y 246. 1783.

244. Francisco Reales solicita ser admitido en la academia para estudiar dibujo. Sin fecha (1783?).

245. Tomás de Suria, José Esteve y Bernardo Gil solicitan se les gratifique por horas extraordinarias de trabajo (rúbricas). Al margen: Acuerdo asignándoles gratificaciones. 30 de octubre de 1783 .

246. José Mariano Saravia y José Joaquín Rodríguez, que servían de modelos, piden se les aumente el sueldo (tenían cuatro reales los días que les tocaba turno) (rúbricas). Julio 6 de 1784. Al margen: Acuerdo. Se les mandó pagar cuatro reales diarios. 
Gaveta 3. 1787-1788 (números del 247 al 445).

247. Impreso. Lista de la distribución de premios y extraordinarios. Agosto 22 de 1787.

248. Copias de: Acuerdo para que los jóvenes pensionados que estaban al cuidado de don Andrés Ginés de Aguirre pasen al de don Cosme de Acuña. Octubre 26 de 1787.

Orden para que los jóvenes pensionados pasen a instruirse con don Cosme de Acuña. Octubre 26 de 1787.

Oficio de la junta a don Jerónimo Antonio Gil informándole del acuerdo anterior y previniéndolo de que cuide de la puntual asistencia de los dircctores y del cumplimiento de sus deberes. Octubre 26 de 1787.

249. Oficio de la junta (a don Jerónimo Antonio Gil) señalando el horario de los señores directores (copia).

Abril 15 de 1787.

250. Oficio del contador de temporalidades, don Bernardo Fajardo y Cobarrubias al capitán don Antonio Piñeiro participando haberse determinado que los 4 pesos de la Real dotación asignados a los señores de dicho ramo se paguen por oficiales Reales de estas cajas. Diciembre 15 de 1787 (rúbrica).

251. Carta de don Pedro José Márquez de Ochoa, al presidente de la junta, diciendo que envía un rollo con dos estampas de Rafael, como obsequio a la academia. Ofrece una traducción suya del libro de Fernando Galli de Bibicra Boloñes (xvII). Roma, agosto $1^{\text {o }}$ 1787 (rúbrica).

252. Indice de Reales Órdenes. 23 en total, de 1783 a 1787.

253. Impreso. Lista de premios. Enero 17 de 1788.

254. Oficio de don Manuel Antonio Flores a la junta, transcribiendo un oficio de don Antonio Polier en que se da aviso de que "se han entregado, por orden del rey, a don Joaquín Fabregat, que pasa a esa ciudad con el empleo de Director de Grabado de la Real Academia de Sn. Carlos quince mil reales de vellón con calidad de reintegro". México, marzo 3 de 1788 (rúbrica).

255. Oficio de don Manuel Flores a la junta, transcribiendo la Real Orden de 21 de noviembre de 1787, que le envió don Antonio Porlier en que se nombra a don Joaquín Fabregat para el empleo del grabado en láminas de la Real Academia de San Carlos, con un sueldo de dos mil pesos anuales. México (rúbrica). Marzo 3 de 1788 . 
256. Lista de "Tres escrituras". 1788. Una fianza de don Manuel Orcasitas, otorgándose por fiador del conserje don Diego Maestre.

1791. La de arrendamiento de la casa que fue del Amor de Dios otorgada por el mayordomo del Hospital de San Andrés.

1793. Y la de venta del sitio y solar que poseía la academia frente a San Andrés llamado Milpantongo.

257. Copia certificada por don Mariano Muñoz de la fianza otorgada por don Manuel Orcasitas en favor del conserje don Dicgo Maestre (rúbrica). Mćxico, octubre 8 de 1788.

258. Villa de Córdoba. Legajo conteniendo los documentos números 259 y 260 .

259. Oficio de don Francisco Pérez a don Antonio Piñeiro, avisándole que están listos los 15 pesos con que anualmente contribuye el Cabildo al sostenimiento de la academia y que los enviará tan pronto como sea posible (rúbrica). Córdoba, enero 24 de 1787.

260. Oficio de don Bernardino de a don Antonio Piñeiro avisándole que don Francisco Benito Posa pondría en su poder los quince pesos con que anualmente el Cabildo contribuye al sostenimiento de la academia (rúbrica). Córcloba, mayo 7 de 1788.

261. Oficio del señor presidente don Fernando José Mangino al excelentísimo señor viceprotector don Manuel Antonio Flores, virrey de Nueva España, informándole sobre el estado de los fondos de la academia, con motivo de su próxima restitución a España, acompañándole una nota de cuentas (copia). México, febrero 15 de 1788.

262. Instancia de don José Damián Ortiz, maestro mayor de esta nuestra ciudad para que se le admita por Académico de Mćrito, con el informe que hizo en el asunto el teniente coronel de ingenieros don Miguel Constansó. Legajo conteniendo los documentos números 263 y 264.1788.

263. Solicitud de don José Damián Ortiz, maestro mayor de esta nuestra ciudad y de la Santa Iglesia Catedral para ser admitido por Académico de Mérito y presentando "plano, corte y fachada principal para reedificio de la antigua iglesia de Tulanzingo", teniendo en cuenta de que se sirve "de sus paredes". Asimismo presentó los documentos de limpieza (rúbrica). Arriba: Acuerdo de que la solicitud y los planos pasen a don $\mathrm{M}$. Constansó para que informe. Posada (rúbrica). Diciembre 12 de 1788.

264. Informe de don Miguel Constansó sobre el proyecto de reedificación de la iglesia de Tulancingo. Describe los planos y dibujos y, salvo un detalle del coro, declara que todo tiene "adecuadas pro- 
porciones y juiciosa composición", y que "La aplicación del sujeto me es conocida; y su idoneidad lo hacen acreedor a la distinción a que aspira" (José Damián Ortiz) (rúbrica). México, septiembre 15 de 1788.

265. Instancia de don Esteban González para que se le admita por Académico de Mérito en el ramo de arquitectura, con el informe que hizo en el asunto el teniente coronel de ingenieros don Miguel Constansó. 1788. Legajo conteniendo la solicitud. Documento número 266 e informe.

266. Instancia de Esteban González. Septiembre 6 de 1788. México (rúbrica). Al margen el acuerdo de la junta de 21 de agosto, para que pase el asunto al ingeniero Constansó, para informar. Informe del ingeniero don Miguel Constansó sobre el proyecto de una aduana, presentado por Esteban González. Favorable (rúbrica). México, septiembre 15 de 1788.

267. Sobre haber admitido por Académico de Mérito a don José Damián Ortiz y a don Esteban González Supernumerario. 1788. Legajo conteniendo los documentos números 268 y 269.

268. Oficio del presidente de la junta al virrey, don Manuel Antonio Flores, participándole haber admitido por Académicos de Mérito a don José Damián Ortiz y a don Esteban González (el primero por unanimidad y el segundo por mayoría). Diciembre 6 de 1788. México (copia).

269. Oficio del virrey Flores al presidente de la Real Academia, enterado de que han sido admitidos como Académicos don José Damián Ortiz y don Esteban González y dando su aprobación para que se disponga de los puestos que les corresponde. Flores y Antonio Bonilla (rúbrica). México, diciembre 10 de 1788.

270. Oficio del excelentísimo señor viceprotector, participando haber nombrado para segundo clavero del arca de caudales al señor consiliario don José Angel Aguirre. 1788. Legajo conteniendo los documentos números 271 y 272 .

271. Oficio del presidente de la Real Academia al virrey, proponiéndole nombre la persona que como consiliario, guarde la segunda llave (de las tres) del arca de caudales de la academia (copia). Septiembre 25 de 1788. México.

272. Oficio del virrey Flores al presidente de la Real Academia, enterado de la consulta anterior le participa haber nombrado para guardar la segunda llave del arca de caudales de la academia al consiliario 
más antiguo. Flores y Fernando de Córdoba (rúbricas). México, octubre 3 de 1788 .

273. Representación del señor presidente de la Real Academia para la traslación del arca de caudalcs a las Caxas Reales de esta ciudad. 1788. Legajo conteniendo los documentos números 274 y 275.

274. Oficio del presidente de la Real Academia al virrey Flores, avisándole que está lista el arca de caudales para que se traslade a las Cajas Reales de la ciudad y rogándole se sirva disponer que pasen los caudales de la tesorería de la Casa de Moneda al Arca de tres llaves (copia). México, julio 5 de 1788.

275. Oficio del virrey Flores al presidente de la Real Academia, avisándole que ya dispuso que se trasladen los caudales al Arca de tres llaves (rúbrica). México, julio 10 de 1788.

276. Memorial de los profesores que fueron correctores del dibujo, pidiendo se les dé alguna gratificación por el tiempo quc han servido por cinco años. 1788. Legajo conteniendo el documento número 277.

277. Memorial de los profesores para que se les certifique que por cinco años han trabajado horas extra corrigiendo dibujos. Rúbricas: Mariano Vásquez, Andrés López, Juan de Sáenz, Manuel Serna, Manue] García, Rafael Iñaquí y N. de Gutiérrez (sin fecha). Al margen: Se dio la certificación..." y México, mayor 17 de 1788.

278. Representación de la junta superior de gobierno al excelentísimo señor viceprotector sobre que se remitan a España los caudales que por cuenta de la Real Hacienda se suplieron a los directores para su transporte a este reino. 1788. Legajo conteniendo el documento número 279.

279. Oficio de la junta superior de gobierno al virrey Flores, dando cuenta de las cantidades suplidas en Madrid por los cuatro directores de la academia y avisándole que acordaron se remitan a España por mano del consiliario don Antonio de Basoco. México, mayo 17 de 1788. Ramón de Posada, Ångel de Cuevas Aguirre y Avendaño, Antonio Basoco y Torrubia, marqués de Ciria, marqués de San Miguel de Aguayo (rúbricas).

280. Instancia de los directores: don Ginés de Andrés Aguirre, don Cosme de Acuña y don Antonio González Velázquez, para que se les releve de asistir de día a ella, con lo demás que expresa, y la Real Orden expedida en cl asunto. 1788. Legajo conteniendo los documentos números 281 al 291 inclusive.

281. Oficio de los directores, don Ginés de Andrés Aguirre, don Cosme de Acuña y Troncoso y don Antonio González Velázquez, expo- 
niendo sus quejas (al virrey viceprotector de la Real Academia) relativas a que se les obligaba a trabajar "día y noche"; llámanse a sí mismos "Directores del buen gusto"; informan que no se cumple con el reglamento; dicen que nada se conseguiría respecto al orden "mientras no se separe al director don Gerónimo Gil", a quien denigran, acusándole de ser el causante de la locura de Arias y acusan también de parcial al secretario de la academia (sin fecha, 18 hojas) (rúbricas). Al margen: certificación y entrega. México, junio 7 de 1788.

282. Certificación de don Antonio Piñeiro del acuerdo para que las juntas se celebren los primeros jueves de cada mes, según el acuerdo respectivo. México, junio 23 de 1788 (rúbrica).

283. Representación de varios pensionados contra la actitud de los directores, quejándose de las deficiencias de su enseñanza y pidiendo se haga justicia. México, junio 19 de 1788. Ignacio Sandoval, José María Vázquez, Bernardo Gil, Juan Mariano Sandoval, Gabriel Gil, 'Tomás Suría, Luis de Martín Alonso, José Gutiérrez (rúbricas).

284. Oficio de don Angel de Cuevas Aguirre y Avendaño (al presidente de la Real Academia), informando sobre lo que a él le parece debe hacerse para el nombramiento anual de facultativos que en lo jurídico valúen las obras de pintura, escultura, arquitectura y grabado. Pide se proceda a la elección puesto que no existen los motivos que impulsaron a don Fernando Mangino y a la junta para suspender la práctica. Da la razón a los señores directores en este punto, en relación con su solicitud (véase el núm. 281). México, agosto 29 de 1788 (núbrica).

285. Oficio del virrey Flores a la Real Junta de la academia, remitiendo copia de la Real Orden de 12 de diciembre de 1788 y el recurso hecho a S. M. por los directores de pintura y arquitectura en que se quejan del tratamiento áspero que les daba don Jerónimo Antonio Gil, para que en vista de los documentos informe lo conveniente. México, marzo 28 de 1789. Flores y Antonio Bonilla (rúbrica).

286. Copia certificada de la instancia de los directores, sobre que se les releve de asistir de día a la academia y resolución de S. M. sobre el asunto. 1788. Legajo incluido en el número 280 conteniendo el documento número 287.

287. Copia certificada por don Antonio Piñeiro del expediente original que se pasó a manos de $\mathrm{S}$. E. (el virrey) con esta fecha. México, junio 19 de 1788 (rúbricas). Contiene: el pedimento de los directores para que no se les obligue a concurrir de día; decreto del 
virrey Flores para que el señor Posada disponga las cosas de la mejor manera. Informe del consiliario decano; copia de lo acordado en la junta ordinaria; orden a los directores por disposición del señor presidente para que concurran mañana, tarde y noche a la academia; informe del director Gil, sugiere que vuelvan a España los directores y se defiende de los cargos que se le hicieron; acuerdo de la junta superior de gobierno, dando en parte la razón a Gil. Certificación del secretario.

288. Oficio de la junta al virrey Flores remitiéndole la copia certificada del expediente, con el acuerdo de la misma (véase el documento número 287), para su resolución. Asunto de los directores sobre que se les releve de asistir de día a la academia (copia). Junio 19 de 1788 .

289. Oficio del virrey Flores a la Real Junta de la Academia, sobre el asunto de relevar a los directores de asistir de día a la academia. Incluye la exposición del señor fiscal de lo civil, totalmente de acuerdo con las resoluciones de la junta y pide se aperciba y reprenda a don Ginés Andrés de Aguirre y a don Cosme de Acuña por desobedecer las órdenes de la misma junta. México, julio 18 de 1788 (rúbrica).

290. Oficio del virrey conde de Revillagigedo a la junta general de gobierno de la Real Academia, transcribiendo la orden del rey comunicada por don Antonio Porlier, en que se ratifica el acuerdo de la junta cn el sentido de que los directores asistan por la mañana, tarde y noche (rúbrica). México, agosto 20 de 1790.

291. Oficio del presidente de la junta al virrey conde de Revillagigedo, informándole que ha quedado aquélla enterada de la Real Orden de 3 de marzo y que ya se comunicó a los directores de la academia (rúbrica). México, septicmbre 10 de 1790. Al margen: Acordado en 26 de agosto de 1790 .

292. Instancia de José María Zamarripa sobre que se le provea de los colores necesarios para empezar a pintar. 1788. Legajo contcnicndo el documento número 293.

293. Oficio de don José María Zamarripa (al presidente de la Real Academia) pidiendo se le provea de colores necesarios para pintar, alegando su extrema pobreza (ríbrica). Al margen acordado en junta de 31 de octubre de 1788.

294. Representación del señor presidente (de la academia) al señor viceprotector (virrey de Nueva España) participándole lo acordado por la junta superior de gobicrno sobre la remisión de 13 mil pesos a 
España para la compra de útiles: con la contestación de S. E. 1788. Legajo conteniendo los documentos números 295 y 296.

295. Oficio del presidente de la junta al virrey, dándole cuenta de que están listos para enviarse, en un buque de guerra, los 13 mil pesos para compra de libros, colores y demás útiles, según las listas formadas por los directores, y en cumplimiento de la Real Orden de 12 de abril de 1786 (copia). México, octubre 15 de 1788.

296. Oficio del virrey Flores al presidente de la Real Academia informándole que ya ha girado sus órdenes para que los ministros de la Real Hacienda en Veracruz registren como caudales de S. M. en la fragata de guerra "La Venus", los trece mil pesos para la compra dc útiles. México, octubre 17 de 1788. Flores y Fernando de Córdova (rúbricas).

297. Representación de S. E. (el virrey) sobre la necesidad de proceder a la elección de presidente y de que se aumente el número de consiliarios con la contestación que dio en cl asunto. 1788. Legajo conteniendo los documentos números 298 y 299.

298. Oficio de la junta superior de gobierno al virrey Flores, proponienclo se aumente el número de consiliarios y la elección de presidente, pues se encontraba vacuo el puesto por renuncia de don Fernando José Mangino (copia). Abril 30 de 1788.

299. Oficio del virrey Flores a la junta de la Real Academia, informando sobre que tiene escrúpulos para proponer las personas para presidente y consiliarios, por la influencia que pudiera tener en la junta su opinión y que ya consultó el caso con S. M. y espera la resolución. México, mayo 16 de 1788 (rúbrica).

300. Representación de la junta de gobierno al excelentísimo señor viccprotector proponiéndole para su presidente al señor consiliario decano don Ramón de Posada, con la contestación de S. E. y aprobación de S. M. 1788 y 89. Legajo conteniendo los documentos números $301,302,303$ y 304 .

301. Oficio de la junta de la Real Academia al virrey Flores, proponiendo tres personas de las cuales se escoja la que deba ocupar el puesto de presidente. Los propuestos son: don Ramón de Posada, don Josć Ángel de Cuevas Barroso (sic) y Torrubia (copia). México, julio 4 de 1788.

302. Oficio del virrey Flores a la Real Junta, informando que ha nombrado presidente de ella a don Ramón de Posada, en decreto de 7 de julio de 1788. México, julio 10 (rúbrica).

303. Oficio del virrey Flores a la Real Junta, trasmitiendo la Real aprobación del nombramiento de don Ramón de Posada para presi- 
dente. México, marzo 28 de 1789. Flores y Antonio Bonilla (rúbricas).

304. Oficio de la junta al virrey por el cual le avisa que queda enterada de la Real aprobación del nombramiento de don Ramón de Posada para presidente (copia). México, abril 18 de 1789.

305. Pedimento del director general don Gerónimo Antonio Gil acompañando copia simple de la representación que hicieron a S. M. los directores particulares don Ginés de Aguirre, don Cosme de Acuña y don Antonio González Velázquez; y quejándose de las expresiones que vierten en ella contra su conducta, con la representación que la junta superior hizo sobre el asunto al excelentísimo señor don Antonio Porlier. 1788. Legajo conteniendo los documentos números 306, 307 y 308 .

306. Oficio de don Gerónimo Antonio Gil (al virrey) exponiendo las circunstancias en que pasó a Nueva España, con Tomás Suría, José Esteva y sus dos hijos. Afirma que de él partió la idea de establecer la academia y que se la comunicó a don Fernando Mangino, quien puso varias dificultades; que trabajó solo hasta que le ayudaron gratuitamente los artistas residentes en México, y que al llegar los profesores de España no prestaron la debida atención a los estudiantes. Se queja amargamente de la representación que hicieron los directores, Aguirre, Acuña y González Velázquez y adjunta copia de la nisma para que examinado el caso "se mire por (su) honor grandemente ultrajado". México, septiembre 10 de 1788 (rúbrica). Al pie: Se puso la certificación con fecha 23 de octubre de 88 y se remitió al excelentísimo ministro de Gracia y Justicia, don Antonio Porlier en carta de 26 del mismo, conforme a lo acordado en junta el 11 de septiembre. Salió el duplicado en noviembre siguiente. Nota: la letra del oficio es claramente de la mano de Tomás de Suría. J. F.

307. Copia simple de la representación de los directores, Ginés Aguirre, Cosme Acuña y Antonio González Velázquez, a S. M. en que se quejan del maltrato de Gil y piden se les releve de concurrir de día a la academia (véase el documento número 28) (sin fecha). 1788.

308. Oficio de la junta a don Antonio Porlier advirtiéndole de la representación que suponen fue enviada por los directores (número 307) a S. M. Encomian la actitud de Gil y proporcionan algunos detalles de la conducta de los directores. Ramón de Posada, Antonio Barroso y Torrubia, Antonio Basoco, el marqués de Ciria y el marqués de San Miguel de Aguayo (rúbricas) (copia). México, octubre 26 de 1788. Al margen: Salió el duplicado el 26 de noviembre del mismo año. 
309. Expediente formado por la elección de conserje verificada en don Diego Mestre y Pardo. 1788. Legajo conteniendo los documentos números 310, 311, 312 y 313.

310. Oficio de don Ramón de Posada al virrey Flores, sobre que se nombre conserje con todas las obligaciones, fianza y formalidades. Hasta entonces había servido como tal Diego Mestre y Pardo. Junio 2 de 1788 (rúbrica).

311. Oficio del fiscal de lo civil al virrey Flores indicándole que puede proceder la junta de la Real Academia a la elección de conserje (rúbrica). México, julio 7 de 1788 . A la vuelta el acuerdo del virrey: Como lo dice el señor fiscal de lo civil. Julio 9/88. Rúbrica.

312. Oficio de don Ramón de Posada al virrey, proponiéndole tres personas para el puesto de conscrje: don José Trelles, don Diego Mestre y don Antonio García. México, julio 23 de 1788 (rúbrica).

313. Oficio del fiscal de lo civil al virrey Flores aceptando como buenos los nombres de las tres personas propuestas para ocupar el puesto de conserje (rúbrica). México, agosto 16 de 1788. Al pie el acuerdo del virrey: Procédase desde luego a la elección ... (rúbrica). Agosto $19 / 88$.

314. Instancia del director del grabado en lámina don José Joaquín Fabregat, sobre que se le supla la cantidad de 753 pesos para pagar los gastos de conducción. 1788. Legajo conteniendo los documentos números $315,316,317$ y 318 .

315. Carta de don Joaquín Fabregat al presidente de la junta para que se le proporcione la cantidad de 753 pesos que debe pagar por gastos originados en su viaje a México. México, mayo de 1788 (rúbrica). Pide que se le dé lo que tenga devengado de sueldos desde el día de su embarque, 11 de febrero.

316. Oficio del presidente de la junta al virrey, exponiendo que como el sueldo devengado por Fabregat desde su embarque no alcanza sino a 86 pesos, pone en sus manos el asunto para que resuelva, consiclerando justa la petición de Fabregat. Junio 2 de 1788 (copia).

317. Certificado de don Manuel Ruiz de Reyna, escribano de la fragata "Vicente Ferrer" alias "La Galga", de la que era capitán don José Alessandri, sobre el embarque en Cádiz de don Joaquín $\mathbf{F a}$ bregat el 11 de febrero de 1788 con su mujer, hijo, sobrino y un criado. Abril 12 de 1788. Castillo de San Juan de Ulúa (rúbrica).

318. Oficio de don Ramón de Posada al virrey, informándole que se vio en junta el asunto de Fabregat y que encontrándolo justo acordó pasase a sus manos para resolver lo conveniente. Junio 2 de 1788 (rúbrica). 
319. Expediente formado sobre la demencia del director de escultura, don José Arias, con la Real Orden librada sobre el asunto en 23 de febrero de 89. 1788. Legado conteniendo los documentos números 320 y 342 , inclusive.

320. Escrito de don Cosme de Acuña y Troncoso al marqués de Uluapa, exponiendo que teniendo en su casa a don José Arias, éste perdió el juicio y pide se nombre un escribano para hacer el inventario dc sus bienes (rúbrica). Al pie auto: se haga en todo como la partc pide. Rúbricas. El marqués de Uluapa. Ovando y Felipe Francisco H. Pasalle, escribano. A continuación el inventario de los objetos propiedad de Arias que se encontraban en casa de don Cosme Acuña. Certificado por Francisco Palacios, escribano de S. M. Febrero 18 de 1788.

321. Oficio del virrey Flores a don Antonio Porlier, exponiéndole el asunto de la demencia de Arias, a quien la junta declaró incapaz de continuar en su empleo, tras el certificado de los facultativos de encontrarlo maníaco incurable. Pide se envíe otro profesor que percibirá sólo $\$ 1,500$ anuales, pues $\$ 500$ le asignó la junta al dicho Arias mientras viva, y a la muerte de éste se le darán $\$ 2,000$. Pidc se le suspenda la pensión de 24 reales de vellón diarios que se les daba en Madrid a las hermanas de Arias por cuenta de éste. Agosto 25 de 1788 (copia). México.

322. Oficio del presidente de la junta de la Real Academia al virrey Flores, avisándole que en vista del certificado médico del cirujano don José Longinos Martínez y del de los profesores de medicina doctor José Francisco Villarreal y don José García Jove, declarando maníaco e incurable al profesor don José Arias, se acordó declararle también incapaz de continuar en su puesto, asignándole por piedad $\$ 500$ anuales mientras viva, y que se pida otro profesor con $\$ 1,500$ pesos anuales mientras exista Arias y a su muerte se le darán $\$ 2,000$. Pasa el asunto a manos del virrey para que resuelva. México, 31 de julio de 1788 (copia).

323. Copia simple de las disposiciones tomadas en relación con la demencia del director de escultura don José Arias; desde que la mujer de Acuña pidió se extrajese de su casa, habiéndolo pasado al Convento-Hospital de Religiosas Belemitas el 23 de marzo, hasta la muerte de aquél, el día 5 de diciembre. Noticia de cosas de su propiedad (sin fecha). 1788.

324. Lista de las disposiciones que se tomaron con relación a la demencia de don José Arias (sin fecha). 1788. 
325. Certificado del fallecimiento de don José Arias Centurión, director que fue en la Real Academia de San Carlos, del ramo de escultura, el 5 de diciembre. Se le enterró en la iglesia del convento en la tarde del mismo día. Fray Miguel de Jesús (rúbrica). Presidente del Convento Belemítico de San Francisco Xavier de México. Diciembre 11 de 1788 .

326. Oficio de don Ramón de Posada al virrey Flores, haciendo instancia de la falta que hacía otro profesor, una vez muerto Arias (rúbrica). Diciembre 19 de 1788. Al margen el acuerdo: "Como pide el Sr. Presidente..." Flores, Valenzuela y Antonio Bonilla (rúbrica). Diciembre 17 de 1788.

327. Sobre la liquidación de la cuenta del difunto director de escultura, Arias, mandada por la Real Orden de 10 de febrero de 91. Legajo conteniendo los documentos números 328, 329, 330 y 331.

328. Oficio de la junta de gobierno de la Real Academia al virrey conde de Revillagigedo. Dan aviso de que don Antonio Barroso, comisionado para vender los objetos propiedad de Arias, juntó en efectivo $\$ 767$, pero que es necesaria la liquidación de la cuenta de las hermanas de Arias para saber el saldo y remitirlo a ésas, sus herederas. Agosto 25 de 1790. Ramón de Posada, Antonio de Basoco, Antonio Barroso y Torrubia, el marqués de San Miguel de Aguayo, el marqués de Ciria, Bernardo de Bonavía, Miguel Constanso (rúbricas). Al margen dos notas diciendo que ya se pidió la liquidación.

329. Oficio del virrey a la junta de la Real Academia, diciendo que ha dado cuenta a la corte del asunto pendiente, con relación a la muerte de don José Arias (copia). Septiembre 9 de 1790 (rúbrica).

330. Nota de las cantidades que han percibido doña Paula y doña Francisca Arias, hermanas de don José Arias (copia). México, mayo de 1791.

331. Oficio de don Antonio Bonilla (al fiscal de la Real Hacienda), remitiéndole la nota de las cantidades entregadas del caudal de la Real Hacienda en España a doña Paula y doña Francisca Arias, e informándole de otros detalles (copia). Mayo 25 de 1791 (rúbrica).

332. Cuenta de lo que corresponde a la Real Hacienda por los suplementos hechos a las hermanas del difunto don José Arias. Formada con arreglo a la Real Orden de 10 de febrero. 1791.

333. Nota de lo que debe en Caxas Reales el director don José Arias por la asistencia dada en Madrid a sus dos hermanas. Junio 14 de 1781 .

334. Cuenta de lo que corresponde a la Real Hacienda por los suplementos a las hermanas del difunto don José Arias. 1791 (?) (sin fecha). 
335. Carta de don Femando de Córdova a don Ramón de Posada, diciéndole que disponga si Arias ha de pasar al Hospital de San Hipólito, por acuerdo del virrey (rúbrica). 1788.

336. Certificado de la demencia de don José Arias, por el médico facultativo que lo atendió don José Longinos Martínez. México, marzo 13 de 1788 .

337. Oficio del virrey Flores a don Antonio Porlier avisándole la muerte de don José Arias (copia). Enero 3 de 1789.

338. Cuenta de lo que hizo de gasto don José Arias para su curación, desde el 17 de febrero hasta el 23 de marzo de 1788. Marzo 27 de 1788. Cosme de Acuña y Troncoso (rúbrica). Dos notas al pie: una de Acuña y otra de Posada.

339. Certificado de la demencia de don José de Arias, por el médico don Francisco Villarreal. México, mayo 20 de 1788.

340. Oficio de don Ramón de Posada a don José García Jove, médico, pidiéndole su opinión sobre el estado de salud de Arias y si había esperanzas de alivio. Junio 25 de 1788 (rúbrica). A la vuelta empieza el certificado del doctor José García Jove, explicando que no tiene alivio. Junio 26 de 1788 (rúbrica).

341. Copia del acuerdo de la junta de la Real Academia concediendo $\$ 500$ anuales a don José de Arias mientras viva y que se pida otro director con $\$ 1,500$. Julio 30 de 1788. Antonio Piñeiro (rúbrica).

342. Oficio de don Ramón de Posada al virrey Flores, comunicándole lo acordado por la junta acerca de pedir un nuevo director con $\$ 1,500$ anuales, mientras viva Arias. Julio 31 de 1788 (rúbrica). Acuerdo: execútese desde luego lo que tiene acordado la junta (rúbrica), Flórez. Agosto 9 de 1788.

343. Copia del acuerdo de la junta superior de gobierno advirtiendo a los discípulos pensionados que se les multará por las horas de estudio que falten a la academia. Julio 9 de 1788 (sin firma).

344. Copia del oficio dirigido a don Francisco Antonio de la Peña y Flores, por la junta, avisándole que fue nombrado por el virrey el nuevo presidente de la misma, don Ramón de Posada. Julio 21 de 1788.

345. Copia del oficio dirigido a don Gerónimo Antonio Gil, director general de la academia, por la junta avisándole que ha sido nombrado presidente de la misma don Ramón de Posada. Julio 21 de 1788 (sin firma).

346. Copia de un oficio dirigido a don Gerónimo Gil (por el presidente de la junta) pidiéndole que informe sobre los pensionados y otros asuntos relativos. Julio 30 de 1788 (sin firma). 
347. Grabado en hueco. Don Juan José Gunemundo deł Castillo. Legajo conteniendo los documentos números 348 y 349.1788.

348. Oficio de don Juan José Gunemundo Castillo, solicitando se le tome en consideración para una pensión por las razones que expone (acompañaba el acta de bautismo que le fue devuelta) (rúbrica). 1788.

349. Certificado de don Cosme de Acuña y Troncoso sobre que las dibujos a que alude son originales y fueron ejecutados bajo su dirección por don Juan José Gunemundo del Castillo. Septiembre 16 de 1788.

350. Grabado en hueco. Don José María Zamarripa. Legajo conteniendo los documentos números 351, 352 y 353.

351. Oficio que dirige don José María Zamarripa al presidente de ia junta solicitando una de las pensiones para grabado en hueco (rúbrica). 1788 (sin fecha).

352. Certificado de don Ginés de Andrés y de Aguirre, sobre un dibujo de don José María Zamarripa. Septiembre 5 de 1788 (rúbrica).

353. Certificado de don Cosme de Acuña y Troncoso, sobre un dibujo ejecutado por don José María Zamarripa para la oposición de las pensiones de grabado en hueco. Septiembre 5 de 1788 (rúbrica).

354. Grabado en hueco. Don Francisco Lindo. Legajo conteniendo los documentos números 355 y 356. 1788.

355. Solicitud de don Francisco Lindo para una de las pensiones de grabado en hueco (rúbrica). 1788 (sin fecha).

356. Certificado de don Cosme de Acuña y Troncoso sobre la autenticidad de los dibujos presentados por don Francisco Lindo para las oposiciones de la pensión de grabado en hueco. Septiembre 15 de 1788 (rúbrica).

357. Copia del oficio de la junta dirigido al virrey flores en que se le da cuenta de haber acordado extender el edicto para la oposición de ocho vacantes ( $\sin$ firma). Julio de 1788.

358. Expendiente sobre la provisión de las pensiones vacantes, con copia del edicto que se fixó para el efecto. 1788.

359. Copia del edicto que se fijó en la capital para la oposición de ocho pensiones de la academia; dos para indios puros y seis para españoles. pobres. Tenían que presentar un memorial con sus méritos y su fe de bautismo. Julio 6 de 1788 (rúbrica).

359 bis. Ofcio del excelentísimo señor viceprotector al señor presidentedon Ramón de Posada avisándole quedar enterado de la elección de pensionados hecha por la junta con arreglo al estatuto. Legajo conteniendo los documentos números 360 y 361, 1788. 
360. Oficio de la junta al virrey Flores informándole del acuerdo tomado para extender el edicto, relativo a las ocho pensiones vacantes, del cual le adjuntan copia para que se fije en los sitios acostumbrados, en la capital (rúbrica). Junio 23 de 1788.

360 bis. Oficio de la junta al virrey Flores enterándole de haber elegido por votación a los pensionados. Salieron electos: escultura: don Pedro Antonio Patiño Estolinque, don Juan de la Cruz, don Manuel José López; arquitectura: don Luis Martínez, don Mariano Bustamante y don Manuel Muñoz, y en el grabado en hueco: don José María Montes de Oca y don Manuel López. Septiembre 25 de 1788 ( $\sin$ firma).

361. Oficio del virrey Flores al presidente de la Real Academia, dándose por enterado de la elección de pensionados. Septiembre 30 de 1788. Flores y Fernando de Córdova (rúbricas).

362. Escultura. Don Miguel Albear. 1788. Legajo conteniendo los documentos números 363 y 364.

363. Certificado de don Cosme de Acuña y Troncoso sobre los dibujos que presenta don Miguel Albear. Septiembre 16 de 1788 (rúbrica).

364. Solicitud de don Miguel Albear para una de las pensiones de escultura (rúbrica) (sin fecha). 1788.

365. Arquitectura. Don Luis de Martín. Legajo conteniendo los documentos números 366 y 367.1788.

366. Solicitud de don Luis de Martín para una de las pensiones del ramo de arquitectura. Septiembre 5 de 1788 (rúbrica).

367. Certificado de don Antonio Velázquez sobre la autenticidad de los planos presentados por don Luis de Martín en las oposiciones para pensionados. Septiembre 2 de 1788. (rúbrica).

368. Arquitectura. Don Mariano Bustamante. Legajo conteniendo los documentos números 369 y 370 .

369. Solicitud de don Mariano Bustamante para una de las pensiones del ramo de arquitectura (rúbrica) (sin fecha). 1788.

370. Certificado de don Antonio Velázquez sobre la autenticidad de los planos presentados por don Mariano Bustamante en las oposiciones para pensionados. Septiembre 12 de 1788 (rúbrica).

371. Arquitectura. Don Manuel Muñoz. Legajo conteniendo los documentos números 372, 373 y 374. 1788.

372. Solicitud de don Manuel Muñoz para una de las pensiones del ramo de arquitectura (rúbrica) (sin fecha). 1788.

373. Copia certificada de la fe de bautismo de don Manuel Muñoz. Septiembre 2 de 1788. Licenciado y maestro Juan Antonio Bruno. 
374. Certificado de don Antonio Velázquez sobre la autenticidad de los planos que presentó don Manuel Muñoz en las oposiciones para pensionados. Septiembre 2 de 1788 (rúbrica).

375. Grabado en hueco. Don José María Montes de Oca. Legajo conteniendo los documentos números 376 al 380 inclusive. 1788.

376. Certificado de don José de Alcíbar sobre la autenticidad de un dibujo presentado por don José María Montes de Oca. Septiembre 16 de 1788 (rúbrica).

377. Solicitud de don José María Montes de Oca para una pensión de grabado en hueco (rúbrica) (sin fecha). 1788.

378. Copia certificada de la fe de bautismo de don José María Montes de Oca. Juan Francisco Domínguez (rúbrica). Agosto 2 de 1788.

379. Certificado de don Cosme de Acuña y Troncoso sobre la autenticidad de unos dibujos presentados por don José María Montes de Oca en las oposiciones de pensionados. Septiembre 3 de 1788 (rúbrica).

380. Renuncia que hizo don José María Montes de Oca de la pensión que obtenía en el ramo de grabado en hueco. Año de 1796. Excelentísima junta superior de gobierno. José María Montes de Oca (rúbrica, sin fecha).

381. Grabado en hueco. Don Manuel López. Legajo conteniendo los documentos números 382 y 383. 1788.

382. Certificado de don Ginés de Andrés y de Aguirre sobre la autenticidad de los dibujos presentados por don Manuel López en las oposiciones para pensionados. Septiembre 2 de 1788.

383. Solicitud de don Manuel López para ser admitido en las oposiciones para pensionados. Septiembre de 1788 (rúbrica).

384. Escultura. Pedro Patiño Estolinque. Legajo conteniendo los documentos números 385, 386 y 387. 1788.

385. Solicitud de Pedro Patiño Iztolinque para una de las pensiones de escultura o de grabado en hueco (rúbrica sin fecha). 1788.

386. Certificado de don Santiago Cristóbal Sandoval sobre la autenticidad de los modelos presentados por don Pedro Patiño Estolinque en las oposiciones para pensionados. Septiembre 4 de 1788 (rúbrica).

387. Copia certificada de la fe de bautismo de don Pedro Patiño Estolinque. Bachiller Rafael Tiburcio Sandoval y Austria; Theodoro Antonio Barragán; Pascual Pérez (rúbricas). Septiembre 6 de 1788.

388. Escultura. Juan de la Cruz. Legajo conteniendo los documentos números 389, 390 y 391.1788. 
389. Solicitud de don Juan de la Cruz para una pensión en el ramo de escultura. Septiembre 2 de 1788 (rúbrica).

390. Copia certificada de la fe de bautismo de don Juan de la Cruz. Diego Alvarez (rúbrica). Agosto 6 de 1788.

391. Certificado de don Santiago Sandoval sobre la autenticidad de los modelos presentados por don Juan de la Cruz en las oposiciones para pensionados (rúbrica). Septiembre 2 de 1788.

392. Escultura. Manuel de la Cruz. Legajo conteniendo los documentos números 392, 393, 394 y 395. 1788.

393. Solicitud de don Miguel de la Cruz para una pensión del ramo de escultura (rúbrica sin fecha). 1788.

394. Copia certificada de la fe de bautismo de don Miguel de la Cruz. Agosto 6 de 1788. Diego Alvarez (rúbrica).

395. Certificado de don Santiago Sandoval sobre la autenticidad de los modelos presentados por don Miguel de la Cruz en las oposiciones para pensionados. Septiembre 4 de 1788 (rúbrica).

396. Escultura. Manuel Joseph López. Legajo conteniendo los documentos números 397 al 403 inclusive. 1788.

397. Renuncia que hizo don Manuel López de la pensión que obtenía en el ramo de grabado en hueco. Año de 1797.

398. Renuncia presentada por don Manuel José López, de la pensión que obtenía en el ramo de grabado en hueco (rúbrica sin fecha). 1797.

399. Copia simple del bando en que se anunció una pensión vacante en el ramo de pintura, con la asignación de cuatro reales diarios. Enero 16 de 1796.

400. Solicitud de don Manuel José López para una pensión en el ramo de escultura (rúbrica sin fecha). 1788.

401. Copia certificada de la fe de bautismo de don Manuel José López. Agosto 19 de 1788. Juan Francisco Domínguez (rúbrica).

402. Certificado de don Cosme de Acuña y Troncoso sobre la autenticidad de los modelos presentados por don Manuel José López en las oposiciones para pensionados. Septiembre 4 de 1788 (rúbrica).

403. Certificado de don José de Alcíbar sobre la autenticidad de un dibujo presentado por don Manuel José López en las oposiciones para pensionados. Septiembre 9 de 1788 (rúbrica).

404. Escultura. Ignacio de la Rosa. Legajo conteniendo el documento número 405.1788.

405. Solicitud de don Ignacio de la Rosa para una pensión en el ramo de escultura (rúbrica). 1788. 
406. Arquitectura. José María Fernández Corona. Legajo conteniendo eI documento número 407.

407. Certificado de don Antonio Velázquez sobre la autenticidad de los planos presentados por don José María Fernández de la Corona en las oposiciones para pensionados (rúbrica). Septiembre 2 de 1788.

408. Arquitectura. Mariano José de Aguirre. Legajo conteniendo los documentos números 409 y 410.1788.

409. Solicitud de don Mariano José de Aguirre para una de las pensiones en el ramo de arquitectura (rúbrica sin fecha). 1788.

410. Certificado de don Antonio González Velázquez sobre la autenticidad de los planos presentados por don Mariano José de Aguirre en las oposiciones para pensionados. Septiembre 5 de 1788 (rúbrica).

411. Informe del director don Gerónimo Antonio Gil a don Ramón de Posada, sobre la aplicación y mérito de los pensionados. Agosto 13 de 1788 (rúbrica).

412. Representación del teniente coronel de ingenieros don Miguel Constansó, sobre los abusos introducidos en la presentación de planos a la academia. Diciembre 24 de 1799 (rúbrica).

413. Oficio de la junta de policía acompañando los planos formados para la construcción de unas casas en el Puente de San Francisco con el informe del teniente coronel de ingenieros, don Miguel Constansó. 1788. Legajo conteniendo el documento número 414.

414. Oficio de la Real junta de policía a la Real Academia, acompañando planos formados por don Ignacio Castera para unas casas que va a construir en el Puente de San Francisco, en sitio perteneciente al Convento de Santa Brígida. Noviembre 20 de 1788. Bernardo Banavía, Joaquín Romero de Caamaño, Angel de Cuevas Aguirre y Avendaño, el marqués de Uluapa, Juan Antonio Gómez (rúbricas). Al margen comienza el informe de Constansó. Diciembre 15 de 1788 (rúbrica).

414 bis. Expediente sobre la aprobación de los planos formados para la construcción de casas y portales en la calle de los Tlapaleros, con el informe que hizo el director don Antonio González Velázquez. 1788. Legajo conteniendo los documentos números $415,416,417$ y 418 .

415. Oficio de la Real junta de policía a la academia sobre los planos formados por don José Damián Ortiz para unas casas y portales que va a construir en la calle de Tlapaleros. Mayo 29 de 1788. José de Ayala Matamoro, Joaquín Romero de Caamaño, el Marqués de Uluapa, Juan Antonio Gómez (rúbricas). 
416. Acuerdo de don Ramón de Posada para que informe sobre los planos a que se refiere el oficio anterior (ver número 415). Don Antonio González Velázquez (rúbrica). Mayo 31 de 1788.

417. Informe de don Antonio González Velázquez aprobando los planos presentados por don José Ortiz, pero en cuanto al del maestro don José Joaquín García de Torres para una capilla de Tercer Orden de Nuestra Señora del Carmen, pide que se muestren planos y alzados para poder dictaminar. Junio 7 de 1788 (rúbrica).

418. Oficio de don Ramón de Posada a la junta de policía devolviendo los planos de don José Damián Ortiz y el de don José Joaquín García Torres. Junio 21 de 1788.

419. Legajo conteniendo los documentos números 420 y 421 (toda la parte superior comida por las ratas). Tercer Orden de Nuestra Señora del Carmen. 1786 (véanse números 417 y 418).

420. Oficio de don Juan Francisco de Velasco presentando un plano para la construcción de la capilla del Tercer Orden de Nuestra Señora del Carmen. 1788 (rúbrica). Al margen acuerdo: que informe el director de arquitectura don Antonio González Velázquez (véase número 417). Octubre 10 de 1786 . $\mathrm{Al}$ pie: acuerdo pidiendo se presenten planos y alzados.

421. Acuerdo del presidente de la Real Junta de la Academia (Mangino) que se devuelva el expediente con el plano de la Noble Ciudad para que mande arreglarlo en los términos que expresa el director de arquitectura. Julio 13 de 1787 (rúbrica).

422. Orden a los directores don Ginés de Aguirre y don Cosme de Acuña para que alternen por las noches en la asistencia a las salas del natural y del yeso. 1788. Legajo conteniendo los documentos números 423 y 424.

423. Instancia a los profesores don Cosme de Acuña y don Ginés de Aguirre para que concurran por las noches a las salas del natural y del yeso. Al margen: "y corrigiendo y estando precisamente en ellas para quanto se ofreciere". Junio 5 de 1788.

424. Oficio de don Cosme de Acuña y Troncoso al secretario don Antonio Piñeiro, dándose por enterado del ofieio anterior (véase número 423). Junio 7 de 1788 (rúbrica).

425. Oficio del presidente de la Real Academia al virrey Flores, informándole del estado de cuenta y pasándole un libramiento para que lo firme. Junio 2 de 1788.

426. Contestación del excelentísimo señor viceprotector al oficio que le pasó la junta de gobierno participándole la elección de conserje en 
don Diego Mestre y Pardo. 1788. Legajo conteniendo los documentos números 427, 428, 429 y 430.

427. Oficio del presidente de la junta al virrey Flores recomendándole se nombre conserje, puesto que había desempeñado hasta entonces don Diego Mestre (copia). Junio 2 de 1788.

428. Oficio del presidente de la junta al virrey Flores recomendando tres sujetos para el puesto de conserje: don José Trelles, don Diego Mestre y Pardo y don Antonio García. Julio 23 de 1788 (copia).

429. Oficio del presidente de la junta al virrey Flores participándole haber salido electo don Diego Mestre y Pardo para el puesto de conserje. Septiembre 25 de 1788 (copia).

430. Oficio del virrey Flores al presidente de la Real Academia dándose por enterado del acuerdo de la junta sobre la elección de don Diego Mestre y Pardo para el puesto de conserje que venía desempeñando interinamente. Septiembre 30 de 1788. Flórez y Fernando de Córdova (rúbricas).

431. Oficio del presidente de la Real Academia al virtey Flores, informándole de las cuentas y pasándole un libramiento para que lo firme. Mayo 6 de 1788 (copia).

432. Oficio del virrey Flores a don Manuel González Guiral (Cádiz) informándole que en la fragata "La Esperanza", que saldrá de V. C. en noviembre van asegurados $\$ 3,150$ por cuenta del caudal de la Real Academia, por las cantidades que se suplieron "para transporte a este Reyno a los Directores de ella" octubre 26 de 1788 (duplicado).

433. Oficio del presidente de la Real Academia al virrey Flores, informándole sobre las cuentas y enviándole documentos para que los firme (copia). Mayo 6 de 1788.

434. Oficio del virrey Flores a don Antonio Porlier, informándole que en la fragata "La Esperanza" que saldrá de V. C. en noviembre se remiten asegurados $\$ 3,150$ del caudal de la Real Academia por las cantidades que se suplieron para el transporte a este reino de los señores directores don Ginés de Andrés y Aguirre, don Antonio González Velázquez y don José Joaquín Fabregat. Octubre 26 de 1788 (duplicado).

435. Oficio del virrey Flores a don Antonio Valdés, informándole que la academia ha comprado el sitio de Nilpantongo en $\$ 30,000$ para construir su edificio acompaña los planos para que elija. Enero 25 de 1788 (duplicado).

436. Oficio de la junta de gobierno de la Real Academia sobre los directores Aguirre, Acuña y Velázquez piden que se les releve de asistir 
de día a ella. Agosto 27 de 1788. Ramón de Posada, Antonio Barroso y Torrubia, Antonio de Basoco, el marqués de Ciria, el marqués de S. Miguel de Aguayo (rúbricas) (A. D. Antonio Porlier).

437. Superior orden para que se coloquen en la academia e incluyan en el inventario las pinturas cedidas por el señor don Fernando Mangino. 1788. Legajo conteniendo los documentos números 438, 439 y 440 .

438. Oficio del virrey Flores a don Ramón de Posada informándole que don Fernando Mangino ha cedido un tablero de Teniers, dos retratos de pintores y un lienzo grande que representa una alacena; que estas pinturas están en poder de don Gerónimo Antonio Gil y que deben colocarse en la academia e incluirse en el inventario. Abril 11 de 1788 (rúbrica).

439. Oficio de don Ramón de Posada al virrey Flores, informándole que ha cumplido con sus disposiciones relativas a las pinturas cedidas a la academia por don Fernando Mangino. Abril 23 de 1788 (copia sin rúbrica).

440. Oficio de don Ramón de Posada a don Fernando José Mangino dándole las gracias, en nombre de la academia, por las cuatro piezas de pintura y grabado que se sirvió obsequiar. Abril 23 de 1788 (copia sin rúbricas).

441. Oficio del virrey Flores al bailío don Antonio Valadés, informándole que en la fragata "La Esperanza" van asegurados los \$ 3,150 que de la caja de la Real Hacienda se dieron en esa corte (Madrid) a los directores que pasaron a Nueva España. Octubre 26 de 1788 (rúbrica, duplicado).

442. Expediente sobre la aprobación de los planos formados para construcción de dos casas en la esquina cerrada del Parque. 1788. Legajo conteniendo los documentos números 443, 444 y 445.

443. Oficio de la junta de policía a la Real Academia remitiendo un plano ignográfico de las casas situadas en "la Esquina zerrada de el Parque" (sic), pertenecientes al convento de San José de Gracia, presentado por el maestro de arquitectura don José Joaquín de Torres, para que se revisen y se devuelvan. Julio $1^{\circ}$ de 1788 . José Ayala Matamoros. Joaquín Romero de Caamaño, Angel de Cuevas Aguirre y Avendaño, Juan Antonio Gómez (rúbricas).

444. Informe de don Antonio González Velázquez sobre los planos presentados por don José Joaquín de Torres para la construcción de las casas en la Cerrada del Parque; pide presente elevación de fachada para dictaminar sobre ella pues "que debe la Academia celar sea con algún arreglo, pues puede tenerle sin aumentar gastos sólo con 
la buena ordenación de huecos en puertas y ventanas..." Septiembre $1^{\circ}$ de 1788 (rúbrica).

445. Copia del acuerdo de la junta de la Academia, remitido a la Real junta de policía de esta Noble Ciudad con copia del informe del director de arquitectura, don Antonio González Velázquez. Febrero 21 de 1789.

445 a. Cuenta de los gastos erogados en el año próximo pasado de 1788. Legajo con 36 páginas. Cuentas rubricadas por don Diego Mestre y don Gerónimo Antonio Gil.

Gaveta 4. $1789-1790$ (números del 446 al 620).

446. "Explicación de la alegoría tomada para la solemne proclamación de nuestro augusto Monarca el Sor. Dn. Carlos IV en los tres tablados eregidos para este acto que se ha de celebrar el 27 de diciembre de 1789". El primer tablero en la Plaza Mayor; el segundo enfrente del Palacio Arzobispal y el tercero frente a la Diputación.

447. Oficios pasados al Ilustre Ayuntamiento de esta Noble Ciudad sobre la satisfacción de los $\$ 2,000$ que debe de la pensión respectiva a los años de 87 a 88: su contestación y la representación que se hizo a S. E. sobre el asunto. Dos órdenes de S. E. y la representación que se dirigió al excelentísimo señor Porlier participando esta renta del Cabildo. 1789. Expediente conteniendo los documentos números 448 al 455 , inclusive.

448. Oficio de la junta de la Real Academia al Ayuntamiento de esta Noble Ciudad. Participando el nombramiento de don Antonio Piñeiro para cobrar las rentas. Diciembre 3 de 1788 (copia).

449. Oficio del Cabildo a la junta de la Real Academia, dice queda enterado del poder conferido a don Antonio Piñeiro para cobrar las rentas y que ya se pasa el asunto a la junta municipal de propios para que se tome la providencia oportuna. Diciembre 11 de 1788 . 'Tomás de Urizar, Antonio Méndez Prieto, Antonio Rodríguez de Velasco, Ildefonso José Prieto de Bonilla, Luis González Gómez Maldonado, Juan Antonio Gómez (rúbricas).

450. Oficio de don Ramón de Posada al Ilustre Ayuntamiento de esta Noble Ciudad instándolo a que cubra las cantidades que adeuda a la academia por concepto del patrimonio asignado para su subsistencia. Marzo 23 de 1789 (rúbrica, duplicado).

451. Oficio de don Ramón de Posada al virrey Flores quejándose de que el Ayuntamiento no ha cubierto las cantidades que adeuda a la Aca- 
demia por la pensión que se le asignó a ésta para cooperar a su subsistencia. Junio 9 de 1789.

452. Oficio del virrey Flores a don Ramón de Posada informándole que ya pasó la orden correspondiente para que el Ayuntamiento de Noble Ciudad disponga se entreguen a don Antonio Piñeiro los $\$ 3,000$ que adeuda a la academia, a razón de $\$ 1,000$ anuales de subsidio. Junio 23 de 1789. Flórez, Antonio Bonilla (rúbricas).

453. Oficio del virrey Flores a don Ramón de Posada transcribiéndole el oficio dirigido por él al Ayuntamiento en que lo insta a pagar a la academia la pensión adecuada. Agosto 17 de 1789. Flórez, Antonio Bonilla (rúbricas).

454. Oficio de don Ramón de Posada al virrey informándole que antes de recibir el oficio anterior (455) ya estaba enterada y puesta en la caja de tres llaves la cantidad que el Ayuntamiento adeudaba a la academia. Septiembre 15 de 1789 (copia).

455. Oficio del virrey Flórez a don Antonio Porlier informándole de la reclamación de la academia por no haberle dado su pensión en tres años el Ayuntamiento; le remite copia del expediente y le pide tomar una resolución para "que la Academia no sufra iguales embarazos en lo sucesivo". Julio 26 de 1789 (copia).

456. Oficio del Real Tribunal de Minería acompañando el libramiento de los $\$ 5,000$ correspondientes a la pensión de este año. 1789. Legajo conteniendo los documentos números 457 y 458.

457. Libramiento del Tribunal de la Minería para que se paguen a la academia $\$ 5,000$ correspondientes a la pensión de este año. Mayo 14 de 1789 (copia). Fausto de Elhuyar, Ramón Luis de Liceaga, Antonio Barroso y Torrubia (rúbricas).

458. Oficio del Real Tribunal de la Minería a la junta de la Real Academia, incluyéndole el libramiento por $\$ 5,000$ para cubrir la pensión de este año. Mayo 14 de 1789. Fausto de Elhuyar, Ramón Luis de Liceaga, Antonio Barroso y Torrubia (rúbricas).

459. Oficio de la junta al director de matemáticas don Diego Guadalajara Tello avisándole que el día 2 de enero (de 1790) se abrirá el aula de matemáticas. Diciembre 5 de 1789 (copia).

460. Oficio del secretario de la junta al señor consiliario don José de Cuevas y Aguirre pidiéndole asista en su calidad de clavero a la introducción de los fondos de la academia en el arca de tres llaves. Enero 16 de 1789 (copia).

461. Oficio de don Ángel de Cuevas y Avendaño al secretario don Antonio Piñeiro informándole que se encuentra en una hacienda curándose el reumatismo, por lo tanto o lo aguarden o tomen las 
providencias necesarias para la introducción de los caudales de la academia en el arca de tres llaves. Hacienda de Aclapango (Tezcoco). Enero 28 de 1789 (rúbrica).

462. Oficio del secretario de la junta a don Angel de Cuevas y Aguirre dándole parte de que se le nombró para hacerse cargo de una de las tres llaves de el arca de caudales de la academia. Noviembre 7 de 1788 (copia).

463. Solicitud del conserje don Diego Mestre sobre que se manden componer los taburetes de la academia. 1789 (contiene el documento número 464).

464. Solicitud del conserje don Diego Mestre al presidente de la Real Junta para que se manden componer los taburetes de la academia. Diciembre 24 de 1789 (rúbrica).

465. Representación del señor presidente a S. E. sobre la necesidad de nombrar otro señor consilario que se haga cargo de la segunda llave de la caja de caudales ínterin se restituye a esta capital cl señor consiliario don Angel de Aguirre. 1789. Legajo conteniendo los documentos números 466 y 467 (véanse también los números 460,461 y 462).

466. Oficio de don Ramón de Posada al virrey Flores pidiéndole nombre otro consiliario para hacerse cargo de la segunda llave del arca de caudales de la academia, por la enfermedad y ausencia del señor Ángel de Cuevas y Aguirre. Enero 26 de 1789 (copia).

467. Oficio del virrey Flores a don Ramón de Posada dándole cuenta de haber nombrado a don Antonio Basoco en sustitución de don Ángel de Cuevas, para hacerse cargo de la segunda llave del arca de caudales. Febrero 4 de 1789. Flórez, Antonio Bonilla (rúbricas).

468. Instancias del director del grabado en lámina, don José Joaquín Fabregat, sobre que se le dé la habitación necesaria para enseñar a los discípulos del ramo de estampado y se le considere alguna gratificación por este trabajo con el informe del director don Gerónimo Antonio Gil y asignación que se le hizo de $\$ 300$ anuales. Incluye la aprobación de S. M. en virtud de que se le pago a Fabregat. 1789. Legajo conteniendo los documentos números 469 a 478 inclusive.

469. Oficio de don José Joaquín Fabregat al presidente de la junta pidiendo se le auxilie en los gastos para enseñar el estampado a sus discípulos (actividad fuera de su obligación). Marzo 19 de 1789 (rúbrica).

470. Informe de don Gerónimo Antonio Gil. Opina sobre la necesidad de tener buenos estampadores, como los que de Madrid se man- 
daron a aprender tal oficio a París, Ricarte y Espinosa, por ser éste un arte en sí. Cree conveniente que se destine a uno o dos para aprender el estampado y en cuanto a la gratificación que Fabregat pide por esto, la deja para que le den lo que crean más justo. Marzo 22 de 1789 (rúbrica). Al margen se resolvió en junta de 30 de abril de 89.

471. Oficio de don José Joaquín Fabregat al presidente de la junta, proponiéndole crear la enseñanza del estampado para la cual él mismo podía ser maestro en vez de llamar otro nuevo, de España. Noviembre 24 de 1789 (rúbrica).

472. Carta de don José Joaquín Fabregat a don Antonio Piñeiro enviándole unas pruebas de grabados estampados por los alumnos. Se informa de la necesidad de crear la enseñanza del estampado en la academia y se propone a sí mismo para ello. Febrero 27 de 1790 (rúbrica). Al margen: resuelto en junta de 27 de febrero de 90 .

473. Oficio de don José Joaquín Fabregat a don Antonio Piñeiro, en que expone sus razones acerca del arte del estampado, dice que ya ha empezado a enseñar a sus discípulos Marchena y Aguila y que en cuanto a la gratificación por este trabajo extra lo deja a la consideración de la junta de la Real Academia. Informa sobre el método de enseñanza que empleará. Junio 25 de 1790 (rúbrica).

474. Acuerdo de la Real junta pidiendo a Fabregat el cuanto de la gratificación, el tiempo que tomaría para instruir a los jóvenes y el método de enseñanza. Junio 21 de 1790 (copia) (véase el número 473).

475. Oficio de la junta al virrey Revillagigedo informándole que como resultado de las instancias que ha hecho don José Joaquín Fabregat para que se le asigne una gratificación por enseñar el arte del estampado, se acordó darle $\$ 300$ anuales, lo que le comunica para que si fuere de su aprobación lo ponga en conocimiento de S. M. o determinar lo que juzgue conveniente. Agosto 25 de 1790 (copia) (se le remitió copia del expediente).

476. Oficio del virrey Revillagigedo a la junta transcribiendo una carta de don Antonio Porlier en que participa que S. M. aprobó el acuerdo de la junta en el sentido de "por ahora", para que se le den a don José Joaquín Fabregat $\$ 300$ de gratificación anual por enseñar el arte del estampado, así como que se le cubran los gastos mensuales del material necesario. Mayo 19 de 1791 (rúbrica).

477. Oficio de don José Joaquín Fabregat al secretario de la junta diciéndole que puesto que $S$. M. ha aprobado su gratificación que lo 
comunique a la junta para que en tal virtud tome resolución. Agosto 27 de 1791 (rúbrica).

478. Oficio de don José Joaquín Fabregat al presidente de la Real Academia, quejándose de que le habían suspendido su gratificación de $\$ 300$ anuales por la enseñanza del estampado sin consentimiento de S. M. Pide que se le reponga. Febrero 22 de 1795 (rúbrica) (ver legajo entero número 468 ).

479. Representación del director general don Gerónimo Antonio Gil sobre que se gratifique a los sujetos que sirvieron a la academia antes de su formal erección. 1789. Legajo conteniendo el documento número 480.

480. Oficio de don Gerónimo Antonio Gil al presidente de la Real Academia, pidiendo se gratifique a los artistas que ayudaron a "corregir y dirigir" la academia desde su establecimiento hasta la fecha. Nota la diferencia entre criollo y "gachupín". La lista de artistas y otras personas mencionadas es la siguiente: Francisco Caplera. José Alcíbar. Santiago Sandoval. Rafael Gutiérrez. Andrés López. Mariano Vázquez. Juan Sáenz. Manuel de la Sema. Manuel García. Luis Gómez. Francisco Luelmo. Antonio Cervantes. Pedro Verdugo. Ildefonso Jiménez Caro. Manuel Gómez de Paz. Diego Mestre. 1789 (rúbrica, sin fecha).

481. Instancia de don José María Vallejo sobre que se le dé alguna gratificación por el tiempo que ha servido su padre don Francisco Vallejo. 1789. Legajo conteniendo los documentos 482 y 483.

482. Oficio de don Gerónimo Antonio Gil al presidente de la Real Academia, informándole sobre los servicios de Francisco Vallejo; dice que sólo trabajó 6 meses pues por enfermedad que le duró hasta la muerte no pudo atender más a la academia; que no regaló los cuadros de Nuestra Señora de Guadalupe y de San Gerónimo sino que los vendió en $\$ 100$, que por lo tanto se gratifique a su familia con unos $\$ 30$. Febrero 7 de 1789 (rúbrica) (véase el número 483).

483. Oficio de José María Vallejo a la Real Academia pidiendo una gratificación por los servicios de su padre: un año de servicios en la academia y la donación de unos lienzos (rúbrica). Al margen el acuerdo para que informe Gil, y otro en que se libraron $\$ 30$ en junta de febrero 9 de 1789.

484. Instancia de don Antonio García sobre que se le dé alguna gratificación por el tiempo que ha servido: asignación de $\$ 300$ y aprobación de S. E. 1789. Legajo conteniendo los documentos números 485 al 488 , inclusive. 
485. Oficio de don Antonio García a la Real Academia haciendo valer sus servicios en la misma como escribiente, desde los primeros documentos de su fundación. Pide $\$ 200$ anuales por el tiempo que ha servido. 1789 (rúbrica, véase el número 486).

486. Oficio de don Antonio Piñeiro al presidente de la Real Academia informando sobre los servicios del escribiente Antonio García. Diciembre 23 de 1789 (rúbrica).

487. Oficio (copia) de la junta al virrey informándole sobre la solicitud de Antonio García, diciendo que Piñeiro propuso se le den $\$ 300$ por una vez. Encro 9 de 1789.

488. Aprobación del virrey Flores del acuerdo para que se le diesen $\$ 300$ a don Antonio García. Enero 26 de 1789. Flórez. Antonio Bonilia (rúbricas).

489. Instancia del académico profesor supernumerario don Esteban González sobre que se le permita dirigir fábricas, como se executa con los de su clase en la de San Fernando de Madrid. 1789. Legajo conteniendo los documentos números 490 y 491.

490. Oficio de don Esteban González, académico profesor supernumerario de esta Real Academia, solicitando permiso para ejercer, fundamentando sus derechos para ello. 1789 (rúbrica, sin fecha). Acuerdo de Posada para que informe Gil (véase el número 491).

491. Oficio de don Gerónimo Antonio Gil al presidente de la Real Academia, informándole sobre la solicitud de don Esteban González en sentido afirmativo y elogioso, menciona el antecedente de don Francisco Caplera, académico supernumerario en 6 de marzo de 1768 , y recomienda se apruebe la solicitud especialmente por tratarse del "único y primer hijo de este Real Establecimiento". Marzo 22 de 1789 (rúbrica). Al margen: en junta de 4 de abril se vio y negó esta solicitud.

492. Representación a S. E. devolviéndole la instancia del director don Cosme de Acuña, sobre que se le permita pasar a España por tiempo de un año con copia certificada de lo acordado en junta superior de gobiemo. 1789. Legajo conteniendo los documentos números 493 y 494.

493. Copia del expediente relativo a don Cosme Acuña. $1^{\circ}$ Que pidieron se les releve de asistir de día a la academia los directores Acuña, Aguirre y Velázquez. $2^{\circ}$ Solución que se le dio al asunto. $3^{\circ}$ Primera instancia de Acuña sobre permiso para pasar a España. 4\% Segunda instancia de Acuña. $5^{\circ}$ No se accedió a la solicitud. 1789. 
494. Oficio de la junta al virrey Flores informándole sobre la solicitud de don Cosme Acuña para pasar por un año a España. Se le pasó copia de todo para que resolviese. Marzo 3 de 1789 (copia).

495. Solicitud del director de pintura don Cosme de Acuña sobre que se le permita pasar a España por un año con descuento de todo su sueldo. 1789. Legajo conteniendo el documento número 496.

496. Oficio de don Cosme de Acuña y Troncoso al presidente de la Real Academia, solicitando nuevamente se le conceda permiso para pasar a España, enumerando una serie de desgracias familiares que lo obligan a insistir en su solicitud aunque sea sin sueldo. Octubre 28 de 1789 (rúbrica).

497. Solicitud de Felipe Fabris (o Fabre) sobre que se le pague el trabajo que emprendió en el busto del excelentísimo señor don Matías de Gálvez. 1789. Legajo conteniendo los documentos números 498 y 499.

498. Oficio de Felipe Fabre, pintor de miniaturas, exponiendo que por orden de don José Fernando Mangino y de don Gerónimo Gil hizo en barro los bustos de los difuntos don Matías Gálvez y de Carlos 111 y que no ha recibido nada por este trabajo y pide se le recompense. 1789. Philipe Fabrcs, pintor (rúbrica).

499. Informe de don Gerónimo Antonio Gil sobre los bustos ejecutados por Felipe Fabris; dice que efectivamente los hizo y que se encuentran inventariados, siendo de justicia se le recompense. Septiembre 24 de 1789 (rúbrica).

500. Instancia de don Francisco Caplera sobre que en las juntas se le dé asiento preferente al que tiene don José de Alcíbar, con lo que éste expuso en el asunto; y una superior orden aprobando la resolución tomada por la junta de gobierno. 1789. Legajo conteniendo los documentos números 501, 502 y 503 .

501. Oficio de don Francisco Clapera pidiendo se le dé el lugar que le corresponde por antigüiedad, en las juntas (rúbrica). Al margen el acuerdo de Posada, diciendo que se pase la instancia a don José de Alcíbar para que exponga lo que quisiese. Septiembre 6 de 1788.

502. Oficio de don José de Alcíbar exponiendo las razones por las cuales debía ser el primero en calidad (rúbrica). Al pie el acuerdo diciendo que "se resolvió en la junta del 24 de abril, dando preferencia al Teniente Dn. José de Alcíbar” (rúbrica) 1789.

503. Oficio del virrey Revillagigedo al presidente de la Real Academia diciendo que ha encontrado infundada la solicitud de don Francisco Caplera para ocupar el lugar de teniente director de pintura, en la guía de forastcros; lo que comunica al señor presidente para que 
no se ignore el orden en la impresión de la referida guía. Diciembre 3 de 1790 (rúbrica).

504. Expediente sobre la aprobación de los planos formados para la construcción de casas y portales en la calle de los Tlapaleros, con el informe que hizo el teniente coronel de ingenieros don Miguel Constansó. 1789. Legajo conteniendo los documentos números 505 y 506.

505. Oficio de la Real junta de policía remitiendo los planos formados por don Ignacio Castera de las casas y portales mandados construir en la calle de Tlapaleros pertenecientes al Sagrado Convento de San Agustín. Bernardo Bonavía, don Angel de Cuevas Aguirre y Avendaño (y otras rúbricas). Diciembre 20 de 1788. Al margen el acuerdo de Posada para que informe Constansó. Al margen el informe de Constansó diciendo que por lo adelantado de la fábrica ya no se puede corregir y que por lo tanto es mejor conceder la aprobación. Enero 11 de 1789.

506. Oficio a la Real junta de policía devolviéndole el plano y adjuntándole el informe de Constansó y los demás documentos (copia). Febrero 21 de 1789.

507. Expediente formado sobre aprobación de los planos que levantó el maestro mayor de esta N. C. don Ignacio Castera para la fábrica en el Convento y Colegio de Religiosas de la Enseñanza. 1789. Legajo conteniendo los documentos números 508 a 512, inclusive.

508. Oficio de la Real junta de policía remitiendo para su estudio los pianos formados por don Ignacio Castera para la nueva construcción de las casas y Convento de la Enseñanza. Marzo 30 de 1789. Bernardo Bonavía (rúbrica). Al margen el acuerdo de Posada para que se pasen los planos y que informe don Antonio González Velázquez.

509. Oficio de don Ignacio Castera presentando los seis planos del Convento, colegio y casas particulares de la Enseñanza. Hace la descripción detallada del programa. Marzo 26 de 1789 (rúbrica).

510. Acuerdo de la Real junta de policía para que pasen los planos y la instrucción de Castera (número 509) a la Real Academia para su inspección. 1789. Gerónimo José 'Troncoso. Escribano Real (rúbrica).

511. Informe de don Antonio González Velázquez criticando en diversos puntos los planos presentados por don Ignacio Castera para la fábrica de Convento y casas de la Enseñanza. Julio 19 de 1789 (rúbrica). 
512. Oficio de don Ramón de Posada a la junta de policía devolviéndole los pianos de Castera para la Enseñanza, con copia certificada del informe de don Antonio González Velázquez. Julio 2 de 1789 (rúbrica, duplicado).

513. Expediente sobre la aprobación de los planos formados por el maestro don Ignacio Castera para Ia fábrica de una casa en el Puente de San Francisco. 1789. Legajo conteniendo los documentos núme$\operatorname{ros} 514,515$ y 516 .

514. Oficio de don Bernardo Bonavía, de la Real junta de policía, enviando nuevamente los planos de la obra de unas casas en el Puente de San Francisco que están a cargo de don Ignacio Castera. Febrero 20 de 1789 (rúbrica).

515. Informe reservado de don Miguel Constansó a los señores consiliarios de la Real Academia, diciendo que para que no se altere don Ignacio Castera con las modificaciones que se le deben hacer, que lo inviten a la academia, junto con su dibujante Francisco Reyes, para enseñarles el modo de trazar una escalera. Marzo 31 de 1789 (rúbrica).

516. Oficio de don Ramón de Posada a la Real junta de policía explicando los defectos, especialmente la escalera, de los planos presentados por Castera para las casas del Puente de San Francisco, y devolviendo los mismos con las observaciones hechas. Julio 6 de 1789 (rúbrica).

517. Oficio del virrey Flores a la Real junta de la Academia transcribiendo una carta de don Antonio Porlier en que dice que S. M. ha aprobado las decisiones de la junta en relación con la demencia de don José Arias. Mayo 16 de 1789. Flórez y Antonio Bonilla (rúbricas).

518. Copia del oficio anterior (número 517) relativo a la demencia de don José Arias. Agosto 15 de 1789. Piñeiro (rúbrica).

519. Arias. 1789. Legajo conteniendo los legajos números 520, 521 y 522.

520. Cuenta de las cantidades que percibió el secretario don Antonio Piñeiro, respectivas a los sueldos del director de escultura don José Arias y de las que se erogaron en sus asistencias, curación y entierro. 1789. Legajo con 19 hojas. El estado de cuentas firmado por Piñeiro y un oficio de certificación firmado por don Antonio Barroso y Torrubia.

521. Liquidación de las cantidades que del caudal de la Real Hacienda se supiieron en Madrid al director de escu'tura don José Arias para su transporte a este reino y alimentos de sus hermanas; y de lo que resulta debiendo por razón de este suplemento. 1789. Legajo con- 
teniendo el estado de cuentas firmado por Piñeiro y la certificación de don Antonio Barroso y Torrubia.

522. Inventario de los bienes de don José Arias; documentos sobre su avalúo y venta. 1789. Lcgajo conteniendo 21 hojas con el inventario, avalúos, oficio del virrey aprobando la venta, oficio de comisión a don Antonio Barroso para vender los bienes, cuenta de la venta e informe al virrey.

523. Cuenta de las cantidades que se suplieron en España a cada uno de los cinco directores particuiares de esta Real Academia de San Carlos, de los descuentos que se les han hecho hasta la fecha y de lo que resultan debiendo (se refiere a don Ginés de Andrés Aguirre, don Cosme de Acuña, don José de Arias, don Antonio González Velázquez y don Joaquín Fabregat). Abril 30 de 1788. Antonio Piñeiro (rúbrica).

524. Oficio del virrey Flores a la Real Junta de la Academia transcribiendo una carta de don Antonio Porlier en la que dice remite un ejemplar del Diccionario Manual de Pintura, Escultura, Arquitectura y Grabado, escrito por don Francisco Martínez, para uso de la academia. Mayo 16 de 1789. Flórez y Antonio Bonilla (rúbricas).

525. Oficio del virrey Flores a la Real Junta de la Academia transcribiendo una carta de don Antonio Porlier en que S. M. ordena se presenten tres candidatos a consiliarios para cubrir las vacantes en la junta. Mayo 9 de 1789. Flórez y Antonio Bonilla (rúbrica).

526. Acuse de recibo del oficio anterior (número 525). Mayo 26 de 1789 (copia).

527. Oficio de la Real Junta de la Academia al virrey, conde de Revillagigedo, informándole de las juntas mensuales y de los asuntos que se tratan en ellas y pide disponga lo que fuere de su agrado para las próximas. Noviembre 2 de 1789 (copia).

528. Oficio de la Real Junta de la Academia al virrey Flores, acerca de los incidentes ocurridos por obligar a los directores a concurrir de día a la academia; la junta respalda la actitud de don Gerónimo Antonio Gil. Piden que se resuelva el asunto. Abril 25 de 1789 (copia).

529. Oficio de la Real junta al virrey Flores, acerca de la instancia de los directores para que se les releve de asistir de día y dicen haber acordado que todo pase a don Gerónimo Antonio Gil para su informe. Abril 23 de 1788 (copia).

530. Minuta acusando el recibo del Diccionario Manual de Pintura, Escultura, Arquitectura y Grabado, dirigido por S. E. ron oficio de 16 de mayo, para uso de la academia. Mayo 26 de 1789 (copia). 
531. Renuncia que hizo de su pensión en el ramo de pintura, Agustín Cerezo. Al pie: Se admitió en junta de 9 de febrero de 89 y se nombró al supernumerario Luis Martínez (?).

532. Representación del director de matemáticas don Diego Guadalajara sobre las horas en que ha de dar sus lecciones a los pensionados y demás discípulos con el edicto o noticia que se le dio al público. 1789. Legajo conteniendo los documentos números 533 y 543.

533. Edicto (copia) de la junta superior de gobierno de la Real Academia avisando que el próximo mes de enero se abrirá el aula de matemáticas a la dirección de don Diego Guadalajara Tello. Diciembre 10 de 1789.

534. Representación de don Diego Guadalajara sobre las horas en que ha de dar sus lecciones y la necesidad de que se le aumente el sueldo. Al margen: acordado en junta de 18 de septiembre de 1789.

535. Expediente formado sobre la asistencia del teniente de pintura don Francisco Caplera de la academia, en los sábados por la noche. 1789. Legajo conteniendo los documentos números 536 y 537.

536. Oficio de don Francisco Caplera sobre su asistencia a la academia (al principio el aeuerdo de Posada para que informe Gil). marzo 3 de 1789 (rúbrica).

537. Informe de don Gerónimo Antonio Gil sobre la asistencia de Caplera apoyando su representación. Marzo 12 de 1789 (rúbrica) (acordada en junta de 4 de abril concediendo la gracia que se solicita).

538. Expediente formado a instancia del conserje don Diego Mestre y Pardo sobre que se le conceda licencia de curarse y se nombre sujeto que lo sustituya durante su enfermedad. 1789. Legajo conteniendo los documentos números 539, 540 y 541 .

539. Oficio de don Diego Mestre y Pardo declarando que por enfermedad no puede asistir a la academia y pide permiso para ausentarse mientras se restablece. Junio 12 de 1789 (rúbrica).

540. Certificación del licenciado Manuel Moreno sobre la enfermedad de don Diego Mestre (rúbrica). Junio 10 de 1789.

541. Oficio de don Diego Mestre diciendo que de acuerdo con lo clispuesto por la junta y mientras se encuentra enfermo, dejará en su lugar a su hijo Manuel (rúbrica). Junio 13 de 1789.

542. Dos certificaciones dadas por don Manuel Moreno y por don José Anastasio Pardo, profesores de cirugia, que acreditan la indisposición que padece el conserje don Diego Mestre. 1791. Legajo conteniendo los documentos números 543 y 544. 
543. Certificado del licenciado Manuel Moreno relativo a la enfermedad de don Diego Mestre. Al margen un acuerdo de Posada (rúbrica). Enero $1^{\circ}$ de 1791.

544. Certificado de don José Anastasio Pardo relativo a la enfermedad de don Diego Mestre (rúbrica). Marzo 8 de 1791.

545. Expediente sobre nombramientos de consi iarios hechos el año de 1789 en los S. S. Don Fausti de Elhuyar, don Miguel de Constansó y don Bernardo de Bonavía. 1789-1790. Legajo conteniendo los documentos númetos 546 a 556 , inclusive.

546. Oficio de la junta al virrey informándole que quedó vacante el empleo de consiliario que tenía don Ramón de Posada, por causa de su ascenso, y proponiendo a: ${ }^{\circ}$ Don Francisco Fcrnández de Córdova; $2^{\circ}$ Don Miguel Constansó, y $3^{\circ} \mathrm{El}$ conde de Santiago. Mayo 26 de 1789 (copia).

547. Oficio de la junta al virrey, informándole haber quedado vacante el empleo de consi'iario que tenía don Joaquín Velázquez de León. por fallecimiento, y proponiendo para ocuparlo a: $1^{\circ}$ Don Fausto de Elhuyar; $2^{\circ}$ Don Ramón Luis de Liceaga, y $3^{\circ} \mathrm{El}$ marqués del Apartado. Mayo 26 de 1789 (copia).

548. Oficio de la junta al virrey informándole haber quedado vacante el empleo de consiliario que tenía don Francisco Crespo, por fallecimiento de éste y proponiendo a: $1^{\circ}$ Bernardo Bonavía; $2^{\circ} \mathrm{El}$ marqués de Uluapa, y $3^{\circ}$ Don Joaquín Romero Caamaño. Mayo 26 de 1789 (copia).

549. Oficio del virrey Flores a la junta informándole haber hecho nombramiento para consiliario en favor de don Bernardo Bonavía. Flórez (rúbrica). Junio 5 de 1789.

550. Oficio del virrey Flores a la junta informándole haber hecho nombramiento para consiliario en favor de don Fausto de Elhuyar. Florez (rúbrica). Junio 5 de 1789.

552. Oficio del virrey Flores al presidente de la Real Academia, diciéndole que está bien que se haya hecho propuesta para consiliario hasta no haberse nombrado administrador general para el Tribunal de Minería. Flórez y Antonio Bonilla (rúbricas). Junio 20 de 1789.

553. Oficio de la junta a don Antonio Porlier (duplicado) reativo a los nombramientos de consiliarios. Junio 26 de 1789.

554. Oficio del virrey Revillagigedo a la Real Junta de la Academia, informándole que el rey se ha dignado aprobar los nombramientos de consiliarios, de don Fausto de Elhuyar, don Miguel Constansó y don Bernardo Bonavía, y que se tenga en cuenta para las próxi- 
mas vacantes a don Francisco Fernández de Córdova. El conde de Revillagigedo (rúbrica). Febrero 17 de 1790.

555. Oficio de don Bernardo Bonavía a la Real junta quedando enterado de la Real aprobación de su nombramiento como consiliario (rúbrica). Marzo 12 de 1790.

556. Minuta para los nombramientos de los consiliarios: don Bernardo Bonavía, don Fausto de Elhuyar y don Miguel Constansó. Junio 15 de 1789.

557. 1788. Oficio del Real Tribunal de Minería a la junta de gobierno para que nombre sujeto que pase a recibir los $\$ 2,000$ pesos que reconoce a réditos a favor de la academia. 13 de octubre de 1788.

558. Contestación al oficio anterior haciendo aclaraciones sobre la compra que se hizo del sitio de Nilpantongo a don Juan Velázquez de la Cadena. 7 de noviembre de 1788.

559. Acta en que se da cuenta del adeudo que tiene con la academia el Real Tribunal de Minería. 26 de noviembre de 1789.

560. Oficio de la junta de gobierno participando al excelentísimo señor viceprotector de la imposición de $\$ 50,000$ pesos sobre los fondos del Real Tribunal de Minería. 27 de abril de 1789.

560 a. Contestación de S. V. (virrey Flórez). Junio 16 de 1789.

561. Oficio del Real Tribunal de Minería contestando el recado político que se le pasó sobre el entero de los $\$ 50,000$ pesos respectivavos a la pensión de este año. 26 de marzo de 1789.

561 a. Contestación de la junta de la academia al Real Tribunal de Minería. 4 de abril de 1789.

562. Oficio del Real Tribunal de Minería sobre el reconocimiento de $\$ 50,000$ pesos de la academia impuesto a réditos. 4 de septiembre de 1790.

563. Copia de un oficio de la junta al Real Tribunal de Minería sobre el reconocimiento de $\$ 50,000$ pesos de la academia impuestos a réditos sobre los fondos de ese Real Tribunal. 29 de octubre de 1790.

564. Oficio del Real Tribunal de Minería sobre la redención de los $\$ 50,000$ pesos que reconoce a favor de la academia. 26 de agosto de 1790 .

564 a. Oficio al excelentísimo señor virrey, viceprotector dando cuenta de que el Real Tribunal de Minería ha exhibido los $\$ 50,000$ pesos que reconocía a favor de la academia. 27 de agosto de 1790 .

565. Solicitud del arquitecto don José del Mazo Avilés, sobre que se tomen y manden pagar los planos que hizo para la fábrica de la 
Capilla de Nuestra Señora del Carmen. Julio 1790. Al margen: "Se resolvió en junta de 29 de julio de 90 ".

566. Solicitud de los discípulos de matemáticas sobre los puntos que expresan para el examen de aritmética. Rúbricas: Ignacio Goycoechea. José Mariano Zaubazain. Francisco Palacios. Pedro Mar López. Luis de Martín. José Joaquín de Heredia. Angel de Menocal. Al margen: "Resuelto en la Junta del 31 de abril de 1790".

567. Instancia del director don Cosme de Acuña sobre que se le releve de la corrección en las horas de la noche, por las contadas causas que expresa. 31 de mayo de 1790. Al margen: "Resuelto favorablemente en la Junta de 28 de junio de 1790 ".

568. Representación del conserje don Diego Mestre sobre el desorden que se experimenta en la academia cuando sale a practicar algunas diligencias de su cargo. 28 de junio de 1790. Al margen: "Resuelto en la Junta de 28 de junio de 1790".

569. Representación del conserje don Diego Mestre y Pardo sobre el perjuicio que originan los carpinteros. “... a este efecto lo he dicho a Dn. Manuel Tolsá para que lo remedie, y me aconseja tome un palo y les rompa las costillas (no me hallo en esa disposición) ..." 23 de diciembre de 1793.

570. Instancia del arquitecto don José del Mazo Avilés sobre que no se permita que el director don Antonio Velázquez tome a su cargo la obra de la capilla de Nuestra Señora del Carmen por las razones que expresa. "... no estamos en el siglo de sujetarnos a la autoridad sino a las leyes de la razón." Al margen: "Resuelto en Junta de 28 de junio de 1790".

571. Copia de un oficio en que se dice haber acordado suspender a don José del Mazo Avilés del grado y ejercicio de Académico de Mérito, en junta del 20 de noviembre de 1797.

572. Instancia del académico supernumerario don Esteban González sobre que se le incluya en la lista de avaluadores de fincas. Al margen: "Resuelto en la junta de 22 de diciembre de 1790 se le incluyó en la lista."

573. Solicitud de don José Martín Ortiz sobre que se le nombre para tasador de las obras de arquitectura. Al margen: Informe del teniente coronel de ingenieros don Miguel Constansó sobre la aptitud. 29 de noviembre de 1788. Acordado en junta de 3 de enero de 1789.

574. Solicitud de don José Mariano Falcón sobre que se le nombre y conceda permiso para ejercer las funciones de maestro en todas 
las obras de arquitectura que se ofrezcan en la Reai Aduana. 12 de junio de 1790. Al margen: Resuelto en junta de 28 de junio de 1790.

575. Expediente sobre la aprobación de los planos formados por el arquitecto don José del Mazo Avilés para la fábrica de la capilla de Nuestra Señora del Carmen; a) Solicitud de aprobación; b) Informe de Constansó. 10 de abril 1790; c) Contestación a del Mazo, señalando los defectos que tienen los planos. 26 abril 1790; d) Oficio de remisión de los planos y el informe del señor Constansó, para que los corrija del Mazo. 22 de mayo 93; e) Copia de un oficio a del Mazo, sobre abrir puertas: que presente los planos con las verdaderas dimensiones. 31 de enero de 1793.

576. Expediente sobre la aprobación de los planos formados por el arquitecto don Francisco Guerrero y T'orres para la fábrica de la parroquia de San José. a) Informe sobre el asunto de José Damián Ortiz. 14 de abril de 1790; b) Contestación a don Francisco Guerrero y Torres señaiando los defectos de los planos presentados. 26 de abril de 1790 .

577. Solicitud de don José Martín Ortiz sobre que se le conceda el grado de Académico de Mérito en el ramo de arquitectura. Noviembre 1790. Informe de Constansó. 13 de enero de 1791. Muy favorab e.

578. Solicitud de los maestros de arquitectura para que se les admita de Académicos de Mérito. 28 de abril de 1790. José García Torres. José Alvarez. Francisco Guerrero. Ignacio Castera. José Eligio Delgadillo. José Butrón. José del Mazo Avilés.

579. Solicitud de don Esteban González sobre que se le dé certificación de ser Académico Supernumerario en el ramo de arquitectura. Al margen: Resuelto en junta de 22 de diciembre de 1790.

580. Solicitud de don Rafael Joaquín de Gutiérrez sobre que se le conceda el grado de Académico en el ramo de pintura. 25 de agosto 1790. “... regalé el lienzo de cabezas del apostolado del indio José, el ratrato de Dn. José Ibarra hecho por Contreras, y el de Juan Rodríguez Juárez por sí mismo." Al margen: Resuelto en junta de 29 de enero de 1791.

581. Expediente sobre la construcción de Casas Reales y Cárceles en San Luis Potosí. 1790. Planos y elevaciones ejecutados por don Francisco Bruno de Ureña (deficientes). Informe de González Velázquez. Nuevos planos formados por don Miguel Constansó. 1790.

582. Expediente sobre construcción de Casas Reales y cárcel en el pueblo de Santa Clara de los Cobres, provincia de Valladolid. 1796. 
583. Informe del director de arquitectura don Antonio González Velázquez sobre los planos que formó para la construcción de Casas Rea es y cárceles en Zinacantepeque. 27 de agosto de 1796.

584. Expediente sobre construcción de cárceles en Xa:asingo, 1797.

585. Expediente sobre la construcción de cárcel en Apazingo, 1799.

586. Expediente sobre la aprobación de los planos formados por el arquitecto don José García de Torres para la fábrica de unas casas en la calle del León. Informe sobre los planos de don Antonio González Velázquez. Mayo 29 de 1790.

587. Expediente sobre la so icitud para una pensión vacante en la sala de arquitectura de la Real Academia, por don José Joaquín de Heredia. Febrero 1790.

588. Expediente sobre la renuncia que hizo José Luis Marenco de la pensión, en el ramo de pintura. Febrero 1790. Con el edicto para su provisión. Marzo 1790.

589. Oficio de don Antonio González Velázquez a la junta de la academia, sobre ayuda de José Gutiérrez y Heredia para ejecutar unos planos, pues no tiene bien la vista desde su arribo a México. Pide que el trabajo se le pague extra. 29 de abril de 1790.

590. Oficio de los pensionados de pintura: José Gutiérrez, José María Vázquez y Manuel García, pidiendo se les compren los cuadros donde han de pintar, pues su pensión no les alcanza para ello. 1790.

591. Carta al señor Fernando Mangino pidiéndole un retrato del señor don Carlos III, de buena memoria y otro suyo. Se pedía una copia del retrato de Carlos III pintado por Francisco Bayer, Mariano Maella o Francisco Goya, pues no había aquí de donde sacar una buena copia. También piden un retrato de Mangino “... ejecutado por una mano hábil y diferente de la que haga el de S. M. difunto; pues conviene que haya en la Academia obras de varios profesores célebres para que estos discípu’os los conozcan." 26 de noviembre de 1790.

592. Oración inicial que en la apertura de la nueva aula de matemáticas en la Real Academia de San Carlos de esta Imperial Corte de Nueva España dijo su director don Diego Guadaiajara y Tel’o, a noche del día 2 de enero de 1790.

593. Solicitud del modelo José Antonio Montes sobre que se le paguen los cuatro reales de su asignación cuando esté enfermo. 27 de septiembre de 1790.

594. Solicitud de los modelos Eusebio Tejedor y Antonio Montes sobre que se les continúc su asignación en los mismos términos que la han gozado hasta aquí. 2 de enero de 1790. 
595. Oficio de la ciudad de México acompañando las medallas que hizo acuñar en la proclamación de Carios IV. 18 de enero de 1790.

596. Renuncia que hizo Manuel Muñoz de la pensión que obtenía en el ramo de arquitectura. 27 de septiembre de 1790.

597. Expediente sobre la provincia de pensión vacante en el ramo de arquitectura por renuncia de Manuel Muñoz. 17 de enero de 1791.

598. Expediente sobre la provisión de una pensión en el ramo de arquitectura, vacante por renuncia de Luis Martín. 1789-1790.

599. Solicitud de José Antonio Montes sobre que se le conceda la plaza de modelo vacante. Junio de 1790.

600. Solicitud de don Luis de Tola y Salcedo sobre que se le dé certificación de haber sido examinado en aritmética inferior. Noviembre de 1790.

601. Solicitud del director de matemáticas don Diego Guadalajara y Tello sobre que se dé. a imprimir por suscripción el curso de aritmética inferior que ha dictado a sus discípulos. Septiembre de 1790.

602. Expediente sobre José Luciano Castañeda, del ramo de pintura. 1790. a) Certificado de don Ginés de Andrés y Aguirre, 27 de mayo de $1790 ; b)$ Acta de bautizo (parroquia de San José en Toluca); c) Solicitud de pensión para la vacante que dejó Luis Marenco.

603. Solicitud del marqués del Apartado sobre que se le permita abrir una ventana en la pared de su casa que corresponde al solar de Nilpantongo. Junio de 1790.

604. Expedicnte de Mariano Pantaleón Reyes, del ramo de pintura 1790. Originario de la ciudad de León de Nicaragua. a) Solicitud de pensión, mayo 1790 ; b) Constancia del vicario de Santa Cruz; c) Certificado de don Ginćs de Andrés y Aguirre, mayo. 1790.

605. Solicitud de pensión, en el ramo de pintura, por don José Scvero Arzeo, español, natural del Real de Minas de Santa María de la Ycsca, obispado de Guadalajara. 1790.

606. Solicitud de pensión, en el ramo de pintura por don José María Duque. a) Certificado de don Ginés de Andrés y Aguirre, mayo. $1790 ; b)$ Solicitud.

607. Solicitud de pensión en el ramo de pintura por don Agustín Lovis. a) Solicitud; b) Certificado de don Cosme de Acuña y Troncoso, mayo 1790 .

608. So icilud de pensión en el ramo de pintura por don José Manuel Pérez de Ávila. 1790. a) Solicitud; b) Certificado de don Cosme de Acuña y Troncoso, mayo 1790. 
609. Solicitud de pensión, en el ramo de grabado en hueco, por don Mariano Tirado, español, natural del pueblo de Tlaxiaco, obispado de Oaxaca. 1790. a) Solicitud; b) Fe de bautismo.

610. Solicitud del cura de la parroquia de San José sobre que se comisione al director don Antonio González Velázquez para que cuide que la obra de la parroquia se ejecute con arreglo a los p anos. Agosto, 1790.

611. Expediente sobre la aprobación de los planos formados por el arquitecto don José García de Torres para la fábrica de unas casas en la calle de Santo Domingo y de la Pila Seca. Septiembre 1790.

613. Oficio de don José Antonio Porlier, a don Manuel Tolsá (en Cádiz) dándole aviso de que ya están listos para su embarque 66 cajones. conteniendo varios modelos, figuras libros y otros útiles de los que tiene pedidos la Real Academia. Madrid, 16 de septiembre de 1790.

614. Oficio del virrey (conde de Revillagigedo) a don Antonio Porlier, insertando la Real Orden de 23 de fcbrero, que participa haber recibido los $\$ 13,000$ que se remitieron a España para compra de útiles. 31 de mayo de 1790 .

615. Remisión de la representación de don Nicolás de Bargas, vecino de Irapuato, con la demostración geométrica de la cuadratura del círculo. Oficio del virrey (conde de Revillagigedo), a la Real Academia. 27 de octubre de 1790 .

616. Informe de la junta sobre el ramo de pintura (borrador) al virrey. 2 de enero de 1790. Acudían 80 jóvenes por la noche. Dicen qu: el estudio podría malograrse si Acuña se ausentase y don Ginés Andrés y Aguirre, que no goza de mucha salud recayese.

617. Orden de S. E. (conde de Revillagigedo) para que se entregue al director general don Gerónimo Antonio Gil el papel de marca que necesite para los fines que expresa y la respuesta del señor presidente. Marzo de 1790.

618. Informe que hizo para acuerdo de la junta de gobierno, el director general don Gerónimo Antonio Gil, sobre el modo de mejorar el método de los estudios en la academia. 30 de enero de 1790 (muy interesante).

618 a. Resumen: Don Gerónimo Antonio Gil propone: Estudio y documentos. Vaciados de estatuas de la antiguiedad, pinturas, estampas, bajorrelicves. Colección de principios perfilados y sombreados de ojos, bocas, narices, orejas, cabezas, pies, manos y figuras. Obligación de los directores. En la arquitectura es necesario que el director de ella haga los principios... A'gunos jóvenes capaces para ser Académicos de Mćrito. Obligar a Fabregat a recibir discípulos aun- 
que no sean pensionados, para que aprendan grabado y si por enfermedad del director no es esio posible el propio Gil se obliga a enseñar es. Evitar los corrillos y juntas de conversación de los maestros que dan mal ejempio; no corrigen bien los trabajos de los alumnos, eicétera, trae a co ación el artículo $3^{\circ}$ de los estatutos. Que los discípu os y pensionados de la sala del natural tengan consideración de los natura'es, que están desunidos en su cuarto, y que no se les liaga aire pues los exponen a resfriados y quizás a la muerte.

619. So icitud de pensión, en el ramo de arquitectura de don Francisco Lindo. a) So.icitud; b) Certificado de don Antonio González Velázquez. 6 de marzo de 1790; c) Certificado de don Cosme de Acuña y Troncoso. 6 de marzo de 1790.

620. Solicitud de pensión, en el ramo de arquitectura, de don José María Duque. a) Certificado de don Antonio González Velázquez. 6 de marzo de $1790 ; b)$ Solicitud.

Gaveta 5. 1791 (números del 621 al 714).

621. Cuenta de los gastos que se erogaron en la compra de útiles para habilitar a los pensionados del grabado en hueco. 1791. a) Informe dei director doctor G. A. Gil sobre los útiles que se necesitan; b) Lista de las herramientas y utensilios entregados a los pensionados Manuel López y José María Montes de Oca.

622. Cuenta presentada por el conserje don Diego Mestre y Pardo, de la distribución que dio a los $\$ 3,200$ que se le entregaron por el señor consiliario don Antonio Basoco para la obra de la Casa del Amor de Dios. Junio 1891.

623. Cuenta de los gastos erogados en la obra de la Casa del Amor de Dios, desde el 26 de abril hasta el 30 de junio de 1791. Presentada por el conserje don Diego Mestre y Pardo.

624. Consuita de la junta de gobiemo al excelentísimo señor viceprotector (Revillagigedo) sobre tomar en arrendamiento la Casa del Amor de Dios para colocar en ella la academia, 26 de mayo de 1791, y oficio en que se aprueba esta determinación. 18 de abril de 1791 .

625. Escritura de arrendamiento que otorgó el licenciado Francisco Fernández Salazar, mayordomo de S. E. y del Hospital General de San Andrés de esta corte, de casa principal de vecindad que antes fue de la del Amor de Dios y que pertenece a dicho Hospital General en favor de la Real Academia de San Carlos de esta Nueva España para establecer en ella sus estudios, en cantidad de $\$ 1,300$ anuales. como dentro se expresa. 8 de julio de 1791. 
626. Expediente sobre la provisión del empleo de director de matemáticas en don Diego Guadalajara y Tello. Tiene agregada la instancia que posteriormente hizo sobre aumento de sueldo y confirmación de su empleo con la contestación del excelentísimo señor viceprotector (Revillagigedo). Informe de don Miguel Constansó, aprobado. 1791.

627. Oficio del Real Tribunal de Minería acompañando dos medallas de plata y una de cobre, de las que se hizo acuñar en la proclamación de nuestro augusto soberano el señor don Carlos IV. $1^{\circ}$ de diciembre de 1791.

628. Nota de los señores consiliarios y demás individuos que la componen. 1791. Presidente: don Ramón de Posada. Consiliarios: don José Ángel de Aguirre, don Antonio Barroso, don Antonio Basoco, marqués de Ciria, marqués de San Miguel de Aguayo, don Fausto de Elhuyar, don Bernardo Banavía, don Miguel Constansó. Secretario: don Antonio Piñeiro. Directores: don Gerónimo Antonio Gil, don Ginés de Andrés y Aguirre, don Antonio González Velázquez, don Joaquín Fabregat, don Manuel Tolsá. Tenientes: don José de Alcíbar, don Santiago Sandoval. Académicos de Mérito: don José Damián Ortiz, don José García de Torres, don José Ảlvarez, don Francisco Guerrero y T'orres, don Ignacio Castera, don José Butrón, don José del Mazo Avilés, don Esteban González, don Luis de Martín. Académicos Supernumerarios: don Rafael Gutiérrez, don José María Guerrero, don José María Vázquez, don José Martín Ortiz. Conserje: don Diego Mestre y Pardo.

Ciudades y villas que contribuyen para la subsistencia de la academia: México y sus regidores. Veracruz, Guanajuato, Querétaro, San Miguel el Grande, Orizaba, Córdoba.

Tribunales: El Real Tribunal de Minería.

628 a. El Real Tribunal del Consulado.

Academias: Madrid, Sevilla, Valencia, Barcelona, Cádiz y sus directores.

629. Representación de los profesores del nobilísimo arte de la pintura, acerca de que se prohíba que los "Tratantes de Pintura" tengan ejercicio. (178-85) 1791 (?) Rúbricas: José de Alcíbar, Francisco Caplera, Andrés López, Rafael Joaquín Gutiérrez, Mariano Vázquez, Juan de Sáenz, Manuel de la Serna, Manuel García.

630. Nómina de los pintores y obradores de pintura que hay en México. 23 de julio de 1791.

1. Calle de las Moras. Don Andrés López, fue uno de los directores de la academia. 
2. Calle de la Servatana. Don Rafael Gutiérrez, fue uno de los directores de la academia.

3. Calle del Relox. Don Mariano Vázquez, fue uno de los directores de la academia.

4. Calle del Relox. Don Juan Sáenz, fue uno de los directores de la academia.

5. Calle de Santa Teresa. Don Francisco Caplera, fue uno de los tenientes de director de la academia.

6. Calle de las Medinas. Don Joaquín Esquivel.

7. Calle de Capuchinas. Don José Alfaro.

8. Calle de la Cadena. Don Francisco Aguirre.

9. Calle de la Merced. Don Francisco Bravo.

10. Calle de las Escalerillas. Don Juan Figueroa.

11. Calle de Santa Teresa. Don Mariano Guerrero.

12. Calle de Santa Teresa. Don José Maín.

13. Calle de Jesús María. Don Manuel Reynoso.

14. Calle del Parque. Don José Polanco.

15. Calle de Santa Isabel. Don Miguel Ångel.

16. Calle de Santa Isabel. Don Juan Hurtado.

17. Calle de Lecuona. Don Ignacio Estrada.

18. Calle de la Amargura. Don José Ignacio Barreda.

19. Calle de la Canoa. Don José Balderrama.

20. Calle de San Ramón. Don Valentín Polanco.

21. Calle de Chavarría. Don Francisco Vilchis.

22. Calle de Chavarría. Don José Vallejo.

23. Calle de la Servatana. Don Lucas León.

24. Calle de San Pedro y San Pablo. Don Martín Gaetán.

25. Calle de Tiburcio. Don Onofre.

631. Información sobre las ordenanzas de pintores y doradores de la ciudad de México.

En 1557, siendo virrey don Luis de Velasco, los pintores y doradores pidieron al Ilustre Ayuntamiento se les formasen ordenanzas. Se hicieron y aprobaron pero habiéndose perdido su uso con el transcurso del tiempo, en el año de 1686, hicieron nueva petición al virrey, conde de Paredes, quien aprobó ordenanzas nuevas. El 17 de octubre de 1686.

Extracto de las ordenanzas antiguas (1557).

Extracto de las ordenanzas nuevas (1686). 
632. Testimonio de las ordenanzas del arte de la pintura y dorado. Año de 1791 (legajo con 104 hojas), contiene: petición de Juan López de Pareja, en nombre de todos los pintores y doradores (f.l).

Ordenanzas antiguas (1557 f. 4 vuelta).

Confirmación. 4 agosto 1557. Luis de Velasco (f. 14 vuelta).

Pregón. 9 agosto 1557 (f. 15 vuelta).

Nuevas ordenanzas. 7 diciembre 1681 (f. 16 vuelta).

Respuesta del fiscal. 30 agosto 1686 (f. 22 v.).

Parecer. 17 octubre 1686 (f. 23 vuelta).

ler. Pregón. 28 abril 1687 (f. 26).

20 Pregón. 28 abril 1687 (f. 26 vuelta).

3er. Pregón. 28 abril 1687 (f. 28).

Auto. Certificación de los pregones (f. 28 vta.).

Certificación del pregón en Toluca. 18 de abril 1698 (f. 29).

632 a. Petición. Antonio de Salcedo, español, vecino de Xochimilco (f. 29 vuelta).

Presentación de las ordenanzas en el pueblo de Capulac (f. 30 vuelta).

Auto para que se pregonen (f. 30 vuelta).

Pregón en Santiago Tianguistengo. 23 abril 1698 (f. 31).

Autos. Certificación de pregones y juramentos de guardar la ordenanza.

Petición. Sobre que los ensambladores no tomen encargos de pintura o dorado (f. 35 ).

Decreto. 6 de julio 1689 (en relación con lo anterior) (f. 35 vuelta). Auto 5 de julio 1689. Sobre la observancia de las ordenanzas (f. 36). Petición. Francisco de Axpec, en nombre de los veedores del arte de la pintura y dorado, en los autos que siguen con Pedro Maldonado, maestro ensamblador sobre la ejecución de las ordenanzas (f. 48 ).

632 b. Decreto 21 abril 1960 (sobre lo anterior) (f. 48 vuelta). Petición. Francisco Axpec, etcćtera en los autos sobre la ejecución de sus ordenanzas (f. 49).

Decreto. 11 agosto 1689 (sobre lo anterior) (f. 49 vuelta).

Petición. Francisco de Axpec, etcétera. Pedro Maldonado continúa en sus fraudes, consintiendo con Gerónimo Marín, maestro do rador, en dorar un retablo del colegio de San Ángel, parte de ćl se está dorando en casa de dicho Pedro Maldonado (f. 49 vuelta). Decreto. 30 abril 1690 (sobre lo anterior) (f. 51).

Decreto. 30 abril 1690 (sobre fraudes) (f. 53).

Depósito. Embargo de Andrés cle Roa (f. 55 vuelta). 
632 c. Certificación de Nicolás López y su hijo José tienen obrador público sin ser examinados (f. 60 vuelta).

Embargo (f. 62).

Obrador de Diego Francisco (indio). Ejerce sin ser maestro (f. 62 vuelta).

Embargo (f. 63).

Casa de Nicolás de Torres (f. 63 vuelta). Ejerce sin ser maestro. Embargo (f. 64).

Andrés de Mendoza. Ejerce sin ser maestro (f. 64 vuelta).

Embargo (f. 64 vuelta).

Auto para que se lleven a la ciudad de México a Diego Francisco y a sus oficiales que se hallan en la cárcel de Xochimilco (f. 68 vuelta).

632 d. Notoriedad al teniente general (f. 69) 1695.

Disposición del virrey marqués de Valero para que le nombren alcalde y veedores (f. 77 ) 10 de febrero 1717 .

Información del alcalde de veedores sobre la casa de Salvador de Ocampo (f. 82 vuelta).

Información del alcalde y veedores sobre la casa de Juan Marcelo Audelo, indio entallador (f. 84 vuelta).

Nota sobre que no se permita se dore en casa de Juan de Rojas. 28 de febrero 1717 (f. 86 vuelta).

Nota sobre que no se permita se dore en casa de Lucas Prieto, indio. Nota sobre que Juan de Rojas no permita se dore en su casa. Marzo 1717 (f. 87 vuelta).

Oficio al virrey sobre que se notifique nuevamente a los que han quebrantado las ordenanzas, por el largo tiempo que había pasado sin haber veedores. Abril 26 de 1717. Don Miguel Díez de la Mora (f. 89 vuelta).

632 e. Petición para que no sean multados los infractores con fecha anterior a la elección de veedores. Abril 28, 1717 (f. 9l).

Decreto. 31 mayo 1717 (f. 32 vuelta).

Petición de Juan de Rojas y Salvador de Ocampo para que se les dé 6 meses de permiso para acabar y entregar las obras que ya tienen comprometidas, sin que los molesten los veedores (f. 93).

Decreto. 2 marzo 1717 (informe al corregidor) (f. 95).

Contestación que necesita saber quiénes son los multados y por quién.

4 de marzo 1717. Don Miguel Díaz de la Mora (f. 95).

Informe sobre el asunto de Juan de Rojas y Salvador Maldonado. 12 marzo 1717 (f. 95 vuelta).

632 f. Decreto 13 de abril 1717 (f. 96 vuelta) que se lleve el memorial al corregidor. 
Notificación a Jacinto Nadal, alcalde de dorador (f. 97) 16 de abril 1717.

Información del alcalde y veedores sobre los multados 12 de junio 1717 (f. 97).

Decreto 30 de junio 1717. Como parece al señor Asesor (f. 99).

Notificación a Juan de Rojas. $1^{\text {o junio }} 1717$ (f. 99 vuelta).

Notificación a Salvador de Ocampo. Misma fecha ídem.

Notificación a Juan Marcelo. Misma fecha (f. 100).

Petición del alcalde y veedores para que se pasen los autos pendientes al corregidor (f. 100 vuelta).

Decreto. Como lo piden 3 julio 1717 (f. 101).

Petición del alcalde y veedores para que, según lo acordado, se pregonen las ordenanzas para que no se alegue desconocimiento.

632 g. 3 julio 1717 (f. 101).

Orden del corregidor para que se pregonen las ordenanzas.

8 julio 1717 (f. 102).

$1^{\text {o }}$ pregón 24 julio 1717 (f. 102).

20 pregón 24 julio 1717 (f. 102 vuelta).

39 pregón 24 julio 1717 (f. 103).

Información de Francisco de Landa en nombre del alcalde Jacinto

Nadal y Zubet sobre que desde el año 1689 se siguieron los autos sobre la observancia de las ordenanzas. Se manifiesta las penas de los transgresores y que se les cobren multas (f. 103).

Decreto 21 agosto 1717. Guárdense y cúmplase (f. 104).

Notificaciones a Juan de Rojas y Salvador de Ocampo (f. 104 vuelta).

Certificación del escribano Real Mariano de Zepeda sobre todo lo contenido en el testimonio y su concordancia con los originales. México 9 de agosto de 1791.

632 h. Nota: Este expediente debe estudiarse y publicarse en parte, sobre todo las ordenanzas mismas. Justino Fernández. 10 de enero 1943.

633. Cuenta de los derechos devengados según arancel, del testimonio de ordenanzas del arte de la pintura y dorado. De lo escrito en 104 fojas. Agosto 17 de 1791. Mariano de Zepeda.

634. Solicitud de don Bernardo y don Gabriel Gil sobre que se les conceda el grado de Académicos de Mérito en el ramo del grabado en hueco. Enero 1791.

Certificado de don Gerónimo Antonio Gil. 19 enero 1791 (en la solicitud dicen que son hijos de don Gerónimo y que pasaron a Nueva España en 1777). 
635. Solicitud de José Loreto Villanueva, sobre que se le conceda el grado de Académico de Mérito, en el ramo de arquitectura. Julio 1791.

Certificado de don Antonio González Velázquez. 3 agosto 1791. Acuerdo de la junta. 9 septiembre 1791.

636. Superior aprobación de los Académicos de Mérito, don Esteban González, don Luis Martín, don José María Vázquez y don José María Guerrero. Contiene las solicitudes individuales y la aprobación del virrey, conde de Revillagigedo. 27 octubre 1791.

637. Oficio de S. E. (Revillagigedo) acompañando la instancia de don Antonio Santa María Incháurregui, sobre que se le cree Académico de Mérito en el ramo de arquitectura, o se le nombre macstro mayor en la ciudad de Puebla, con el informe de la junta superior. 1791.

638. Nota de los libros que componen la Biblioteca de la Real Academia de San Carlos. 1791.

639. Nota de los muebles que llevó don Josć Marrugat del Colegio de San Andrés. 1791.

640. Nota sobre medallas y monedas.

641. Recibo por $\$ 10$ firmado José María Zamarripa. 1788.

642. Recibo por $\$ 175$ por sueldos, firmado Tomás de Echegaray. 1787.

643. Notas de los libros, estatuas y demás útiles que en dos remisiones vinieron de España para el uso en la academia. 1791.

644. Instancia de Cristóbal Nápoles sobre que se le conceda licencia para dirigir la construcción de las bóvedas de una iglesia en el pueblo de Tenancingo.

Certificaciones de don Francisco Antonio Guerrero y Torres, Br. José Mateo Valenzuela y don Ramón de Posada. 1791.

645. Solicitud del grabador don José Joaquín Fabregat sobre que se habilite de buriles y demás cosas necesarias a su discípulo José Huerta. 16 de marzo de 1791.

646. Instancia de don Francisco Caplera sobre que se le confiera la plaza de segundo director de pintura, vacante por la dimensión de don Cosme de Acuña, con la Real Orden en que se le concede permiso. a éste para su regreso a España.

Orden del virrey (Revillagigedo) 31 marzo 1790.

Copia de un oficio de la academia al virrey en que se dice no so puede nombrar sucesor de Acuña hasta no saber si se va. Junio 3. 1790.

Soiicitud de Francisco Caplera (dice que Gil lo nombró en 4 de 
noviembre 1781 director mientras venían maestros de España. 18 marzo 1791.

Oficio del virrey (Revillagigedo) para que se tenga presente la solicitud 23 de marzo de 1791 .

646 a. Oficio en que la junta dice no estar enterada del asunto, pide al virrey le pase la Rcal Orden y demás. 4 abril 1791.

Oficio del virrey pasando el expediente. 8 abril 1791.

Acuerdo de la junta, enterada del permiso concedido a Acuña para regresar a España; opina que no hay pintores capaces para remplazarlo pues, ni Caplera, ni Alcíbar, ni Rafael Gutiérrez reúnen las condiciones necesarias; piden que se mande nuevo director, de España. 1 ? mayo de 1791.

647. Representación del director de matemáticas don Diego Guadalajara sobre la indispensable necesidad de nombrar decuriones o substitutos que le auxilien. 29 agosto 1791. Proporciona una lista de los sujetos.

648. Renuncia que hizo don Francisco Caplera del empleo de teniente director de pintura. 22 dicicmbre 1790 .

Oficio del virrey (Revillagigedo): enterado. 5 de enero de 1791.

Oficio de la academia al virrey, enterada de la renuncia de Caplera y mientras se da aviso a los profesores que fuesen más acreedores al puesto, que lo desempeñen don José María Vázquez y don José María Guerrero. 4 de enero de 1791.

649. Memorial del director de matemáticas sobre que se fijen rotulones participando al público que el curso de aritmética universal deberá empezar el día 16 de mayo. 1791.

650. Representación de la junta de policía sobre los inconvenientes que prepara la colocación de dos cruces de piedra sobre globos de la propia materia, que deben coronar las torres de la Santa Iglesia Metropolitana. Marzo-mayo 1791.

651. Superior Orden de S. E. (Revillagigedo) participando haber prevenido al señor intendente de Veracruz facilite al director de escultura don Manuel Tolsá, los auxilios necesarios para conducir a esta capital los útiles que conduce con destino a la academia. Mayo de 1791.

652. Oficio a S. E. (Revillagigedo) del presidente de la academia, quedando enterado de la Real Orden respecto a los útiles que vienen a cargo de don Manuel Tolsá. 27 de julio de 1791.

653. Expediente formado para el entero en Cajas Reales de los $\$ 16,794$ suplidos en Veracruz al director de escultura don Manuel Tolsá para la conducción de los cajones de estatuas y demás útilcs desde aquel puerto hasta esta ciudad. 1792. 
654. Instancia de los pensionados de escultura sobre que se les dé alguna gratificación por el trabajo que emprendieron en ayudar a montar las estatuas. José López, Juan Fortés, Pedro Patiño Ixtolinque. 1793.

655. Instancia del director de escultura don Manuel Tolsá sobre que se le suplan $\$ 1,000$ para pagar los empeños que contrajo en su viaje. 1791 .

656. Expediente sobre el entero de $\$ 1,000$ en las Cajas Reales: los $\$ 750$ suplidos en Cádiz del caudal de la Real Hacienda al director de escultura don Manuel Tolsá para su transporte y conducción a este reino: y los $\$ 250$ restantes por los derechos, a razón de peso fuerte por sencillo. 1791 .

657. Solicitud de los pensionados en el ramo de escultura, Pedro Patiño, Juan López y Juan de la Cruz, sobre que se les faciliten los útiles necesarios para el ejercicio de su arte. Julio de 1791.

658. Solicitud de los jóvenes don Juan Sánchez y don José Gutiérrez sobre que se les habilite de ropa (presenta lista de la que necesita). 1791 .

659. Cálculo del costo que puede tener la habitación de la galería de estatuas y sala de pintura, formado por el director don Antonio González Velázquez. Octubre de 1791.

660. Expediente formado sobre el nombramiento de profesores, que valúen las obras de pintura, escultura y arquitectura. 1791. Pintura: director don Ginés de Aguirre, don Cosme de Acuña, don José Alcíbar, don Francisco Caplera, don Rafael Gutićrrez. Escultura: don Santiago Sandoval y don Ignacio Sandoval. Arquitectura: director don Antonio González Velázquez, don José Damián Ortiz de Castro, don Ignacio Castera, don Francisco Guerrero y Torres, don José del Razo, don Esteban González. Grabado en hueco: director general don Gerónimo Antonio Gil. Grabado en lámina: director don José Joaquín Fabregat. Enero 1791.

661. Solicitud de don Diego de Guadalajara y Tello para que se fije en la pared del frontis de la Real Academia una lápida de tecali con el siguiente sagrado verso:

Señor, y Dios mío

Vuestro nombre sacrosanto

sea en todo el Orbe bendito,

y todos con dulce canto

Digan levantando el grito:

¡Oh Dios Santo, Santo, Santo! 1791. 
662. Solicitud del pensionado don José María Montes de Oca sobre que se le permita hacer su oposición en las ramas de escultura o dibujo.

663. Solicitud del Académico de Mérito don Joaquín de Heredia pidiendo que se pase aviso a la junta municipal de esta ciudad, de su nombramiento. 1791 .

664. Instancia de don Pedro Manuel Tapiz sobre que se dé certificación de su aplicación y progreso en la matemática. 1791.

665. Instancia de don José María Arrospide acerca de que se le restituya la pensión en el ramo de arquitectura. Con certificado de don Antonio González Velázquez. 1791.

666. Expediente sobre los planos formados por el arquitecto don Francisco Antonio Guerrero y Torres para el reedificio de unas casas en la calle de Balvanera. 1791.

667. Expediente formado para la aprobación de los planos de una casa propia del Convento de Religiosas de Regina, en la calle de la Cruz Verde. 1791.

668. Expediente sobre nombramiento de maestros que deben enseñar el dibujo de figura y delineaciones en el Colegio Metálico del Real Tribunal de Minería. 1791.

Se nombró a don Esteban González y a don Bernardo Gil para maestros de dibujo y arquitectura en el seminario de metalurgia.

669. Solicitud de don Miguel Villerías, sobre que se le aumente el honorario que goza para la recaudación de los arrendamientos del solar de Milpantongo. 1791.

670. Solicitud del pensionado don José María Vázquez sobre que se le dé alguna gratificación por los retratos que pintó de los excelentísimos señores don Manuel Antonio Flórez y don Matías de Gálvez. 1791.

671. Solicitud de don Pedro Patiño Ixtolinque sobre que se le dé certificación de ser pensionado en el ramo de escultura. 1791.

672. Solicitud de don Ginés de Aguirre sobre que se le permita tomar a su cargo la obra de pintar al fresco la bóveda del bautisterio del Sagrario de la Santa Iglesia Metropolitana. Marzo 28 de 1791. "que habiéndole comisionado para pintar a el fresco la bóveda del bautisterio de El Sagrario, obra que puede serles útiles a los pensionados de esta Academia, pues hasta la presente no se ha ejecutado semejante método en América; porque sin embargo de haberse hecho algo, no es el verdadero fresco, sujeto a las buenas y precisas máximas que semejante pintura requiere; ni tampoco los discípulos han logrado ver cómo se ejecuta..." 28 de marzo de 1791. Ginés de Andrés y de Aguirre. 
673. Aviso al señor alcalde decano de la Real Sala del Crimen don Luis de Chávez y Mendoza, acerca de que uno de los porteros de la Real Academia dio dos heridas a un pensionado. 19 de mayo de 1791.

674. Carta del juez don Antonio Montero y Velarde a don Ramón de Posada, acerca de que se nombren dos o tres sujetos de la academia condiscípulos del pintor José Antonio Polanco, para no demorar la causa criminal que está formando al susodicho. 9 de marzo de 1791.

675. Oficio del alcalde don Luis de Chávez y Mendoza al señor don Ramón Posada, expresando tener conocimiento de las heridas causadas por un portero de la Academia a uno de los pensionados y que ya dispuso la traslación del reo a la cárcel de la corte. 20 de mayo de 1791.

676. Oficio al excelentísimo señor virrey conde de Revillagigedo a fin de que se sirva mandar se circule orden a todos los señores intendentes para que dispongan que los maestros de obras titulados ocurran a examinarse en el término que se expresa. 24 de septiembre de 1794.

677. Carta de don Ramón de Posada a don Antonio María Fernández dándole las gracias por el retrato del serenísimo señor Príncipe de Asturias que ha regalado e informándole que le remite una copia del mismo por el conducto del cadete don Andrés Amat de Tortosa que pasa a España en compañía del conde de Casa Flores. 7 de julio de 1791 .

678. Oficio del señor presidente sobre la utilidad que resultara de que el pensionado en ramo de arquitectura don José Gutićrrez acompane al teniente de guardias españolas don Antonio Pineda en el viaje que está por hacer al Real de Guanajuato y otras partes. 21 de agosto de 1791 (al señor conde de Revillagigedo).

679. Impreso comunicando a la Real Academia la Real Orden de 24 de marzo de 1791. La Real Orden se refiere a que a don Antonio Porlier se le ha concedido Título de Castilla, para él y sus hijos y sucesores, con la denominación de marqués de Baxamar (el conde de Revillagigedo, rúbrica). 6 de julio de 1791.

680. Oficio enviando a su excelencia, el conde de Revillagigedo el estado de entrada y salida de caudales de la Real Academia 11 de febrero de 1791.

681. Contestación del conde de Revillagigedo a la junta de gobierno de la Real Academia, diciendo que queda enterado por el estado enviado de la entrada y salida de caudales. 12 de febrero de 1791. 
682 al 691 cancelados.

692. Oficio al señor conde de Revillagigedo a la Real Academia, ordenando que los oficios que se le envíen vayan dirigiclos a la oficina a que el asunto corresponda. 18 de julio de 1791.

693. Oficio tomando nota del anterior (692). 27 de julio de 1791.

694. Oficio del señor conde de Revillagigedo acerca de que la junta superior de gobierno informe sobre la actividad, aplicación y conducta de don Antonio Piñeiro, en el empleo que ha servido a la academia desde el año de $1785.1^{\circ}$ enero 1794.

695. Oficio del señor conde de Revillagigedo acerca de la forma de tramitación de oficios (véanse números 692 y 693). 22 de julio de 1791.

696. Oficio del señor conde de Revillagigedo acerca de que han sido de su aprobación los nombramientos de don Esteban González y don Bernardo Gil para maestros que enseñen en el Colegio Metálico del Real Tribunal de Minería, la delineación de planos de edificios, máquinas, diseños geográficos, hornos, vistas de campo y el dibujo de figura. 26 de diciembre de 1791.

697. Oficio acerca de cómo deben cubrirse los gastos originados por el transporte de don Manuel Tolsá, una sobrina y un criado, así como de los cajones y barriles con útiles para la Real Academia, que llegaron al puerto de Veracruz en la fragata de guerra nombrada Santa Paula, al mando del teniente de navío, don Miguel Cuadrado, que partió del puerto de Cádiz. 14 de mayo de 1791.

698. Solicitud de pensión en el ramo de arquitectura, por don José María Pulgar. 27 de marzo de 1791. Certificación de don Antonio González Velázquez.

699. Renuncia que hizo don José María Pulgar de la pensión que obtenía. 31 de enero de 1796 (véase 698).

700. Solicitud de pensión en el ramo de arquitectura de don Manuel Bustamante. Marzo 1791. Certificaciones de don Antonio González Velázquez.

701. Expediente sobre los planos formados por el arquitecto don Francisco Guerrero y Torres para la fábrica de una casa en la calle de Mesones. Abril 1791.

702. Expediente sobre la aprobación de los planos formados por el arquitecto don José Joaquín García Torres para la construcción de una casa en la calle de Medinas. Diciembre 1791.

703. Oficio del señor conde de Revillagigedo a don Ramón de Posada comunicándole lo que le dice el señor marqués de Bajamar en la Real Orden de 18 de abril de 1791. 
531. Renuncia que hizo de su pensión en el ramo de pintura, Agustín Cerezo. Al pie: Se admitió en junta de 9 de febrero de 89 y se nombró al supernumerario Luis Martínez (?).

532. Representación del director de matemáticas don Diego Guadalajara sobre las horas en que ha de dar sus lecciones a los pensionados y demás discípulos con el edicto o noticia que se le dio al público. 1789. Legajo conteniendo los documentos números 533 y 543.

533. Edicto (copia) de la junta superior de gobierno de la Real Academia avisando que el próximo mes de enero se abrirá el aula de matemáticas a la dirección de don Diego Guadalajara Tello. Diciembre 10 de 1789 .

534. Representación de don Diego Guadalajara sobre las horas en que ha de dar sus lecciones y la necesidad de que se le aumente el sueldo. Al margen: acordado en junta de 18 de septiembre de 1789.

535. Expediente formado sobre la asistencia del teniente de pintura don Francisco Caplera de la academia, en los sábados por la noche. 1789. Legajo conteniendo los documentos números 536 y 537.

536. Oficio de don Francisco Caplera sobre su asistencia a la academia (al principio el acuerdo de Posada para que informe Gil). marzo 3 de 1789 (rúbrica).

537. Informe de don Gerónimo Antonio Gil sobre la asistencia de Caplera apoyando su representación. Marzo 12 de 1789 (rúbrica) (acordada en junta de 4 de abril concediendo la gracia que se solicita).

538. Expediente formado a instancia del conserje don Diego Mestre y Pardo sobre que se le conceda licencia de curarse y se nombre sujeto que lo sustituya durante su enfermedad. 1789. Legajo conteniendo los documentos números 539, 540 y 541 .

539. Oficio de don Diego Mestre y Pardo declarando que por enfermedad no puede asistir a la academia y pide permiso para ausentarse mientras se restablece. Junio 12 de 1789 (rúbrica).

540. Certificación del licenciado Manuel Moreno sobre la enfermedad de don Diego Mestre (rúbrica). Junio 10 de 1789.

541. Oficio de don Diego Mestre diciendo que de acuerdo con lo dispuesto por la junta y mientras se encuentra enfermo, dejará en su lugar a su hijo Manuel (rúbrica). Junio 13 de 1789.

542. Dos certificaciones dadas por don Manuel Moreno y por don José Anastasio Pardo, profesores de cirigía, que acreditan la indisposición que padece el conserje clon Diego Mestre. 1791. Legajo conteniendo los documentos números 543 y 544 . 
543. Certificado del licenciado Manuel Moreno relativo a la enfermedad de don Diego Mestre. Al margen un acuerdo de Posada (rúbrica). Enero $1^{\circ}$ de 1791.

544. Certificado de don José Anastasio Pardo relativo a la enfermedad de don Diego Mestre (rúbrica). Marzo 8 de 1791.

545. Expediente sobre nombramientos de consi iarios hechos el año de 1789 en los S. S. Don Fausti de Elhuyar, don Miguel de Constansó y don Bernardo de Bonavía. 1789-1790. Legajo conteniendo los documentos números 546 a 556 , inclusive.

546. Oficio de la junta al virrey informándole que quedó vacante el empleo de consiliario que tenía don Ramón de Posada, por causa de su ascenso, y proponiendo a: $1^{\circ}$ Don Francisco Fernández de Córdova; $2^{\circ}$ Don Miguel Constansó, y $3^{\circ} \mathrm{El}$ conde de Santiago. Mayo 26 de 1789 (copia).

547. Oficio de la junta al virrey, informándole haber quedado vacante el empleo de consiliario que tenía don Joaquín Velázquez de León, por fallecimiento, y proponiendo para ocuparlo a: $1^{\text {o }}$ Don Fausto de Elhuyar; 2․ Don Ramón Luis de Liceaga, y $3^{\circ}$ El marqués del Apartado. Mayo 26 de 1789 (copia).

548. Oficio de la junta al virrey informándole haber quedado vacante el empleo de consiliario que tenía don Francisco Crespo, por fallecimiento de éste y proponiendo a: $1^{\circ}$ Bernardo Bonavía; $2^{\circ} \mathrm{El}$ marqués de Uluapa, y $3^{\circ}$ Don Joaquín Romero Caamaño. Mayo 26 de 1789 (copia).

549. Oficio del virrey Flores a la junta informándole haber hecho nombramiento para consiliario en favor de don Bernardo Bonavía. Flórez (rúbrica). Junio 5 de 1789.

550. Oficio del virrey Flores a la junta informándole haber hecho nombramiento para consiliario en favor de don Fausto de Elhuyar. Flórez (rúbrica). Junio 5 de 1789.

552. Oficio del virrey Flores al presidente de la Real Academia, diciéndole que está bien que se haya hecho propuesta para consiliario hasta no haberse nombrado administrador general para el Tribunal de Minería. Flórez y Antonio Bonilla (rúbricas). Junio 20 de 1789.

553. Oficio de la junta a don Antonio Porlier (duplicado) réativo a los nombramientos de consiliarios. Junio 26 de 1789.

554. Oficio del virrey Revillagigedo a la Real Junta de la Academia, informándole que el rey se ha dignado aprobar los nombramientos de consiliarios, de don Fausto de Elhuyar, don Miguel Constansó y don Bernardo Bonavía, y que se tenga en cuenta para las próxi- 
mas vacantes a don Francisco Fernández de Córdova. El conde de Revillagigedo (rúbrica). Febrero 17 de 1790.

555. Oficio de don Bernardo Bonavía a la Real junta quedando enterado de la Real aprobación de su nombramiento como consiliario (rúbrica). Marzo 12 de 1790.

556. Minuta para los nombramientos de los consiliarios: don Bernardo Bonavía, don Fausto de Elhuyar y don Miguel Constansó. Junio 15 de 1789.

557. 1788. Oficio del Real Tribunal de Minería a la junta de gobierno para que nombre sujeto que pase a recibir los $\$ 2,000$ pesos que reconoce a réditos a favor de la academia. 13 de octubre de 1788.

558. Contestación al oficio anterior haciendo aclaraciones sobre la compra que se hizo del sitio de Nilpantongo a don Juan Velázquez de la Cadena. 7 de noviembre de 1788.

559. Acta en que se da cuenta del adeudo que tiene con la academia el Real Tribunal de Minería. 26 de noviembre de 1789.

560. Oficio de la junta de gobierno participando al excelentísimo señor viceprotector de la imposición de $\$ 50,000$ pesos sobre los fondos del Real Tribunal de Minería. 27 de abril de 1789.

560 a. Contestación de S. V. (virrey Flórez). Junio 16 de 1789.

561. Oficio del Real Tribunal de Minería contestando el recado político que se le pasó sobre el entero de los $\$ 50,000$ pesos respectivavos a la pensión de este año. 26 de marzo de 1789.

561 a. Contestación de la junta de la academia al Real Tribunal de Minería. 4 de abril de 1789.

562. Oficio del Real Tribunal de Minería sobre el reconocimiento de $\$ 50,000$ pesos de la academia impuesto a réditos. 4 de septiembre de 1790 .

563. Copia de un oficio de la junta al Real Tribunal de Minería sobre el reconocimiento de $\$ 50,000$ pesos de la academia impuestos a réditos sobre los fondos de ese Real Tribunal. 29 de octubre de 1790.

564. Oficio del Real Tribunal de Minería sobre la redención de los $\$ 50,000$ pesos que reconoce a favor de la academia. 26 de agosto de 1790 .

564 a. Oficio al excelentísimo señor virrey, viceprotector dando cuenta de que el Real Tribunal de Minería ha exhibido los $\$ 50,000$ pesos que reconocía a favor de la academia. 27 de agosto de 1790 .

565. Solicitud del arquitecto don José del Mazo Avilés, sobre que se tomen y manden pagar los planos que hizo para la fábriea de la 
Capilla de Nuestra Señora del Carmen. Julio 1790. Al margen: "Se resolvió en junta de 29 de julio de $90^{\prime \prime}$.

566. Solicitud de los discípulos de matemáticas sobre los puntos que expresan para el examen de aritmética. Rúbricas: Ignacio Goycoechea. José Mariano Zaubazain. Francisco Palacios. Pedro Mar López. Luis de Martín. José Joaquín de Heredia. Ángel de Menocal. Al margen: "Resuelto en la Junta del 31 de abril de 1790".

567. Instancia del director don Cosme de Acuña sobre que se le releve de la corrección en las horas de la noche, por las contadas causas que expresa. 31 de mayo de 1790. Al margen: "Resuelto favorablemente en la Junta de 28 de junio de $1790^{\prime \prime}$.

568. Representación del conserje don Diego Mestre sobre el desorden que se experimenta en la academia cuando sale a practicar algunas diligencias de su cargo. 28 de junio de 1790. Al margen: "Resuelto en la Junta de 28 de junio de 1790".

569. Representación del conserje don Diego Mestre y Pardo sobre el perjuicio que originan los carpinteros. “... a este efecto lo he dicho a Dn. Manuel Tolsá para que lo remedie, y me aconseja tome un palo y les rompa las costillas (no me hallo en esa disposición) ..." 23 de diciembre de 1793.

570. Instancia del arquitecto don José del Mazo Avilés sobre que no se permita que el director don Antonio Velázquez tome a su cargo la obra de la capilla de Nuestra Señora del Carmen por las razones que expresa. ". . . no estamos en el siglo de sujetarnos a la autoridad sino a las leyes de la razón." Al margen: "Resuelto en Junta de 28 de junio de 1790".

571. Copia de un oficio en que se dice haber acordado suspender a don José del Mazo Avilés del grado y ejercicio de Académico de Mérito, en junta del 20 de noviembre de 1797.

572. Instancia del académico supernumerario don Esteban González sobre que se le incluya en la lista de avaluadores de fincas. Al margen: "Resuelto en la junta de 22 de diciembre de 1790 se le incluyó en la lista."

573. Solicitud de don José Martín Ortiz sobre que se le nombre para tasador de las obras de arquitectura. Al margen: Informe del teniente coronel de ingenieros don Miguel Constansó sobre la aptitud. 29 de noviembre de 1788. Acordado en junta de 3 de enero de 1789.

574. Solicitud de don José Mariano Falcón sobre que se le nombre y conceda permiso para ejercer las funciones de maestro en todas 
las obras de arquitectura que se ofrezcan en la Real Aduana. 12 de junio de 1790 . Al margen: Resuelto en junta de 28 de junio de 1790.

575. Expediente sobre la aprobación de los planos formados por el arquitecto don José del Mazo Avilés para la fábrica de la capilla de Nuestra Señora del Carmen; a) Solicitud de aprobación; b) Informe de Constansó. 10 de abril 1790; c) Contestación a del Mazo, señalando los defectos que tienen los planos. 26 abril 1790; d) Oficio de remisión de los planos y el informe del señor Constansó, para que los corrija del Mazo. 22 de mayo 93; e) Copia de un oficio a del Mazo, sobre abrir puertas: que presente los planos con las verdaderas dimensiones. 31 de enero de 1793.

576. Expediente sobre la aprobación de los planos formados por el arquitecto don Francisco Guerrero y Torres para la fábrica de la parroquia de San José. a) Informe sobre el asunto de José Damián Ortiz. 14 de abril de 1790; b) Contestación a don Francisco Guerrero y Torres señaiando los defectos de los planos presentados. 26 de abril de 1790 .

577. Solicitud de don José Martín Ortiz sobre que se le conceda el grado de Académico de Mérito en el ramo de arquitectura. Noviembre 1790. Informe de Constansó. 13 de enero de 1791. Muy favorab e.

578. Solicitud de los maestros de arquitectura para que se les admita de Académicos de Mérito. 28 de abril de 1790. José García Torres. José Alvarez. Francisco Guerrero. Ignacio Castera. José Eligio Delgadillo. José Butrón. José del Mazo Avilés.

579. Solicitud de don Esteban González sobre que se le dé certificación de ser Académico Supernumerario en el ramo de arquitectura. Al margen: Resuelto en junta de 22 de diciembre de 1790.

580. Solicitud de don Rafael Joaquín de Gutiérrez sobre que se le conceda el grado de Académico en el ramo de pintura. 25 de agosto 1790. “... regalé el lienzo de cabezas del apostolado del indio José, el ratrato de Dn. José Ibarra hecho por Contreras, y el de Juan Rodríguez Juárez por sí mismo." Al margen: Resuelto en junta de 29 de enero de 1791 .

581. Expediente sobre la construcción de Casas Reales y Cárceles en San Luis Potosí. 1790. Planos y elevaciones ejecutados por don Francisco Bruno de Ureña (deficientes). Informe de González Velázquez. Nuevos planos formados por don Miguel Constansó. 1790.

582. Expediente sobre construcción de Casas Reales y cárcel en el pueblo de Santa Clara de los Cobres, provincia de Valladolid. 1796. 
583. Informe del director de arquitectura don Antonio González Velázquez sobre los planos que formó para la construcción de Casas Rea es y cárceles en Zinacantepeque. 27 de agosto de 1796.

584. Expediente sobre construcción de cárceles en Xa.asingo, 1797.

585. Expediente sobre la construcción de cárcel en Apazingo, 1799.

586. Expediente sobre la aprobación de los planos formados por el arquitecto don José García de Torres para la fábrica de unas casas en la calle del León. Informe sobre los planos de don Antonio González Velázquez. Mayo 29 de 1790.

587. Expediente sobre la so.icitud para una pensión vacante en la sala de arquitectura de la Real Academia, por don José Joaquín de Heredia. Febrero 1790.

588. Expediente sobre la renuncia que hizo José Luis Marenco de la pensión, en el ramo de pintura. Febrero 1790. Con el edicto para su provisión. Marzo 1790.

589. Oficio de don Antonio González Velázquez a la junta de la academia, sobre ayuda de José Gutiérrez y Heredia para ejecutar unos planos, pues no tiene bien la vista desde su arribo a México. Pide que el trabajo se le pague extra. 29 de abril de 1790.

590. Oficio de los pensionados de pintura: José Gutiérrez, José María Vázquez y Manuel García, pidiendo se les compren los cuadros donde han de pintar, pues su pensión no les alcanza para ello. 1790.

591. Carta al señor Fernando Mangino pidiéndole un retrato del señor don Carlos III, de buena memoria y otro suyo. Se pedía una copia del retrato de Carlos III pintado por Francisco Bayer, Mariano Maella o Francisco Goya, pues no había aquí de donde sacar una buena copia. También piden un retrato de Mangino “... ejecutado por una mano hábil y diferente de la que haga el de S. M. difunto; pues conviene que haya en la Academia obras de varios profesores célebres para que estos discípu.os los conozcan." 26 de noviembre de 1790.

592. Oración inicial que en la apertura de la nueva aula de matemáticas en la Real Academia de San Carlos de esta Imperial Corte de Nueva España dijo su director don Diego Guadaiajara y Tel.o, a noche del día 2 de enero de 1790.

593. Solicitud del modelo José Antonio Montes sobre que se le paguen los cuatro reales de su asignación cuando esté enfermo. 27 de septiembre de 1790 .

594. Solicitud de los modelos Eusebio Tejedor y Antonio Montes sobre que se les continúe su asignación en los mismos términos que la han gozado hasta aquí. 2 de enero de 1790. 
595. Oficio de la ciudad de México acompañando las medallas que hizo acuñar en la proclamación de Carios IV. 18 de enero de 1790.

596. Renuncia que hizo Manuel Muñoz de la pensión que obtenía en el ramo de arquitectura. 27 de septiembre de 1790 .

597. Expediente sobre la provincia de pensión vacante en el ramo de arquitectura por renuncia de Manuel Muñoz. 17 de enero de 1791.

598. Expediente sobre la provisión de una pensión en el ramo de arquitectura, vacante por renuncia de Luis Martín. 1789-1790.

599. Solicitud de José Antonio Montes sobre que se le conceda la plaza de modelo vacante. Junio de 1790.

600. Solicitud de don Luis de Tola y Salcedo sobre que se le dé certificación de haber sido examinado en aritmética inferior. Noviembre de 1790.

601. Solicitud del director de matemáticas don Diego Guadalajara y Tello sobre que se dé a imprimir por suscripción el curso de aritmética inferior que ha dictado a sus discípulos. Septiembre de 1790.

602. Expediente sobre José Luciano Castañeda, del ramo de pintura. 1790. a) Certificado de don Ginés de Andrés y Aguirre, 27 de mayo de $1790 ; b)$ Acta de bautizo (parroquia de San José en Toluca); c) Solicitud de pensión para la vacante que dejó Luis Marenco.

603. Solicitud del marqués del Apartado sobre que se le permita abrir una ventana en la pared de su casa que corresponde al solar de Nilpantongo. Junio de 1790.

604. Expediente de Mariano Pantaleón Reyes, del ramo de pintura 1790. Originario de la ciudad de León de Nicaragua. a) Solicitud de pensión, mayo $1790 ; b)$ Constancia del vicario de Santa Cruz; c) Certificado de don Ginés de Andrés y Aguirre, mayo. 1790.

605. Solicitud de pensión, en el ramo de pintura, por don José Severo Arzeo, español, natural del Real de Minas de Santa María de la Yesca, obispado de Guadalajara. 1790.

606. Solicitud de pensión, en el ramo de pintura por don José María Duque. a) Certificado de don Ginés de Andrés y Aguirre, mayo. $1790 ; b)$ So'icitud.

607. Solicitud de pensión en el ramo de pintura por don Agustín Lovis. a) Solicitud; b) Certificado de don Cosme de Acuña y Troncoso, mayo 1790.

608. So icitud de pensión en el ramo de pintura por don José Manuel Pérez de Avila. 1790. a) Solicitud; b) Certificado de don Cosme de Acuña y Troncoso, mayo 1790. 
609. Solicitud de pensión, en el ramo de grabado en hueco, por don Mariano Tirado, español, natural del pueblo de Tlaxiaco, obispado de Oaxaca. 1790. a) Solicitud; b) Fe de bautismo.

610. Solicitud del cura de la parroquia de San José sobre que se comisione al director don Antonio González Velázquez para que cuide que la obra de la parroquia se ejecute con arreglo a los p anos. Agosto, 1790.

611. Expediente sobre la aprobación de los planos formados por el arquitecto don José García de Torres para la fábrica de unas casas en la calle de Santo Domingo y de la Pila Seca. Septiembre 1790.

613. Oficio de don José Antonio Porlier, a don Manuel Tolsá (en Cádiz) dándole aviso de que ya están listos para su embarque 66 cajones conteniendo varios modelos, figuras libros y otros útiles de los que tiene pedidos la Real Academia. Madrid, 16 de septiembre de 1790.

614. Oficio del virrey (conde de Revillagigedo) a don Antonio Porlier, insertando la Real Orden de 23 de febrero, que participa haber recibido los $\$ 13,000$ que se remitieron a España para compra de útiles. 31 de mayo de 1790 .

615. Remisión de la representación de don Nicolás de Bargas, vecino de Irapuato, con la demostración geométrica de la cuadratura del círculo. Oficio del virrey (conde de Revillagigedo), a la Real Academia. 27 de octubre de 1790.

616. Informe de la junta sobre el ramo de pintura (borrador) al virrey. 2 de enero de 1790. Acudían 80 jóvenes por la noche. Dicen que el estudio podría malograrse si Acuña se ausentase y don Ginés Andrés y Aguirre, que no goza de mucha salud recayese.

617. Orden de S. E. (conde de Revillagigedo) para que se entregue al director general don Gerónimo Antonio Gil el papel de marca que necesite para los fines que expresa y la respuesta del señor presi-. dente. Marzo de 1790.

618. Informe quc hizo para acuerdo de la junta de gobierno, el director general don Gerónimo Antonio Gil, sobre el modo de mejorar el método de los estudios en la academia. 30 de enero de 1790 (muy interesante).

618 a. Resumen: Don Gerónimo Antonio Gil propone: Estudio y documentos. Vaciados de estatuas de la antiguiedad, pinturas, estampas, bajorrelieves. Colección de principios perfilados y sombreados de ojos, bocas, narices, orejas, cabezas, pies, manos y figuras. Obligación de los directores. En la arquitectura es necesario que el director de ella haga los principios... A'gunos jóvenes capaces para ser Académicos de Mérito. Obligar a Fabregat a recibir discípulos aun- 
que no sean pensionados, para que aprendan grabado y si por enfermedad del director no es esto posible el propio Gil se obliga a enseñar.es. Evitar los corrillos y juntas de conversación de los maestros que dan mal ejempio; no corrigen bien los trabajos de los alumnos, eccétera, trae a co ación el artículo $3^{\circ}$ de los estatutos. Que los discípu os y pensionados de la sala del natural tengan consideración de los natura'es, que están desunidos en su cuarto, y que no se les liaga aire pues los exponen a resfriados y quizás a la muerte.

619. So icitud de pensión, en el ramo de arquitectura de don Francisco Lindo. a) So.icitud; $b$ ) Certificado de don Antonio González Velázquez. 6 de marzo de $1790 ; c)$ Certificado de don Cosme de Acuña y Troncoso. 6 de marzo de 1790 .

620. Solicitud de pensión, en el ramo de arquitectura, de don José María Duque. a) Certificado de don Antonio González Velázquez. 6 de marzo de $1790 ; b$ ) Solicitud.

Gaveta 5. 1791 (números del 621 al 714).

621. Cuenta de los gastos que se erogaron en la compra de útiles para habilitar a los pensionados del grabado en hueco. 1791. a) Informe del director doctor G. A. Gil sobre los útiles que se necesitan; b) Lista de las herramientas y utensilios entregados a los pensionados Manuel López y José María Montes de Oca.

622. Cuenta presentada por el conserje don Diego Mestre y Pardo, de la distribución que dio a los $\$ 3,200$ que se le entregaron por el señor consiliario don Antonio Basoco para la obra de la Casa del Amor de Dios. Junio 1891.

623. Cuenta de los gastos erogados en la obra de la Casa del Amor de Dios, desde el 26 de abril hasta el 30 de junio de 1791. Presentada por el conserje don Diego Mestre y Pardo.

624. Consu'ta de la junta de gobiemo al excelentísimo señor viceprotector (Revillagigedo) sobre tomar en arrendamiento la Casa del Amor de Dios para colocar en ella la academia, 26 de mayo de 1791, y oficio en que se aprueba esta determinación. 18 de abril de 1791.

625. Escritura de arrendamiento que otorgó el licenciado Francisco Fernández Salazar, mayordomo de S. E. y del Hospital General de San Andrés de esta corte, de casa principal de vecindad que antes fue de la del Amor de Dios y que pertenece a dicho Hospital General en favor de la Real Academia de San Carlos de esta Nueva España para establecer en ella sus estudios, en cantidad de $\$ 1,300$ anuales,. como dentro se expresa. 8 de julio de 1791. 
626. Expediente sobre la provisión del empleo de director de matemáticas en don Diego Guadalajara y Tello. Tiene agregada la instancia que posteriormente hizo sobre aumento de sueldo y confirmación de su empleo con la contestación del excelentísimo señor viceprotector (Revillagigedo). Informe de don Miguel Constansó, aprobado. 1791.

627. Oficio del Real Tribunal de Minería acompañando dos medallas de plata y una de cobre, de las que se hizo acuñar en la proclamación de nuestro augusto soberano el señor don Carlos IV. $1^{\circ} \mathrm{de}$ diciembre de 1791.

628. Nota de los señores consiliarios y demás individuos que la componen. 1791. Presidente: don Ramón de Posada. Consiliarios: don José Ãngel de Aguirre, don Antonio Barroso, don Antonio Basoco, marqués de Ciria, marqués de San Miguel de Aguayo, don Fausto de Elhuyar, don Bernardo Banavía, don Miguel Constansó. Secretario: don Antonio Piñeiro. Directores: don Gerónimo Antonio Gil, don Ginés de Andrés y Aguirre, don Antonio González Velázquez, don Joaquín Fabregat, don Manuel Tolsá. Tenientes: don José de Alcíbar, don Santiago Sandoval. Académicos de Mérito: don José Damián Ortiz, don José García de Torres, don José Alvarez, don Francisco Guerrero y Torres, don Ignacio Castera, don José Butrón, don José del Mazo Avilés, don Esteban González, don Luis de Martín. Académicos Supernumerarios: don Rafael Gutiérrez, don José María Guerrero, don José María Vázquez, don José Martín Ortiz. Conserje: don Diego Mestre y Pardo.

Ciudades y villas que contribuyen para la subsistencia de la academia: México y sus regidores. Veracruz, Guanajuato, Querćtaro, San Miguel el Grande, Orizaba, Córdoba.

Tribunales: El Real Tribunal de Minería.

628 a. El Real Tribunal del Consulado.

Academias: Madrid, Sevilla, Valencia, Barcelona, Cádiz y sus directores.

629. Representación de los profesores del nobilísimo arte de la pintura, acerca de que se prohíba que los "Tratantes de Pintura" tengan ejercicio. (178-85) 1791 (?) Rúbricas: José de Alcíbar, Francisco Caplera, Andrés López, Rafael Joaquín Gutiérrez, Mariano Vázquez, Juan de Sáenz, Manuel de la Serna, Manuel García.

630. Nómina de los pintores y obradores de pintura que hay en México. 23 de julio de 1791.

1. Calle de las Moras. Don Andrés López, fue uno de los directores de la academia. 
2. Calle de la Servatana. Don Rafael Gutiérrez, fue uno de los directores de la academia.

3. Calle del Relox. Don Mariano Vázquez, fue uno de los directores de la academia.

4. Calle del Relox. Don Juan Sáenz, fue uno de los directores de la academia.

5. Calle de Santa Teresa. Don Francisco Caplera, fue uno de los tenientes de director de la academia.

6. Calle de las Medinas. Don Joaquín Esquivel.

7. Calle de Capuchinas. Don José Alfaro.

8. Calle de la Cadena. Don Francisco Aguirre.

9. Calle de la Merced. Don Francisco Bravo.

10. Calle de las Escalerillas. Don Juan Figueroa.

11. Calle de Santa Teresa. Don Mariano Guerrero.

12. Calle de Santa Teresa. Don José Maín.

13. Calle de Jesús María. Don Manuel Reynoso.

14. Calle del Parque. Don José Polanco.

15. Calle de Santa Isabel. Don Miguel Angel.

16. Calle de Santa Isabel. Don Juan Hurtado.

17. Calle de Lecuona. Don Ignacio Estrada.

18. Calle de la Amargura. Don José Ignacio Barreda.

19. Calle de la Canoa. Don José Balderrama.

20. Calle de San Ramón. Don Valentín Polanco.

21. Calle de Chavarría. Don Francisco Vilchis.

22. Calle de Chavarría. Don José Vallejo.

23. Calle de la Servatana. Don Lucas León.

24. Calle de San Pedro y San Pablo. Don Martín Gaetán.

25. Calle de Tiburcio. Don Onofre.

631. Información sobre las ordenanzas de pintores y doradores de la ciudad de México.

En 1557, siendo virrey don Luis de Velasco, los pintores y doradores pidieron al Ilustre Ayuntamiento se les formasen ordenanzas. Se hicieron y aprobaron pero habiéndose perdido su uso con el transcurso del tiempo, en el año de 1686, hicieron nueva petición al virrey, conde de Paredes, quien aprobó ordenanzas nuevas. El 17 de octubre de 1686.

Extracto de las ordenanzas antiguas (1557).

Extracto de las ordenanzas nuevas (1686). 
632. Testimonio de las ordenanzas del arte de la pintura y dorado. Año de 1791 (legajo con 104 hojas), contiene: petición de Juan López de Pareja, en nombre de todos los pintores y doradores (f.l).

Ordenanzas antiguas (1557 f. 4 vuelta).

Confirmación. 4 agosto 1557. Luis de Velasco (f. 14 vuelta).

Pregón. 9 agosto 1557 (f. 15 vuelta).

Nuevas ordenanzas. 7 diciembre 1681 (f. 16 vuelta).

Respuesta del fiscal. 30 agosto 1686 (f. 22 v.).

Parecer. 17 octubre 1686 (f. 23 vuelta).

ler. Pregón. 28 abril 1687 (f. 26).

$2^{\circ}$ Pregón. 28 abril 1687 (f. 26 vuelta).

3er. Pregón. 28 abril 1687 (f. 28).

Auto. Certificación de los pregones (f. 28 vta.).

Certificación del pregón en Toluca. 18 de abril 1698 (f. 29).

632 a. Petición. Antonio de Salcedo, español, vecino de Xochimilco (f. 29 vuelta).

Presentación de las ordenanzas en el pueblo de Capulac (f. 30 vuelta).

Auto para que se pregonen (f. 30 vuelta).

Pregón en Santiago Tianguistengo. 23 abril 1698 (f. 31 ).

Autos. Certificación de pregones y juramentos de guardar la ordenanza.

Petición. Sobre que los ensambladores no tomen encargos de pintura o dorado (f. 35).

Decreto. 6 de julio 1689 (en relación con lo anterior) (f. 35 vuelta). Auto 5 de julio 1689. Sobre la observancia de las ordenanzas (f. 36). Petición. Francisco de Axpec, en nombre de los veedores del arte de la pintura y dorado, en los autos que siguen con Pedro Maldonado, maestro ensamblador sobre la ejecución de las ordenanzas (f. 48 ).

632 b. Decreto 21 abril 1960 (sobre lo anterior) (f. 48 vuelta). Petición. Francisco Axpec, etcétera en los autos sobre la ejecución de sus ordenanzas (f. 49).

Decreto. 11 agosto 1689 (sobre lo anterior) (f. 49 vuelta).

Petición. Francisco de Axpec, etcétera. Pedro Maldonado continúa en sus fraudes, consintiendo con Gerónimo Marín, maestro dorador, en clorar un retablo del colegio de San Ángel, parte de él se está clorando en casa de dicho Pedro Maldonado (f. 49 vuelta). Decreto. 30 abril 1690 (sobre lo anterior) (f. 51).

Decreto. 30 abril 1690 (sobre fraudes) (f. 53).

Depósito. Embargo de Andrés de Roa (f. 55 vueita). 
632 c. Certificación de Nicolás López y su hijo José tienen obrador público sin ser examinados (f. 60 vuelta).

Embargo (f. 62).

Obrador de Diego Francisco (indio). Ejerce sin ser maestro (f. 62 vuelta).

Embargo (f. 63).

Casa de Nicolás de Torres (f. 63 vuelta). Ejerce sin ser maestro.

Embargo (f. 64).

Andrés de Mendoza. Ejerce sin ser maestro (f. 64 vuelta).

Embargo (f. 64 vuelta).

Auto para que se lleven a la ciudad de México a Diego Francisco y a sus oficiales que se hallan en la cárcel de Xochimilco (f. 68 vuelta).

632 d. Notoriedad al teniente general (f. 69) 1695.

Disposición del virrey marqués de Valero para que le nombren alcalde y veedores (f. 77) 10 de febrero 1717.

Información del alcalde de veedores sobre la casa de Salvador de Ocampo (f. 82 vuelta).

Información del alcalde y veedores sobre la casa de Juan Marcelo Audelo, indio entallador (f. 84 vuelta).

Nota sobre que no se permita se dore en casa de Juan de Rojas. 28 de febrero 1717 (f. 86 vuelta).

Nota sobre que no se permita se dore en casa de Lucas Prieto, indio. Nota sobre que Juan de Rojas no permita se dore en su casa. Marzo 1717 (f. 87 vuelta).

Oficio al virrey sobre que se notifique nuevamente a los que han quebrantado las ordenanzas, por el largo tiempo que había pasado sin haber veedores. Abril 26 de 1717. Don Miguel Díez de la Mora (f. 89 vuelta).

632 e. Petición para que no sean multados los infractores con fecha anterior a la elección de veedores. Abril 28, 1717 (f. 91).

Decreto. 31 mayo 1717 (f. 32 vuelta).

Petición de Juan de Rojas y Salvador de Ocampo para que se les dé 6 meses de permiso para acabar y entregar las obras que ya tienen comprometidas, sin que los molesten los veedores (f. 93).

Decreto. 2 marzo 1717 (informe al corregidor) (f. 95).

Contestación que necesita saber quiénes son los multados y por quién.

4 de marzo 1717. Don Miguel Díaz de Ta Mora (f. 95).

Informe sobre el asunto de Juan de Rojas y Salvador Maldonado. 12 marzo 1717 (f. 95 vuelta).

$632 \mathrm{f}$. Decreto 13 de abril 1717 (f. 96 vueita) que se lleve el memorial al corregidor. 
Notificación a Jacinto Nadal, alcalde de dorador (f. 97) 16 de abril 1717.

Información del alcalde y veedores sobre los multados 12 de junio 1717 (f. 97).

Decreto 30 de junio 1717. Como parece al señor Asesor (f. 99).

Notificación a Juan de Rojas. $1^{\mathrm{O}}$ junio 1717 (f. 99 vuelta).

Notificación a Salvador de Ocampo. Misma fecha ídem.

Notificación a Juan Marcelo. Misma fecha (f. 100).

Petición del alcalde y veedores para que se pasen los autos pendientes al corregidor (f. 100 vuelta).

Decreto. Como lo piden 3 julio 1717 (f. 101).

Petición del alcalde y veedores para que, según lo acordado, se pregonen las ordenanzas para que no se alegue desconociniento.

632 g. 3 julio 1717 (f. 101 ).

Orden del corregidor para que se pregonen las ordenanzas.

8 julio 1717 (f. 102).

$1^{\mathbf{0}}$ pregón 24 julio 1717 (f. 102 ).

$2^{\circ}$ pregón 24 julio 1717 (f. 102 vuelta).

$33^{0}$ pregón 24 julio 1717 (f. 103).

Información de Francisco de Landa en nombre del alcalde Jacinto Nadal y Zubet sobre que desde el año 1689 se siguieron los autos sobre la observancia de las ordenanzas. Se manifiesta las penas de los transgresores y que se les cobren multas (f. 103).

Decreto 21 agosto 1717. Guárdense y cúmplase (f. 104).

Notificaciones a Juan de Rojas y Salvador de Ocampo (f. 104 vuelta).

Certificación del escribano Real Mariano de Zepeda sobre todo lo contenido en el testimonio y su concordancia con los originales. México 9 de agosto de 1791 .

$632 \mathrm{~h}$. Nota: Este expediente debe estudiarse y publicarse en parte, sobre todo las ordenanzas mismas. Justino Fernández. 10 de enero 1943.

633. Cuenta de los derechos devengados según arancel, del testimonio de ordenanzas del arte de la pintura y dorado. De lo escrito en 104 fojas. Agosto 17 de 1791. Mariano de Zepeda.

634. Solicitud de don Bernardo y don Gabriel Gil sobre que se les conceda el grado de Académicos de Mérito en el ramo del grabado en hueco. Enero 1791.

Certificado de don Gerónimo Antonio Gil. 19 enero 1791 (en la solicitud dicen que son hijos de don Gerónimo y que pasaron a Nueva España en 1777). 
635. Solicitud de José Loreto Villanueva, sobre que se le conceda el grado de Académico de Mérito, en el ramo de arquitectura. Julio 1791.

Certificado de don Antonio González Velázquez. 3 agosto 1791. Acuerdo de la junta. 9 septiembre 1791.

636. Superior aprobación de los Académicos de Mérito, don Esteban González, don Luis Martín, don José María Vázquez y don José María Guerrero. Contiene las solicitudes individuales y la aprobación del virrey, conde de Revillagigedo. 27 octubre 1791.

637. Oficio de S. E. (Revillagigedo) acompañando la instancia de don Antonio Santa María Incháurregui, sobre que se le cree Académico de Mérito en el ramo de arquitectura, o se le nombre maestro mayor en la ciudad de Puebla, con el informe de la junta superior. 1791.

638. Nota de los libros que componen la Biblioteca de la Real Academia de San Carlos. 1791.

639. Nota de los muebles que llevó don José Marrugat del Colegio de San Andrés. 1791.

640. Nota sobre medallas y monedas.

641. Recibo por $\$ 10$ firmado José María Zamarripa. 1788.

642. Recibo por $\$ 175$ por sueldos, firmado Tomás de Echegaray. 1787.

643. Notas de los libros, estatuas y demás útiles que en dos remisiones vinieron de España para el uso en la academia. 1791.

644. Instancia de Cristóbal Nápoles sobre que se le conceda licencia para dirigir la construcción de las bóvedas de una iglesia en el pueblo de Tenancingo.

Certificaciones de don Francisco Antonio Guerrero y Torres, Br. José Mateo Valenzuela y don Ramón de Posada. 1791.

645. Solicitud del grabador don José Joaquín Fabregat sobre que se habilite de buriles y demás cosas necesarias a su discípulo José Huerta. 16 de marzo de 1791.

646. Instancia de don Francisco Caplera sobre que se le confiera la plaza de segundo director de pintura, vacante por la dimensión de don Cosme de Acuña, con la Real Orden en que se le concede permiso. a éste para su regreso a España.

Orden del virrey (Revillagigedo) 31 marzo 1790.

Copia de un oficio de la academia al virrey en que se dice no se puede nombrar sucesor de Acuña hasta no saber si se va. Junio 3 1790.

Solicitud de Francisco Caplera (dice que Gil lo nombró en 4 de 
noviembre 1781 director mientras venían maestros de España. $1 \delta$ marzo 1791.

Oficio del virrey (Revillagigedo) para que se tenga presente la solicitud 23 de marzo de 1791.

646 a. Oficio en que la junta dice no estar enterada del asunto, pide al virrey le pase la Real Orden y demás. 4 abril 1791.

Oficio del virrey pasando el expediente. 8 abril 1791.

Acuerdo de la junta, enterada del permiso concedido a Acuĩa para regresar a España; opina que no hay pintores capaces para reemplazarlo pues, ni Caplera, ni Alcíbar, ni Rafael Gutiérrez reúnen las condiciones necesarias; piden que se mande nuevo director, de España. $1^{9}$ mayo de 1791.

647. Representación del director de matemáticas don Diego Guadalajara sobre la indispensable necesidad de nombrar decuriones o substitutos que le auxilien. 29 agosto 1791. Proporciona una lista de los sujetos.

648. Renuncia que hizo don Francisco Caplera del empleo de teniente director de pintura. 22 diciembre 1790 .

Oficio del virrey (Revillagigedo): enterado. 5 de enero de 1791.

Oficio de la academia al virrey, enterada de la renuncia de Caplera y mientras se da aviso a los profesores que fuesen más acreedores al puesto, que lo desempeñen don José María Vázquez y don José María Guerrero. 4 de enero de 1791.

649. Memorial del director de matemáticas sobre que se fijen rotulones participando al público que el curso de aritmética universal deberá empezar el día 16 de mayo. 1791.

650. Representación de la junta de policía sobre los inconvenientes que prepara la colocación de dos cruces de piedra sobre globos de la propia materia, que deben coronar las torres de la Santa Iglesia Metropolitana. Marzo-mayo 1791.

651. Superior Orden de S. E. (Revillagigedo) participando haber prevenido al señor intendente de Veracruz facilite al director de escultura don Manuel Tolsá, los auxilios necesarios para conducir a esta capital los útiles que conduce con destino a la academia. Mayo de 1791 .

652. Oficio a S. E. (Revillagigedo) del presidente de la academia, quedando enterado de la Real Orden respecto a los útiles que vienen a cargo de don Manuel Tolsá. 27 de julio de 1791.

653. Expediente formado para el entero en Cajas Reales de los $\$ 16,794$ suplidos en Veracruz al director de escultura don Manuel Tolsá para la conducción de los cajones de estatuas y demás útiles desde aquel puerto hasta esta ciudad. 1792. 
654. Instancia de los pensionados de escultura sobre que se les dé alguna gratificación por el trabajo que emprendieron en ayudar a montar las estatuas. José López, Juan Fortés, Pedro Patiño Ixtolinque. 1793.

655. Instancia del director de escultura don Manuel Tolsá sobre que se le suplan $\$ 1,000$ para pagar los empeños que contrajo en su viaje. 1791 .

656. Expediente sobre el entero de $\$ 1,000$ en las Cajas Reales: los $\$ 750$ suplidos en Cádiz del caudal de la Real Hacienda al director de escultura don Manuel Tolsá para su transporte y conducción a este rcino: y los $\$ 250$ restantes por los derechos, a razón de peso fuerte por sencillo. 1791.

657. Solicitud de los pensionados en el ramo de escultura, Pedro Patiño, Juan López y Juan de la Cruz, sobre que se les faciliten los útiles necesarios para el ejercicio de su arte. Julio de 1791.

658. Solicitud de los jóvenes don Juan Sánchez y don José Gutiérrez sobre que se les habilite de ropa (presenta lista de la que necesita). 1791 .

659. Cálculo del costo que puede tener la habitación de la galería de estatuas y sala de pintura, formado por el director don Antonio González Velázquez. Octubre de 1791.

660. Expediente formado sobre el nombramiento de profesores, que valúen las obras de pintura, escultura y arquitectura. 1791. Pintura: director don Ginés de Aguirre, don Cosme de Acuña, don José Alcíbar, don Francisco Caplera, don Rafael Gutiérrez. Escultura: don Santiago Sandoval y don Ignacio Sandoval. Arquitectura: director don Antonio González Velázquez, don José Damián Ortiz de Castro, don Ignacio Castera, don Francisco Guerrero y Torres, don José del Razo, don Esteban González. Grabado en hueco: director general don Gerónimo Antonio Gil. Grabado en lámina: director don José Joaquín Fabregat. Enero 1791.

661. Solicitud de don Diego de Guadalajara y Tello para que se fije en la pared del frontis de la Real Academia una lápida de tecali con el siguiente sagrado verso:

Señor, y Dios mío

Vuestro nombre sacrosanto sea en todo el Orbe bendito, y todos con dulce canto Digan levantando el grito: ¡Oh Dios Santo, Santo, Santo! 1791. 
662. Solicitud del pensionado don José María Montes de Oca sobre que se le permita hacer su oposición en las ramas de escultura o dibujo.

663. Solicitud del Académico de Mérito don Joaquín de Heredia pidiendo que se pase aviso a la junta municipal de esta ciudad, de su nombramiento. 1791 .

664. Instancia de don Pedro Manuel Tapiz sobre que se dé certificación de su aplicación y progreso en la matemática. 1791.

665. Instancia de don José María Arrospide acerca de que se le restituya la pensión en el ramo de arquitectura. Con certificado de don Antonio González Velázquez. 1791.

666. Expediente sobre los planos formados por el arquitecto don Francisco Antonio Guerrero y Torres para el reedificio de unas casas en la calle de Balvanera. 1791.

667. Expediente formado para la aprobación de los planos de una casa propia del Convento de Religiosas de Regina, en la calle de la Cruz Verde. 1791.

668. Expediente sobre nombramiento de maestros que deben enseñar el dibujo de figura y delineaciones en el Colegio Metálico del Real Tribunal de Minería. 1791.

Se nombró a don Esteban González y a don Bernardo Gil para maestros de dibujo y arquitectura en el seminario de metalurgia.

669. Solicitud de don Miguel Villerías, sobre que se le aumente el honorario que goza para la recaudación de los arrendamientos del solar de Milpantongo. 1791.

670. Solicitud del pensionado don José María Vázquez sobre que se le dé alguna gratificación por los retratos que pintó de los excelentísimos señores don Manuel Antonio Flórez y don Matías de Gálvez. 1791.

671. Solicitud de don Pedro Patiño Ixtolinque sobre que se le dé certificación de ser pensionado en el ramo de escultura. 1791.

672. Solicitud de don Ginés de Aguirre sobre que se le permita tomar a su cargo la obra de pintar al fresco la bóveda del bautisterio del Sagrario de la Santa Iglesia Metropolitana. Marzo 28 de 1791.

"que habiéndole comisionado para pintar a el fresco la bóveda del bautisterio de El Sagrario, obra que puede serles útiles a los pensionados de esta Academia, pues hasta la presente no se ha ejecutado semejante método en América; porque sin embargo de haberse hecho algo, no es el verdadero fresco, sujeto a las buenas y precisas máximas que semejante pintura requiere; ni tampoco los discípulos han logrado ver cómo se ejecuta..." 28 de marzo de 1791. Ginés de Andrés y de Aguirre. 
673. Aviso al señor alcalde decano de la Real Sala del Crimen don Luis de Chávez y Mendoza, acerca de que uno de los porteros de la Real Academia dio dos heridas a un pensionado. 19 de mayo de 1791.

674. Carta del juez don Antonio Montero y Velarde a don Ramón de Posada, acerca de que se nombren dos o tres sujetos de la academia condiscípulos del pintor José Antonio Polanco, para no demorar la causa criminal que está formando al susodicho. 9 de marzo de 1791.

675. Oficio del alcalde don Luis de Chávez y Mendoza al señor don Ramón Posada, expresando tener conocimiento de las heridas causadas por un portero de la Academia a uno de los pensionados $y$ que ya dispuso la traslación del reo a la cárcel de la corte. 20 de mayo de 1791.

676. Oficio al excelentísimo señor virrey conde de Revillagigedo a fin cle que se sirva mandar se circule orden a todos los señores intendentes para que dispongan que los maestros de obras titulados ocurran a examinarse en el término que se expresa. 24 de septiembre de 1794.

677. Carta de don Ramón de Posada a don Antonio María Fernández dándole las gracias por el retrato del serenísimo señor Príncipe de Asturias que ha regalado e informándole que le remite una copia del mismo por el conducto del cadete don Andrés Amat de Tortosa que pasa a España en compañía del conde de Casa Flores. 7 de julio de 1791 .

678. Oficio del señor presidente sobre la utilidad que resultara de que el pensionado en ramo de arquitectura don José Gutiérrez acompañe al teniente de guardias españolas don Antonio Pineda en el viaje que está por hacer al Real de Guanajuato y otras partes. 21 de agosto de 1791 (al señor conde de Revillagigedo).

679. Impreso comunicando a la Real Academia la Rcal Orden de 24 de marzo de 1791. La Real Orden se refiere a que a don Antonio Porlier se le ha concedido Título de Castilla, para él y sus hijos y sucesores, con la denominación de marqués de Baxamar (el conde de Revillagigedo, rúbrica). 6 de julio de 1791.

680. Oficio cnviando a su excelencia, el conde de Revillagigedo el estado de entrada y salida de caudales de la Real Academia 11 de febrero de 1791.

681. Contestación del conde de Revillagigedo a la junta de gobierno de la Real Academia, diciendo que queda enterado por el estado enviado de la entrada y salida de caudales. 12 de febrero de 1791. 
682 al 691 cancelados.

692. Oficio al señor conde de Revillagigedo a la Real Academia, ordenando que los oficios que se le envíen vayan dirigidos a la oficina a que el asunto corresponda. 18 de julio de 1791.

693. Oficio tomando nota del anterior (692). 27 de julio de 1791.

694. Oficio del señor conde de Revillagigedo acerca de que la junta superior de gobierno informe sobre la actividad, aplicación y conducta de don Antonio Piñeiro, en el empleo que ha servido a la academia desde el año de $1785.1^{\circ}$ enero 1794.

695. Oficio del señor conde de Revillagigedo acerca de la forma de tramitación de oficios (véanse números 692 y 693). 22 de julio de 1791.

696. Oficio del señor conde de Revillagigedo acerca de que han sido de su aprobación los nombramientos de don Esteban González y don Bernardo Gil para maestros que enseñen en el Colegio Metálico del Real Tribunal de Minería, la delineación de planos de edificios, máquinas, diseños geográficos, hornos, vistas de campo y el dibujo de figura. 26 de diciembre de 1791.

697. Oficio acerca de cómo deben cubrirse los gastos originados por el transporte de don Manuel Tolsá, una sobrina y un criado, así como de los cajones y barriles con útiles para la Real Academia, que llegaron al puerto de Veracruz en la fragata de guerra nombrada Santa Paula, al mando del tenierie de navío, don Miguel Cuadrado, que partió del puerto de Cádiz. 14 de mayo de 1791.

698. Solicitud de pensión en el ramo de arquitectura, por don José María Pulgar. 27 de marzo de 1791. Certificación de don Antonio González Velázquez.

699. Renuncia que hizo don José María Pulgar de la pensión que obtenía. 31 de enero de 1796 (véase 698).

700. Solicitud de pensión en el ramo de arquitectura de don Manuel Bustamante. Marzo 1791. Certificaciones de don Antonio González Velázquez.

701. Expediente sobre los planos formados por el arquitecto don Francisco Guerrero y Torres para la fábrica de una casa en la calle de Mesones. Abril 1791.

702. Expediente sobre la aprobación de los planos formados por el arquitecto don José Joaquín García Torres para la construcción de una casa en la calle de Medinas. Diciembre 1791.

703. Oficio del señor conde de Revillagigedo a don Ramón de Posada comunicándole lo que le dice el señor marqués de Bajamar en la Real Orden de 18 de abril de 1791. 
La Real Orden se refiere a los 76 cajones con modelos y otros útiles para la Real Academia que se embarcaron en la fragata de guerra Santa Paula que salió de Cádiz para La Habana el 20 de febrero; recomienda se conduzcan hasta la capital, a cargo de don $\mathrm{Ma}$ nuel Tolsá, en el mejor modo y forma para su conservación. 22 de juilio de 1791.

704. Oficio del excelentísimo señor virrey insertando la Real Orden de 23 de julio de 1791 en que se concede al director don Manuel Tolsá el goce de su respectivo sueldo desde el día 12 de septiembre de 1790. 12 de noviembre de 1791.

705. Oficio del señor conde de Revillagigedo al presidente de la Real Academia, comunicándole lo que le dice don Pedro de Lerena, acerca de que los 76 cajones con modelos y demás útiles para la academia, van libres de todos derechos. 28 de enero 1791.

706. Oficio del señor conde de Revillagigedo al presidente de la Real Academia comunicándole de lo que le dice don Antonio Porlier, acerca de que el rey se ha servido nombrar a don Manuel Tolsá para el empleo de director de escultura de la Real Academia vacante por la muerte de don José Arias, cuyas hermanas doña Francisca y doña Paula percibirán todavía $\$ 200.00$ de pensión, quedando $\$ 1,800$ a favor del nuevo director. 28 de enero de 1791 .

707. Oficio del señor conde de Revillagigedo a la junta de gobierno comunicándole lo que le dice don Antonio Porlier, acerca de que los modelos y demás útiles que contienen 76 cajones, se han confiado para su conducción hasta la capital a don Manuel Tolsá. 28 de enero de 1791.

708. Copia de un oficio acerca de los fondos adelantados en Cádiz para la conducción de los 76 cajones con modelos y demás útiles para la academia, confiados a don Manuel Tolsá. 14 de febrero de 1791.

709. Orden Superior para que el secretario de la academia ocurra a los ministros de la tesorería general a recibir los tres cajones con instrumentos, libros, estampas y dibujos venidos de España. 19 de febrero de 1791.

710. Orden de S. E. para que se entregue a don Tomás Suría la obra de pintura de don Antonio Palomino y recibo que dio de ella con obligación de volverla, concluyendo su viaje. 25 de enero de 1791 (el viaje a que se refiere es el que hizo con Malaspina a Alaska en 1791. Consúltese “Tomás de Suría y su viaje con Malaspina 1791" por Justino Fernández. Edit. Porrúa Hnos. y Cía. México 1939).

711. Oficio de S. E. acompañando la solicitud de don Gregorio Pérez para el establecimiento de una escuela de dibujo en Guadalajara 
y el informe de la junta superior de gobierno. Marzo-abril de 1791.

712. Orden Superior para que se faciliten al capitán de navío don Juan de la Bodega, 25 pliegos de papel marca para los importantes asuntos del servicio. 9 de noviembre de 1791 .

713. Expediente sobre fábricas de colegios de niñas. 1791-1800. Contiene: a) Expediente formado sobre la aprobación del plano para el colegio de niñas de la Villa de Córdoba 1791. El plano fue formado por don Manıel Ortiz y don Vicente Suárez. El dictamen de don Antonio González Velázquez dice: “.... considero preciso se mande formar nuevo y más juicioso plano." 27 de junio de 1791. Otro dictamen de don Antonio González Velázqucz diciendo: “... El diseño que se me ha remitido... están mal formados que ni remotamente se puede hacer juicio de él." 26 de octubre de 1791. b) Año de 1800: instancia de don Diego Antonio Salbago, cura de Irapuato sobre la aprobación de los planos que presentó; levantados por el Académico de Mérito don Esteban González, para la construcción de un colegio de niñas en aquel pueblo, con el informe que hizo en el asunto el director de arquitectura don Antonio Velázquez. El dictamen de don Antonio González Velázquez dice que encuentra los planos "bien distribuidos e ingeniosamente aprovechado el irregular terreno". 5 de marzo de 1800.

713 a.c) Expediente sobre la aprobación de los planos formados para la construcción de un colegio de niñas con el título de Nuestra Señora de los Dolores. 1791 (en la ciudad de México). Solicitud del autor de los planos don José Joaquín García de Torres, para la aprobación de la nueva fábrica que va a fundar el reverendísimo padre prepósito don Manuel Bolea, del oratorio de San Felipe Neri. Agosto de 1791.

713 b. "Breve descripción en substancia de la mente y consideraciones bajo de las cuales se lian formado y levantado los planos... (interesante informe) fechado en 9 de agosto de 1791 y firmado don José Joaquín García de Torres.

Dictamen de don Antonio González Vclázquez indicando que “...en cuanto a las plantas nada tengo que advertir... pero las fachadas exteriores deberán reformarse. .." Se deberán presentar diseños reformados y juntamente de la elevación interior de la capilla, pues es pieza de consideración y de ella nada hemos visto. 14 de septiembre de 1791.

714. Expediente sobre fábricas de iglesias. 1791.

Contiene: Expediente formado sobre la aprobación de los planos 
de la iglesia del Plan del Río. 1791 (lugar de tránsito entre Jalapa y Veracruz).

Dictamen de don Antonio González Velázquez. 31 de mayo de 1791.

Carta del virrey Iturrigaray al marqués de San Román, remitiéndole el expediente relativo a la reedificación de la iglesia parroquial de Sultepec. 9 de junio de 1808.

Oficio del virrey a la Real Academia para que dictamine sobre la fábrica de la iglesia parroquial del pueblo de Coyoacán. 16 de julio de 1798.

Expediente sobre los planos presentados por el ilustrísimo señor obispo del Nuevo Reino de León para la fábrica de aquella iglesia catedral. 1792.

Dictamen de don Antonio González Velázquez, diciendo que sólo se ha presentado la planta...

714 a. "que es un breve trasunto de la Catedral de México, mal copiado y peor proporcionado", y que por lo tanto nada puede decir. 15 octubre 1792.

Expediente sobre la aprobación de los planos formados para la construcción de la iglesia en Tepantitlan. 1792.

Dictamen de don Antonio González Velázquez diciendo: "que es necesario hacer planos nuevos". 27 de octubre de 1792 .

Expediente sobre la aprobación de los planos formados para la Coristrucción de las Casas Reales y cárcel municipal en San Luis Potosí. 1796.

Dictamen de don Antonio González Velázquez. 26 de agosto de 1796.

Oficio del señor regente de esta Real Audiencia don Baltasar Ladrón de Guevara sobre que se destine un sujeto de esta academia para que pase a reconocer la iglesia parroquial del pueblo de Xiquipilco, y nombramiento que para el efecto se hizo del académico de Mérito don José Gutiérrez. 1797.

714 b. Oficio de don Baltasar Ladrón de Guevara diciendo que: "Habiéndose quemado la Iglesia Parroquial del pueblo de Xiquipilco del Partido de Ixtlahuaca se está tratando del reedificio." 17 de mayo de 1797.

Oficio de S. E. sobre que el director Velázquez concluya las diligencias que se le encargaron, relativas al reedificio de la iglesia de Xiquipilco, con el informe que hizo éste y la contestación del señor presidente acompañándolo. 1799.

Memorial del director de escultura don Manuel Tolsá presentan- 
do los diseños que formó para la construcción de un tabernáculo en la Santa Iglesia Catedral de Puebla, a fin de que se examinen y reconozcan por la academia. 6 de noviembre de 1798 .

714 c. Oficio del señor regente don Baltasar Ladrón de Guevara, como comisionado de S. E. acompañando el expediente girado por el cura de Telopoapan, sobre que se le conceda licencia para la construcción de una capilla en la hacienda de Tesilacatlán, con la contestación del señor presidente acompañándole copia certificada del informe que hizo en el asunto el director de arquitectura don Antonio González Velázquez. 1798.

Expediente sobre examen y aprobación de los planos formados para la fábrica de la iglesia parroquial de la Purificación, provincia de Nueva Galicia, formados por el maestro don Luis González. 1799-1800.

Expediente sobre el reedificio de la iglesia parroquial de Santa Catalina Xochatipan, Partido de Ayahualica. 1799.

Gaveta 6. 1792 (números del 715 al 763).

715. Hoja impresa. Programa de asuntos para aspirar a premios en las diversas materias. 15 de septiembre. 1792. Firnada: Antonio Piñeiro.

716. Instancia del discípulo de matemáticas don Luis de Tola y Salcedo sobre que se le dé una pensión. Contestación de don Diego de Guadalajara, director de matemáticas, apoyando la solicitud de su discípulo. Julio 31 de 1792.

717. Sobre los medios de habilitar con grabadores la expedición botánica a cargo de don Martín Seré. 12 de septiembre 1792.

Copia del oficio de la junta remitido al señor conde de Revillagigedo. Opinión del director de la Real Academia don Jerónimo Antonio Gil y de don José Joaquín Fabregat. Dice Gil en su informe que tomará a su cargo a don Tomás Suría, "de cuya expresión se deduce que no tiene aún la aptitud necesaria para trabajar por si".

718. Expediente sobre defectos advertidos en la construcción de la parroquia de San José de esta capital y medios de repararlos. Años de: 1792-1796-1797-1798 y 1799.

Informe de don Antonio Velázquez sobre el reconocimiento que hizo a la iglesia parroquial de San José, del macstro Francisco Torres. 27 de octubre 1792. 
Petición del cura don Diego Alvarez, para que el director de la obra don José Mazo "acorte el vuelo de las cornisas". Oficio de don José del Mazo y Avilés a don Antonio Piñeiro. 2 de agosto de 1797.

Informe de don Antonio Velázquez a la junta. 31 agosto de 1797. Oficio de don José del Mazo, quien dice que el informe de don Antonio Velázquez obedece a que "hace algún tiempo... no perdona medio alguno de cuanto le dicta su encono para perjudicarme".

Acuerdo: se comisiona al consiliario don Ciriaco Carvajal para que presencie el reconocimiento que hará a la parroquia de San José, el director de escultura don Manuel Tolsá. Noviembre de 1797.

Informe de don Antonio Velázquez. Noviembre de 1797.

Informe y defensa de don José del Mazo en que hace constar que él tomó la obra comenzada por don Francisco Guerrero y Torres. Informe del cura párroco bachiller don Diego Alvarez.

Informe de don Manuel Tolsá, declarando que la obra no está "ni con mucho conforme a los planos". 4 de febrero de 1798.

La junta comisionó a don Manuel Antonio Flores. 25 de agosto de 1798.

Oficio de remisión a del Mazo, de la resolución de la junta. 11 de junio de 1798.

Carta de don José del Mazo acusando recibo. 26 de junio de 1798. Acuerdo de la junta, dirigido al bachiller don Diego Alvarez. 22 de marzo de 1799.

Acuerdo de la junta, dirigido a don José del Mazo. 22 de marzo de 1799.

719. Solicitud del pensionado José María Guerrero sobre que se le paguen los retratos que pintó de los excelentísimos señores conde de Gálvez, conde de Revillagigedo y del ilustrísimo señor arzobispo. 31 de enero de 1792.

720. Solicitud del pensionado de escultura don Ignacio Sandoval sobre que se le exima de la asistencia de día a la academia.

Informe de don Manuel Tolsá, sobre lo irregular de la petición y oponiéndose. 31 de enero de 1792.

721. Solicitud del director de escultura don Manuel Tolsá sobre que se agregue a su taller la accesoria inmediata a la casa de academia (con motivo de habérsele cncargado unas estatuas colosales para nuestra Santa Iglesia Catedral). 30 de octubre de 1792.

722. Solicitud de don Bernardo Gil y don Esteban González, directores de dibujo y delineaciones del Colegio Metálico, sobre que se lcs despachen sus respectivos títulos. 28 de febrero de 1792. 
723. Solicitud del director de escultura don Manuel Tolsá, sobre que se le consulte a $S$. $M$. para que se le exima del gravamen de los 200 pesos que le desfalcan de sus sueldos, en virtud de la Real Orden para alimentos de las dos hermanas de su antecesor. 1792. El antecesor fue don José Arias.

Certificado de matrimonio de una hermana de Arias.

Certificado sobre Juan Antonio González Montáñez.

Certificado sobre Juan Antonio González Montáñez.

Solicitud de don Manuel Tolsá. 1791.

Oficio de la junta al virrey Revillagigedo. 29 de noviembre de 1793.

Oficio de Revillagigedo, informando que hará presente al rey la solicitud. 30 de noviembre de 1793 .

Oficio del virrey Branciforte a la junta comunicando la decisión del rey sobre que la carga de los 200 pesos se descuente en adelante, de los más nuevos directores, según se les vaya nombrando. 29 de febrero de 1795.

Copia del nombramiento de Académico de Honor (Manuel Tolsá) por decreto de 27 de julio de 1793.

724. Instancia del pensionado don José María Vázquez sobre que se le pague el retrato que pintó del excelentísimo e ilustrísimo señor arzobispo don Alonso Núñez de Haro. 28 de marzo de 1792.

725. Instancia del Académico de Mérito don José Damián Ortiz sobre que la junta de policía no le precise a presentarle los planos, ni darle noticias de las obras que se le encarguen, con arreglo a los estatutos. 20 de octubre de 1792.

Ocurso a la Real junta de policía.

Auto de la junta de policía, diciendo que todos los maestros tienen que dar aviso de las obras que hagan, sean grandes o pequeñas.

Memorial a la Real Academia sobre el portal de la Preciosa Sangre, de don José Damián Ortiz.

Oficio a la junta de don José Damián Ortiz, diciendo que con su concepto para aplicar las ordenanzas "vejando y haziendo odiosa la profesión de la Arquitectura..." 29 de septiembre de 1792.

Auto de la junta sobre el conocimiento que debe tener la junta de policía de si se cumplen o no las providencias y reglas. 23 de octubre de 1792.

Oficio de don José Damián Ortiz protestando porque le suspendieron una obra.

726. Expediente sobre la instancia de don José Oriñuela, relativa a que se le conceda permiso para establecer en Querétaro una escuela de matemáticas. 1792. 
Oficio de remisión del expediente de Revillagigedo.

Pareceres de don Diego Guadalajara y don Antonio Velázquez. 28 de noviembre de 1792 .

Oficio de la junta al virrey Revillagigedo con copia de los anteriores pareceres. $1^{\circ}$ de diciembre de 1792 .

1793. Don José Oriñuela sobre que se le permita establecer en Querétaro una academia de principios de matemáticas.

Oficio de Revillagigedo remitiendo el expediente a la junta. 25 de junio de 1793.

Contestación de la junta. 30 de junio de 1793.

Certificación del examen hecho a don José de Oriñuela por don Diego de Guadalajara (...Lo juzgo capaz...) 15 de julio de 1793. Oficio de Revillagigedo a la junta sobre que se extienda a don José de Oriñuela el título de Académico correspondiente. 14 de agosto de 1793 .

Acuse de recibo del expediente. 24 de noviembre de 1792.

727. Representación del director de matemáticas don Diego Guadalajara sobre el método con que se propone enseñar el curso de geometría. 1792.

728. Borrador del reglamento que hizo el conserje sobre las obligaciones del portero. 1792.

729. Solicitud de José Mariano Guerrero, Manuel José de Aguirre, mozos de la academia sobre aumento de sueldos. 1792.

730. Edicto. Programa ( 2 ejemplares impresos) para el certamen de premios. 15 de septiembre de 1792.

Original y autorización para imprimirse.

Oficio en que se dice haber distribuido los premios generales. 13 de diciembre de 1793.

Oficios de algunos señores intendentes dando cuenta que han recibido y fijado en las paredes los edictos que se les enviaron. Valladolid. Oaxaca. Durango. Zacatecas.

731. Solicitud del director de matemáticas don Diego Guadalajara pidiendo se active la aprobación de su nombramiento y del aumento de sueldo que se le hizo, pagándosele entre tanto al respecto, de otra asignación. 1792.

Resuelto en junta de 30 de abril de 1792.

732. Instancia de los pensionados por el ramo de escultura sobre que se les habilite de los instrumentos necesarios para el ejercicio de su arte. Julio 31 de 1792. Manuel López, Ignacio Sandoval, Juan Fortés, Pedro Patiño (resuelto en junta de 22 de agosto de 1792). 
733. Representación del director de matemáticas don Diego Guadalajara sobre que se habilite de varios útiles la sala de su cargo. 1792.

734. Solicitud de don Manuel Muñoz y don Mariano Granados sobre que se les expidan títulos de agrimensores. 1792.

735. Sobre los maestros de albañilería que existen en la provincia de Veracruz sin títulos acordó la junta de gobierno que en atención a la falta de arquitectos se disimule por ahora previniendo al señor intendente que cuando se ofrezca construir algún edificio de consideración ocurra a esta academia por los planos. 1792.

736. Solicitud de don Juan Crouset, sobre que se le examine en el arte de arquitectura. 1792.

737. Solicitud del maestro de obras Pedro Rodríguez, vecino del pueblo de Nuestra Señora de San Juan de los Lagos, sobre que se le examine y conceda licencia para dirigir y ejecutar fábricas. 1792.

738. Sobre fábricas de capillas, conventos y colegios. 1792. Informes de don Antonio Velázquez, don Ignacio Castera y del teniente coronel don Miguel Constansó, sobre la fábrica del Oratorio de San Felipe Neri en Querétaro. 1792. Sobre fundación de un convento de religiosos franciscanos en el pueblo de Puruándiro. 1796.

Sobre la aprobación de los planos de una iglesia en el colegio de San José de Carmelitas del Tercer Orden, de Querétaro. 17971798.

Sobre aprobación de los planos formados por el director de escultura y Ácadémico de Mérito de Arquitectura don Manuel Tolsá para la construcción de un convento de religiosas Teresas en Querétaro. 1797.

Informe del director de arquitectura don Antonio Velázquez sobre los planos formados para la construcción de un colegio de propaganda fide en Monterrey. 1796.

Sobre establecimiento de misiones en la Nueva Vizcaya (Casuxichi y Gucaybo). 1797.

Oficio de su excelencia acompañando el expediente formado sobre construcción de un colegio de misioneros en la Villa de Orizaba, para que don Antonio Velázquez, que hizo el plano, extienda también el cálculo de su costo; calificándose todo por uno de los Académicos de Mérito. Así se hizo y se devolvió todo a S.E. 1799.

739. Sobre la obra de la casa de dirección y fábrica de tabaco de esta capital. 1792.

740. Expediente sobre la aprobación de los planos de una casa en la calle de Tacuba, presentados por el arquitecto don José Joaquín García de Torres. 1792. 
741. Expediente sobre la aprobación de los planos formados por don José Buitrón para la fábrica de una casa en el callejón del Torno de Regina. 1792.

741 bis. Sobre permiso para vender al Tribunal de Minería el solar que la academia posee, llamado Nilpantongo. 1792 (solar donde hoy día se encuentra el edificio de la Escuela de Minería).

742. Superior orden para que se facilite por su justo precio al teniente coronel don Miguel Constansó el color carmín que necesita. 1792.

743. Superior orden para que se examine el plan y reglas bajo que piensa establecer, don José María Alfaro, en Jalapa, una escuela patriótica. 1792.

743 bis. Superior orden para que el pensionado don Mariano Bustainante pase a la caja de don Miguel Constansó a ayudar a sacar varios planos. 1792 .

744. Sobre seis cajones de estampas, pinturas y demás que condujo el navío San Pedro de Alcántara, para el uso de la academia. 1792 (listas de lo contenido).

745. Sobre que se encarguen a España lienzos de pinturas de los mejores profesores y los estuches de matemáticas. 1792.

745 bis. Oficio felicitando al excelentísimo señor don Pedro de Acuña por haber sido nombrado secretario de Estado y despacho universal de gracia y justicia, y esperando su protección. 1792.

746. Oficio de don Cosme de Acuña participando haberle nombrado $\mathrm{S}$. M. por director de los pensionados que hayan de pasar a la corte. 1792.

747. Solicitud de examen del arquitecto de Guadalajara, don José de Conique. 1792.

748. Cuenta de lo gastado en la obra de la casa del Amor de Dios (actual Academia) desde 26 de abril de 1791 en que se empezó, lasta el 31 de enero de 1792.

749. Cálculo formado por el director don Antonio González Velázquez para la conclusión de la casa del Amor de Dios (actual Academia). 1792.

750. Repartimiento de medallas formado de orden de la junta superior de gobierno, con las adiciones hechas en él por el excelentísimo señor virrey viceprotector conde de Revillagigedo. 1792.

751. Orden del virrey, conde de Revillagigedo para que se le envíe otra medalla, de las anteriores (750). 1792.

752. Remisión de medallas de la Real Academia. 1792 (copia de un oficio). 
753. Acuse de recibo de tres medallas (750) Antonio Valdez. 1792.

754. Acuse de recibo de medallas (750). 1792.

755. Acuse de recibo de medallas (750). 1792.

756. Acuse de recibo de medallas (750). 1792.

757. Acuse de recibo de medallas (750). 1792.

759. Varios acuses de recibo de medallas (750). 1792.

760. Minutas de envío de medallas. 1792.

761. Minutas de las cartas con que se acompañaron las medallas. 1792.

762. Expediente sobre que en la capilla de Nuestra Señora del Carmen se observen los planos aprobados por la Academia. 1792.

763. Representación de la junta de gobierno sobre que la ciudad de México satisfaga los 20 pesos de la pensión respectiva a los años de 1791 y 1792 y que cn lo sucesivo la pague siempre en el día $1^{\text {o }}$ de enero cada año. 1792 y 1793.

Gaveta 7. 1793 (números del 764 al 821).

764. Lista con 48 temas clásicos. 1793.

765. Correspondencia en relación con la habilitación de buriles y demás útiles necesarios para las clases de grabado. Contribución de la ciudad. También contribuye a las pensiones de que disfrutan: Manuel López, José Mariano Picaso y Francisco Piso. 1793.

766. Cuenta de lo cobrado de las casas y sitio de Nilpantongo en el año de 1793 (ahora Palacio de Minería) y de lo erogado en la construcción de una cerca donde está el lavadero. 1793.

767. Asuntos para las pruebas de repente, de las Nobles Artes (lista). Lista de pensionados y discípulos, su edad, años de estudio y número de pieza.

Lista con el monto de premios.

Lista de las clases de pintura, escultura, arquitectura, grabado en láminas y en hueco y matemáticas. 1793.

768. Testimonio de la cscritura, en cuya virtud la Real Academia de las Tres Nobles Artes de San Carlos de esta Nueva España y en representación de ella su consiliario el señor marqués de Ciria, en conformidad de especial facultad, que se le confirió vendió el solar y casas arruinadas de Nilpantongo, frente al Hospital de San Andrés de esta capital, al Real Tribunal General de importante cuerpo de minería en precio de $\$ 30,000$ que se exhibieron en contado, cuya venta la hizo con precedente licencia del rey. 1793. 
769. Solicitud de don Antonio Carrera y Aramburu sobre que se le conceda nombramiento de agrimensor. 1793.

770. Solicitud de don Joaquín de Heredia sobre que se le conceda nombramiento de agrimensor. 1793.

771. Solicitud de don Francisco Ortiz de Castro presentando unos cliseños para que se le dé el grado a que fuese acreedor el mérito de la obra. 1793 (resuelta en el sentido de que se le dé grado de Académico de Mérito, por conformidad de Manuel Tolsá y Antonio Velázquez). 1793.

Dictamen de Gerónimo Antonio Gil. 1793 (Gil recomendó que se le permitiese hacer obras pero no se le diese grado de Académico de Mérito, por las razones que presenta).

772. Determinación de la Real Academia de crear Académico de Mérito a don Mariano Maella. 1793.

773. Sobre elección de Académicos de Honor. Listas y correspondencia. 1793.

774. Don José Mariano de León, opositor a la pensión vacante en el ramo de pintura. Consta ser español. Presentó los dibujos y se remitieron al conserje. 1793.

775. Don Mariano García, opositor a la pensión yacante en el ramo de pintura, consta ser español. Presentó dibujos y se remitieron al conserje. 1793.

776. Sobre mantener pensionados en Madrid. Pintura: José María Guerrero y José María Vázquez. Escultura: Manuel José López y Pedro Patiño Ixtolinque. Arquitectura: José Gutiérrez y Joaquín Heredia.

777. Solicitud de don Nicolás Flores sobre que se le dé certificación de haber cursado geometría y trigonometría en la Real Academia. 1793.

778. Memorial del ensayador don Antonio Forcada y la Plaza pidiendo se le den algunas piezas trabajadas por los pensionados y discípulos de la academia para habilitar la nueva escuela de dibujo establecida en Guadalajara. 1793.

779. El pensionado Ignacio Sandoval solicita licencia sin dejar en ella de trabajar. 1793.

780. Certificado del cirujano don Juan Durrey, sobre la enfermedad de don José Gutiérrez y solicitando se le dé licencia. 1793.

781. Solicitud del director don Ginés de Aguirre sobre permiso para mudar temperamento. 1793.

782. Memorial del director de pintura don Ginés de Aguirre solicitando se le vendan algunas brochas de las que vinieron para el uso de la Academia. 1793. 
783. Instancia del Académico de Mérito don Esteban González, sobre que se le despache título de Maestro de Delineación del Colegio Metálico. 1793.

784. Nueva instancia del reverendo P. F. Mariano de la Santísima Trinidad, ministro del Tercer Orden de Nuestra Señora del Carmen, sobre que se le permita abrir dos puertas colaterales a la principal en la capilla del mismo Tercer Orden. 1793.

785. Representación de los discípulos de matemáticas sobre que se les permita tener un acto de las materias relativas a esta ciencia. 1793.

786. Instancia del cura de la parroquia de San José sobre que en lugar de los arcos de las capillas interiores de la nueva fábrica de su iglesia, se subroguen dos puertas por los motivos que expone. 1793.

787. Instancia del director de matemáticas don Diego Guadalajara, sobre que los 200 pesos del aumento que se le hizo sobre 800 pesos que gozaba, aprobado ya por S. M. empiece a correrle desde el día de la asignación. 1793.

788. El director don Joaquín Fabregat avisa lo que ha quedado de la habilitación que se lizo a José Huertas. 1793.

789. Solicitud de don José Rafael de Larrañaga sobre que se le conceda nombramiento de agrimensor. 1793.

790. Renuncia de don Antonio Barroso de 10 pesos del premio que le tocó, en favor de la Real Hacienda. 1793.

791. Agradecimiento de Joaquín Gutiérrez de los Ríos por haber sido nombrado Académico de Honor. 1795.

792. Ramo de escultura. José María Evaristo García de Bores, español, natural de esta ciudad, pobre y huérfano de padres. Presenta su fe de bautismo, para obtener pensión. 1793.

793. Ramo de escultura: José Narciso de los Angeles Mártires, indio pretendiente a la pensión vacante. 1793.

794. Ramo de escultura. Felipe de la Cruz, indio, pretendiente a pensión. 1793.

795. Copia del edicto y orden para que se dé a conocer convocatoria a los opositores a pensión en el ramo de pintura. 1793 (dicha pensión la tuvo, Manuel García).

796. Copia del edicto y orden para que se dé a conocer convocatoria a los opositores en los ramos de escultura y arquitectura. 1793 (dichas pensiones habían sido tenidas por: Ignacio Sandoval y José María Arrospide).

797. Copia del edicto y orden para dar a conocer la convocatoria a los 
opositores del ramo de arquitectura. 1793 (dicha pensión la tuvo don Joaquín Heredia. Renunció).

798. Expediente sobre venta del solar de Nilpantongo al Real Tribunal de Minería por los mismos 30,000 pesos en que lo compró a don Juan Velázquez de la Cadena. 1793.

799. Compra de libros y útiles para la academia. Listas correspondientes. Encargo hecho a Antonio José Mosti. 1793.

800. Acuses de recibo de las medallas de la academia. 1793.

801. Solicitud del director de arquitectura don Antonio Velázquez, sobre que se le dé alguna gratificación por el trabajo que emprendió en componer la casa de academia. 1793.

802. Memorial del discípulo don Juan José García pidiendo se le dé alguna gratificación por el trabajo que emprendió en formar los planos de la casa de academia. 1793.

803. Solicitud del conserje don Diego Mestre y Pardo, sobre que se le den los finiquitos de las cuentas que presentó de la obra material de la academia 1793.

804. Sobre reconocimiento y rectificación de planos del Lazareto de Veracruz y Hospital de Sombrerete. 1793.

805. El director de matemáticas don Diego de Guadalajara y Tello solicita quince días de licencia para curarse. 1794.

806. Real Orden sobre la asignación de 200 pesos hecha por el director don Rafael Ximeno y Planes, a su madre y hermana. 1793.

807. Real Orden para que se le aumente el sueldo al director de matemáticas a 2,000 pesos anuales. 1793.

808. Encargo de que se compren en España obras de pintura y útiles para la academia. 1793.

809. Aviso del real nombramiento de don Rafael Ximeno, Académico de Mérito y teniente director honorario de la de Valencia, para director de pintura. 26 de noviembre 1793.

810. Aviso de haber entregado en Madrid a don Rafael Ximeno 600 pesos a cuenta de su sueldo de 2,000 pesos, como director de pintura de la academia. 26 de noviembre 1793.

811. Superior orden acompañando 22 ejemplares del diario del comandante de la expedición de límites de Californias, para que se trasladen por los dependientes inteligentes.

812. Superior orden acompañando 10 mapas para que se saque copia de ellos. 1793.

813. Aviso de la muerte del Académico de Honor don Juan Eugenio Santelicer Pablo. Lo avisa su sobrino José María Santilicer. 1793. 
814. Oficio del excelentísimo señor virrey Revillagigedo, participando hallarse arrestado en esta Real cárcel el pensionado de arquitectura José Arrospide. 1793.

815. Se piden datos sobre la fundación de la academia, su destino, rentas, gastos, sujetos empleados en ella, etcétera, para incluirlos en una guía política, militar y eclesiástica de esta Nueva España. 1793. Revillagigedo va a hacer una guía completa. Se remiten los informes.

816. Se avisa que cumpliendo la orden de 25 de septiembre de 1793 ya se procede a formar inventarios. 1793.

817. Orden para que se convoque a junta general para distribución de premios el día 9 de diciembre de 1793, cumpleaños de la reina. Revillagigedo. 7 de diciembre de 1793. Lista de alumnos premiados.

818. Informe del director don Gerónimo Antonio Gil sobre la gratificación que se deba dar a don Tomás de Surín por haber dibujado su retrato. 1793.

819. Oficio de don Joaquín Fabregat para que no se dé permiso a sus discípulos Julián Marchena y Mariano del Águila para hacer trabajos particulares. 13 de marzo de 1794. Carta de Mariano del Aguila a don Joaquín Fabregat, avisándole que renuncia a su pensión.

820. Oficio del señor virrey Revillagigedo transcribiendo el de don Pedro Acuña en que avisa haber distribuido las medallas que se mandaron. 4 de abril de 1794.

821. Representación del P. Procurador del Convento de Carmelitas sobre el perjuicio que se le sigue de variar la obra de la capilla de la Tercera Orden. 1793.

Gaveta 8. 1794-1795 (números del 822 al 906).

822. Sobre costo y gastos de cuatro tomos de a folio Tratado de Arquitectura por Paladio, remitidos para la Real Academia por don Gabriel de Sancha, librero de Madrid. 1794.

823. Revillagigedo remite a la Real junta de la academia una exposición de don Joaquín Fabregat, director de grabado, para que se le continúe la gratificación que le estaba asignada por el trabajo extraordinario de enseñar estampado. Pide informe sobre lo que parezca conveniente. 10 de abril de 1794 . 
823 bis. Exposición de don Joaquín Fabregat sobre el asunto anterior. Abril de 1794.

824. Memorial del indio Juan de la Cruz Fortes, del ramo de escultura, sobre que se le obligaba a pagar tributo. 1791 .

Real Orden relevando a los indios pensionados de la Real Academia de San Carlos del pago de tributo. $1^{\circ}$ de julio de 1794.

825. Don José María Vázquez, discípulo pensionado, solicita ser nombrado para hacer las obras que se le han ocurrido. Junio 2 de 1794 (ramo de pintura).

826. Los pensionados José María Guerrero y José María Vázquez, solicitan se les permita trabajar obras particulares por sí solos. Marzo 22 de 1794 (ramo de pintura).

827. José Gutiérrez y Juan Sánchez, alumnos de la Real Academia, ramo de arquitectura, solicitan que no se les quite la pensión que tenían asignada. Febrero 5 de 1794.

828. Informes de los directores de la Real Academia sobre si es útil o no el que los pensionados hagan las obras que se les puedan ocurrir.

Informan: Ginés de Andrés y de Aguirre, Manuel Tolsá, Diego de Guadalajara, Joaquín Fabregat, Antonio Velázquez. Abril de 1794 (interesante).

829. Expediente sobre las dos vacantes de consiliarios, por muerte de don Juan Lucas de Lazaga y de don José Ângel de Cuevas y Aguime, respectivos a la nuestra ciudad y Real Tribunal de Minería.

Propuestos: Don José González de Castañeda.

Don Felipe Antonio Teruel.

Don Antonio Rodríguez de Velasco.

Nombrados consiliarios de la junta:

Don José González de Castañeda.

Conde de Contramina.

Julio de 1794.

830. Nombramiento de los consiliarios don Francisco Fernández de Córdoba, don José Fernández de Uribe y don Manuel de Âlava. 1794-1795.

831. Nombramiento de presidente de la Real Academia de San Carlos. Don Ramón de Posada, presidente que fue, entregó la llave del arca a don Antonio Barroso, consiliario decano. 14 de marzo. 
Propuestos: Francisco Fernández de Córdoba.

$$
\begin{aligned}
& \text { Fausto de Elhuyar. } \\
& \text { Migucl Constansó. }
\end{aligned}
$$

Se nombró al primero. Marzo 27 de 1794.

832. Instancia de los directores de las Tres Nobles Artes, sobre asignación de lumbreras en las fiestas de toros. Noviembre 17 de 1794.

833. Solicitud del profesor de pintura, don José Camarón, sobre que se le permita hacer alguna obra de su mano para esta Real Academia. Noviembre de 1793. Aceptado en 26 de abril de 1794 (Camarón era profesor en Madrid).

834. Solicitud de don Francisco Ortiz de Castro, Académico en el ramo de arquitectura, para que se le permita ejercer su facultad mientras se examina. Julio 1794 (?) (sin fecha).

835. Don José Gutiérrez, pensionista del ramo de arquitectura, presenta planos y dibujos para que se le dé título de Académico de Mérito. Se le nombró el 7 de julio de 1794.

836. Don Joaquín de Heredia solicita se le nombre Académico de Mérito en el ramo de arquitectura. Presentó planos para el edificio de una nueva universidad. Certificado favorable de don Miguel Constansó. Se le nombró el 28 de febrero y tomó posesión el 31 de marzo de 1794.

837. Don Francisco Gordillo, grabador mayor de la Real Casa de Moneda presentó obra y solicita nombramiento de Académico de Mérito. 1794 (?) (sin fecha).

838. Instancia de don José Rodríguez Alconedo para que se le conceda el grado de Académico de Mérito. Presentó el retrato de Carlos IV. Junio 25 de 1794. Ramo de grabado.

Informe de Manuel Tolsá, no sólo favorable sino elogioso.

Se acordó favorablemente el 9 de julio de 1794; se le comunicó el 24 de julio. Enterado, Branciforte, 15 de julio.

(Esta obra labrada en plata se conserva en el Museo Nacional de Historia. Castillo de Chapultepec. 1945. Nota de J.F.)

839. Solicitud de la señora doña María Guadalupe de Moncada y Berrio para que una copia que presenta, pintada al b́leo, de su mano se coloque en esta Real Academia.

En junta de 9 de julio de 1794 se acordó nombrarla Académica de Honor y Mérito y directora honoraria en el ramo de pintura "por aclamación general con motivo de haber presentado una obra 
al óleo de su mano, hecha con todos los primores y reglas del arte que aprobaron por estar perfecta..."

Enterado. Branciforte 15 de julio de 1794.

840. La junta declaró vacante la pensión que obtenía en el ramo de arquitectura don José Herrera por su conocida inutilidad para este arte. Febrero 18 de 1794.

841. Opositores a la pensión vacante en el ramo de arquitectura: José Avila Roxano, Juan José García Iurrieta y Diego Pérez Valdés. Agosto 2 de 1794. Presentaron planos.

Informaron: Gerónimo Antonio Gil, Manuel Tolsá, Antonio Velázquez, Diego Guadalajara y Tello, Joaquín Fabregat, Rafael Ximeno y Planes.

842. Representación del discípulo don José Mariano de Herrera sobre la pensión que se le quitó. Febrero 22 de 1794 . Certificado de la junta abril 20 de 1794 sobre capacidad en dibujo.

843. Solicitud para pensión. Luis de Tola y Salcedo. Español de 19 años de edad. Ramo de arquitectura. Certificado de autenticidad de trabajos presentados. Antonio González Velázquez. 1794.

844. Solicitud para pensión. Diego Pérez Valdez, español de 17 años de edad. Ramo de arquitectura.

Certificado de autenticidad de trabajos presentados. Antonio González Velázquez. 1794.

845. Solicitud para pensión. Juan José García Iturrieta, español de 22 años de edad. Ramo de arquitectura.

Certificado de autenticidad de trabajos presentados. Antonio González Velázquez. 1794. 1 ${ }^{a}$ y $2^{\text {a }}$ prueba. Mayo y julio de 1794.

846. Solicitud para pensión. José Mariano Mendoza. Ramo de arquitectura. 1794. Informe del presidente de la Real Academia recomendando se dé la pensión a Mendoza. Agosto 26 de 1794. Oficio del virrey Branciforte para que se proceda a la votación y se dé la vacante al joven opositor más benemérito a quien corresponda de justicia. Septiembre 19 de 1794.

847. Remisión y acuse de recibo del virrey Revillagigedo, de la entrada y salida de caudales de la Real Academia durante el año de 1793. 6 y 7 de febrero de 1794 .

848. Superior resolución sobre una ordenanza de inválidos que debe haber en la Real Academia con gratificación de 5 pesos mensuales. Enero 28 de 1794.

(Un soldado del cuerpo de inválidos que cuide de evitar el distraimiento de los jóvenes.) Por petición del conserje de la academia. 
849. El director de arquitectura, Antonio González Velázquez, solicita se nombre un académico de Mérito que le substituya: recomienda a don José Gutiérrez para atender la sala cuando él se ausente. Julio 29 de 1794.

850. Superior Orden sobre copia de doce planos del proyecto de camino de Veracruz a Perote. Revillagigedo. Mayo de 1794.

851. Informe del director general de la Real Academia, don Gerónimo Antonio Gil, sobre los planes que propuso para el adelanto de los discípulos y oposición que encontró para verificarlos. Capacidad de los directores, auxilios que necesitan para las correcciones y método que debe adoptarse y sobre si es útil o no el que los pensionados hagan las obras que se les puedan ocurrir, dice parecerle conveniente se les conceda medio día para que se ocupen en ellas, imponiendo a los maestros la obligación de corregirlas para que salgan perfectas. Abril 26 de 1794 . (Importante hace la historia de sus esfuerzos desde que empezó a enseñar dibujo en la Casa de Moneda y hace la crítica de los directores y discípulos así como varias recomendaciones. El documento es un verdadero resumen, dictado por el celo apasionado de Gil, de las condiciones de la Real Academia en 1794.)

852. Expediente y disposición del virrey Revillagigedo para arreglar las horas de asistencia de los aprendices y oficiales de platería y que se pague al velador. Julio de 1794.

853. Cartas de don Ramón de Posada relativas a la lámina de títulos de académicos, según diseño formado por don Cosme de Acuña, para ser grabada en Madrid. Encargada a don José Moreno Texada, grabador. Marzo de 1794.

(Posada fue a Madrid con el encargo, llegó allí en noviembre. En sus dos cartas desde Madrid habla de algunos cuadros encargados para la academia.)

854. Oficio del virrey Revillagigedo transcribiendo el de Eugenio de Llaguno: Real Orden sobre que en las colecciones de pinturas del reino hay cuadros duplicados de los pedidos por la academia. Julio 10 de 1794.

855. Oficio al virrey Branciforte ofreciendo los servicios de la academia y solicitando su protección. Junio 18 de 1794.

856. Superior Orden sobre que se hagan dos dibujos diversos por los alumnos de la academia para conocer sus adelantos. Mayo 18 de 1794. Revillagigedo. Se enviaron 56 dibujos. 26 de junio de 1794.

857. Petición del director de pintura, don Rafael Ximeno, para que se 
mejoren las condiciones de las salas de estudio destinadas a su ramo. Agosto de 1794.

858. Superior Orden acompañando cinco perfiles de la obra del Real desagüe para que se copien con toda perfección. Junio de 1794.

859. Instancia de don Bernardo Galindo sobre que se le dé certificación de haber cursado en la academia y hecho sus progresos en ella. Agosto de 1794.

860. Representación de los discípulos Manuel López y José María Montes de Oca para que se les habilite de lo que les falta para el uso de su arte. Ramo de grabado en hueco. Septiembre de 1794.

861. Representación del director de matemáticas don Diego Guadalajara sobre lo conveniente que será nombrar a don José Pulgar para sustituto suyo en lugar de los cuatro que hasta aquí ha habido. Septiembre 27 de 1794.

862. Solicitud de licencia, de don José María Guerrero, para mudar temperamento por dos meses. Certificado médico. Junio 28 de 1794.

863. Francisco Lindo presenta la prueba de su primer lámina grabada y solicita se juzgue como prueba para la oposición de la clase de adornos. 1794.

864. Orden de que se dé a la Real Academia dos mil pesos adeudados por la pensión vencida. Revillagigedo. Enero 23 de 1794.

865. Memoria presentada por don Antonio González Velázquez, director de arquitectura, sobre lo gastado en varias reparaciones en las salas de pintura. Octubre 11 de 1794.

866. Pedro Patiño Ixtolinque solicita permiso para hacer un Cristo que le han encomendado. Ramo de escultura. 1794.

867. Renuncia que hizo Julián López Marchena de la pensión que tenía. 1795.

868. Renuncia que hizo José María Guerrero de la pensión que obtenía en el ramo de pintura. Junio de 1795.

869. Don José Buitrón y Velasco, Académico de Mérito en el ramo de arquitectura solicita aprobación de planos para la fábrica de una casa en la calle de Santa Catalina, esquina de la plazuela del mismo nombre. Enero 26 de 1795.

Revisión y observaciones de don Miguel Constansó. Enero 28 de 1795.

870. Instancia del Académico de Mérito don José Gutiérrez sobre que se le conceda una hora por la mañana para asistir a la nueva fá- 
brica de tabacos, como ayudante de su director don Miguel Constansó. Julio 31 de 1795.

871. El director de escultura don Manuel Tolsá cede a la Real Academia los estudios que posee, como también los moldes de figuras y colección de 300 medallas. Mayo 2 de 1795.

872. El director de escultura don Manuel Tolsá escribe sobre lo útil que sería sacar moldes de la colección de estatuas y bustos que tiene la Real Academia; pide licencia para sacarlas, de algunas; siendo de su cuenta los gastos y quedando su obligación de reponer las figuras de que se sacaren de los moldes. Enero 29 de 1795.

"Deseando el mayor y más pronto adelantamiento de las Artes que están bajo la protección de $\mathrm{V}$. E. hago presente que uno de los más eficaces medios es la propagación del buen gusto, pues sin este son casi inútiles las Bellas Artes, las que tratadas sin el aprecio que es hijo de un delicado discernimiento se sepultan en la ignorancia..."

873. Oficio del virrey Branciforte al presidente de la junta sobre que los directores de escultura, arquitectura y pintura ocurrieron al rey pretendiendo alternar en la dirección general de la Real Academia, pero por Real Orden de 25 de noviembre de 1794 , S. M. no ha tenido por conveniente concederles tal gracia, debiendo continuar con la indicada dirección don Jerónimo Antonio Gil, cuya particular gracia se dignó concederle en consideración al mérito de haber establecido la academia. Abril 15 de 1795.

874. Superior Orden para que se informe a S. E. reservadamente sobre el método de estudios que se siguen en ella; si se observan puntualmente los estatutos y si conforme a ellos asisten los directores. Abril 15 de 1795. Se incluye en el expediente el informe con los métodos de estudios y asistencia de directores perısionados y demás discípulos (importante).

875. Representación de los Académicos de Mérito don Esteban González, don Joaquín de Heredia y don José Gutiérrez, sobre que los que obtuvieron por gracia particular título de Académicos de Mérito, presenten los diseños antes de principiar las obras. “. . . Las más que hasta la fecha han ejecutado (don Ignacio Castera, don José Mazo, don Joaquín Torres y don José Velasco, por gracia particular en el Gobierno del Exmo. Sr. Dn. Manuel Antonio Flores) han sido sin este requisito, contraviniendo a lo mandado como que carecen de estudio..." Febrero 27 de 1795.

876. Memorial de los Académicos de Mérito en el ramo de arquitectura, don Joaquín de Heredia y don José Gutiérrez sobre que se les nombre para tasaciones, medidas y reconocimientos que se hayan de 
haccr, conforme al artículo 9 , capítulo $3^{\circ}$ de los estatutos. Noviembre 28 de 1795.

877. Representación de los directores de pintura y escultura sobre que se les permita alternar por semanas o por meses en las horas de estudio para la corrección de los discípulos, en los términos que indican. Abril 29 de 1795. Rafael Ximeno, Ginés de Andrés y de Aguirre. Manuel Tolsá.

878. Solicitud de don Saturnino Samaniego a la plaza de substituto a la segunda sala de matemáticas, vacante por renuncia del que la poseía.

879. Solicita licencia para casarse don José María Montes de Oca, pensionado del ramo de grabado en hueco (era su presunta esposa doña María Josefa Valdés. Montes de Oca tenía ya una niña). Enero de 1795.

(Números 880 a 889 cancelados.)

890. Don José Gutiérrez, Académico de Mérito de la Real Academia, solicita se le entreguen para sacar copia los diseños que presentó, en calidad de devolverlos. Mayo 19 de 1795.

891. El pensionado don José Guerrero, del ramo cle pintura, solicita uno o dos meses de licencia para curarse. Abril 30 de 1795.

892. Memorial de los pensionados en el ramo de grabado en hucco, Manuel Lópcz y José María Montes de Oca sobre que se les habilite de marcos y cristales para colocar las obras que executaron de orden de S. E. (Para unas medallas de yeso, que les pidicron para presentar.) Sin fecha.

893. Manuel López, sobre devolución de la multa de la mitad de la pensión que se le impuso por un mal clibujo que hizo. Ya que sc estropeó por estar hecho en carbón. Sin fecha.

894. Don Juan José García discípulo pensionado sobre que se le devuelva la multa que se le impuso por no haber prescntado diseños a satisfacción de la junta. Ya que no tenía los instrumentos necesarios. Los pide González Velázquez dice que es justificado. $1^{\circ}$ de abril de 1795.

895. Solicitud de don Saturnino Samaniego sobre que se le conceda una pensión vacante en el ramo de arquitectura. Sin fecha.

Renuncia de don Satumino Samaniego a la pensión que goza, y al puesto de sustituto en la sala de matemáticas por tener que pasar a servir en el ejército. Sin fecha.

896. Sobre examen de don José María del Valle para ejercicio de agrimensor. Aprobado el 6 de febrero de 1795. 
897. El director de matemáticas don Diego Guadalajara y Tello, es comisionado para pasar al Real de Tepantitlan a reconocer la mina de Santa Ana, propia del señor conde de la Contramina y la de Dolores del regidor alguacil mayor, don Joaquín Romero de Caamaño. $1^{\text {o }}$ de julio de 1795 .

898. Instancia del discípulo don José Pulgar, ayudante del director de matemáticas sobrc que se le den mensualmente los mismos doce pesos asignados a los ayudantes de pintura. $1^{\mathbf{0}}$ de agosto de 1795.

899. Sobre la aprobación de los planos para la fábrica de dos casas en esta capital presentados por el Académico de Mérito don José del Mazo Avilés. Son dos casas de vecindad, pertenecientes al convento de San José de Gracia, una en la calle de dicho convento y la otra en la del Puente de Santo Domingo. Sin fecha.

En otra carta adjunta, reclama algunas de las correcciones que se le hicieron diciendo que no es necesario que los vanos y los macizos sean siempre iguales, "si no, no habría portales".

900. Consulta de la Real Academia al excelentísimo virrey sobre multa que debe imponerse al arquitecto don José del Mazo Avilés. Por haber construido una casa en la calle del Ángel sin presentar planos y por no haberse sujetado en la capilla de la Tercera Orden del Camen a los planos aprobados por la academia. Sin fecha.

901. Don José Pulgar sobre examen de agrimensor para este reino. Aprobado el 19 de agosto de 1795.

902. Instancia de don Juan Moreno Tejada, grabador de láminas en Madrid, Acadćmico de Mérito de la Real de San Fernando y San Carlos de Valencia, pidiendo se le conceda igual gracia en esta academia.

Carta de Tolsá diciendo que Moreno Tejada le mandó seis estampas para obtener el título y que además está grabando el título de académicos.

903. Superior Orden sobre que se remitan diseños hechos por los alumnos, para que la superioridad pueda hacer las advertencias necesarias. Orden del virrey Branciforte para que se le pasen 24 de abril de 1795. Se le pasan tres cajones con obras. 2 de febrero de 1796. Branciforte dice que remitirá a S. M. las obras. 4 de febrero de 1796.

904. Superior Orden sobre la satisfacción de media anata siempre que se libre algún examen o título. Branciforte. 21 de enero de 1795.

905. Sobre la instancia de don Bruno Larrañaga sobre la provisión de copra? 13 de julio de 1795 . 
906. Solicitudes para ser admitidos por discípulos en la Real Academia de San Carlos. 1795 (numerosas solicitudes).

Gaveta 9. 1796-97-98-99-800 (números del 907 al 1035).

907. Cuatro certificados de estudios de Mariano Isidoro Retama y Martínez. Abril de 1796.

908. Expediente sobre la obra de desagüe de la Laguna de Zumpango, proyectada por don Cosme de Mier, delineada por don Diego Guadalajara, director de matemáticas de la Real Academia. Abril 1796.

909. Oficio de S. E. aprobando el nombramiento de conserje don Manuel Mestre. Noviembre 1796. Branciforte.

910. Informe de los directores de la Real Academia sobre el plan de estudios que debía adaptarse para que los discípulos aprendiesen las respectivas facultades y reglas y principios sólidos. 1796. Jerónimo Antonio Gil. Antonio Velázquez. Joaquín Fabregat. Manuel Tolsá. Diego de Guadalajara (importante).

911. Lista de las ciudades y villas, ilustrísimos señores obispos y Cabildos y otros particulares que no contribuyeron para el establecimiento de la academia. 1796.

912. Consulta hecha al excelentísimo señor virrey marqués de Branciforte, proponiendo para Académicos de Honor a los sujetos siguientes: don Juan Antonio Riaño, intendente de la provincia de Guanajuato; don Antonio de Mora y Peysal, intendente de Oaxaca; don Gaspar Cándamo, canónigo de la Santa Iglesia de Guadalajara y licenciado Fernando Pérez Marañón, alférez Real de la ciudad de Guanajuato. Febrero 17 de 1796. “... Considerando muy oportuno que esta Real Academia tenga en las ciudades foráneas algunos sujetos de distinción, condecorados ..."

913. Aprobación de S. E. de los Académicos de Honor y consiliarios propuestos por la Real Academia. Febrero 27 de 1796.

Consiliarios: don Ciriaco González Carbajal; don Rafael Bachiller y Mena.

Académicos de Honor: don Andrés Mendivil; licenciado Andrés Fernández Madrid; don Bartolomé Sandoval; don José María Barrios; don Manuel Antonio Flores.

914. Instancia del pensionado don José María Vázquez sobre que se le amplíe el tiempo de su pensión por los justos motivos que expresa. Agosto 2 de 1796.

915. Oficio del ensayador mayor don Antonio Forcada y la Plaza, pidiendo se le remita certificación de haber asistido a la academia el apren- 
diz de platero Ignacio Sánchez, para los efectos que indica. Julio 12 de 1796.

916. Instancia del director de escultura don Manuel Tolsá sobre que se le conceda el grado de Académico de Mérito en el ramo de arquitectura, acompañando para el efecto los planos que indica. Año de 1796 (sin fecha) (importante).

917. Contestación del señor regidor en turno don José Mariano Fagoaga, al oficio que se le pasó con la noticia de haberse nombrado Académico de Mérito en el ramo de arquitectura al director de escultura, don Manuel Tolsá.

Al señor marqués de San Jorge.

"Queda instruida esta Real Junta de Policía, por el oficio de V.S. de 5 del corriente, quedar nombrado Académico de Mérito en el Ramo de Arquitectura Dn. Manuel Tolsá, para tenerlo presente en los casos que ocurran relativos a su arte." Octubre 10 de 1796.

918. Oficio del virrey Branciforte anunciando su visita para ver la efigie ecuestre de S. M. que ha de colocarse el 9 de diciembre en la Plaza Mayor, mientras se verifica la fundición en bronce. Octubre 11 de 1796. Branciforte.

919. Sobre que el catedrático de matemáticas, don Diego Guadalajara, acompañe al director de arquitectura don Antonio González Velázquez a la práctica de medidas, nivelaciones, etcétera del camino antiguo de esta capital a Puebla. Diciembre 16 de 1796. Branciforte.

920. Memoria del director de arquitectura don Antonio Velázquez, pidiendo licencia para pasar a ejecutar varias operaciones en el camino de Veracruz acompañado del director de matemáticas don Diego Guadalajara y del pensionado don Mariano Bustamente. Diciembre 31 de 1796.

921. El director de arquitectura don Antonio Velázquez, participa haber nombrado, en virtud de Superior Decreto, para dirigir el re-edificio del Molino de Tulancingo a don Luis de Tola. Aprobación del señor presidente. Abril de 1796.

922. Sobre fuero que reclama el maestro mayor de arquitectura, don Antonio de Santa María Incháurregui. Octubre 20 de 1796.

923. Expediente sobre solicitud de don Antonio de Santa María Incháurregui para que se le dé título de agrimensor. Contestación del presidente: que se presente a examen. 1746-1797.

924. El señor intendente de Puebla, sobre reconocimiento y aprobación de los planos de unas casas (con dos dibujos de fachadas). Septiembre 13 de 1796 (Incháurregui. Opinión de Antonio Velázquez). 
925. Instancia del discípulo Francisco Xavier Tello de Orozco, sobre que se le conceda una pensión vacante en el ramo de escultura. Marzo de 1796.

926. Renuncia que hizo don Joaquín de Heredia, de la pensión que obtenía en el ramo de arquitectura. 1796.

927. Minuta de una carta (sin firma) acerca de $\$ 80,000$ que la junta superior de gobierno acordó se redimiesen sobre la Real Hacienda, con hipoteca de la renta del tabaco, que le reconocía el Real Tribunal de Minería. Noviembre 20 de 1797.

928. Oficio del Real Tribunal de Minería para que por esta academia se reciban los $\$ 80,000$ que reconoce a su favor y se le devuelva cancelada la correspondiente escritura; previniendo que si se quisiese hacer su imposición en Real Hacienda admitirán esta cantidad a cuyo fin se hallan autorizados. Manuel García de Zevallos. Bruno María de Noriega. Francisco González de la Vega. Octubre 16 de 1797.

929. Oficio del Real Tribunal de Minería en que se participa haber entregado a la Tesorería de la Real Hacienda los $\$ 80,000$ que reconocía a favor de esta Real Academia; pidiendo se le devuelva cancelada la escritura de reconocimiento que otorgó a su favor. Noviembre 29 de 1797.

930. Oficio de Silvestre Díaz de la Vega al arquitecto José Gutiérrez comunicándole la orden del excelentísimo virrey por la cual se le nombra para que cuide de la dirección de la obra de la fábrica de tabaco de esta capital, durante la ausencia del coronel de ingenieros don Miguel Constansó y del director de arquitectura don Antonio González Velázquez. Enero 20 de 1797.

931. Oficio de Silvestre Díaz de la Vega al arquitecto José Gutiérrez contestando al de éste en que preguntaba sobre qué era lo que debía dirigir en la construcción de la fábrica de tabaco. La contestación fue que "Como inteligente cuide de la conservación de lo fabricado por medio del riego, para cuyo fin se destinan seis peones". Febrero $1^{\circ}$ de 1797.

932. Oficio de Silvestre Díaz de la Vega al arquitecto José Gutiérrez comunicándole la orden del virrey sobre que en vista de que han regresado a esta capital tanto el arquitecto González Velázquez, director de arquitectura de la Real Academia de San Carlos y segundo del edificio de la fábrica de tabaco, como el coronel de ingenieros don Miguel Constansó, cesó también el encargo del arquitecto José Gutiérrez para que corriere con la dirección y cuidado de la obra. Febrero 20 de 1797. 
933. Oficio del arquitecto Antonio González Velázquez al arquitecto José Gutiérrez comunicándole que en vista de que él está muy ocupado en las obras del camino de Veracruz, de la Real Casa de Moneda y Apartado y en la dirección de la Real Academia, que deberá quedar con el encargo de vigilar la obra de la fábrica de cigarros, yendo dos veces por semana y dándole aviso de cualquiera novedad. Febrero 22 de 1797.

934. Memorial de don Vicente Garviso, agente de negocios titulado por el gobierno, como apoderado del arquitecto José Gutiérrez, Académico de Mérito de la Real Academia de esta capital y residente en Guadalajara, en que explica los antecedentes de su apoderado y sus méritos y servicios en la Real Academia, como substituto del director de arquitectura y en la fábrica de tabaco (11 años en el primer cargo y 2 en el segundo); que después pasó a Guadalajara solicitado por el ilustrísimo señor doı Juan Cruz Ruiz de Cabañas, obispo de Guadalajara y a propuesta del director de escultura don Manuel Tolsá, para dirigir la obra material de una casa de Misericordia (Hospicio Cabañas), pero que no renunció a sus derechos de 20 años de servicios a la Real Academia y le fue concedida licencia (23 de febrero de 1805). Que en vista de todos sus méritos y servicios solicita se le confiera la plaza de director de la Real Academia de San Carlos que está vacante por muerte de don Antonio Velázquez. 1806 (?) (importante).

935. Memorial del Académico de Mérito don José Gutiérrez encargado por su E. de las obras de las garitas altas y del caso de esta ciudad, pidiendo que para llenar esta comisión se le concedan dos días naturales en cada semana. Marzo 30 de 1797.

936. Oficio del Secretario de la junta de unión de rentas y resguardos, licenciado José María Arce y Echegaray, comunicando el nombramiento del arquitecto José Gutiérrez, substituto de don Miguel Constansó en las obras de garitas altas y bajas. Abril 22 de 1797.

937. Memorial del arquitecto don José García de Torres presentando para su aprobación los planos de dos casas en las calles de Santo Domingo, con el informe que hizo en el asunto el director de arquitectura, Antonio Velázquez. Septiembre de 1796.

938. Informe de don Antonio Velázquez sobre los planos presentados por don José Joaquín García de Torres para las obras de las casas de la calle de Santo Domingo y Mesón de la Pila Seca. Dice: "que no se me ofrece que advertir nada por hallarlos arreglados." En cumplimiento de lo ordenado por el señor marqués de San Jorge, presidente de la Real Academia. Febrero 6 de 1797. 
939. Solicitud del guardián del convento grande de San Francisco de esta capital, fray Manuel de Aranda, para que se comisione al director de arquitectura, para que informe por escrito sobre la obra de pavimento y nuevo presbiterio que están haciendo. Agosto de 1797.

940. Informe del arquitecto don Manuel Tolsá sobre que está ejecutando en el convento grande de San Francisco de esta capital. Agosto 21 de 1797.

941. Informe del arquitecto don Antonio González Velázquez sobre la obra que se está ejecutando en el convento grande de San Francisco de esta capital. Agosto 26 de 1797.

942. Oficio de don Baltasar Ladrón de Guevara pidiendo se devuelva a la Secretaría de Cámara del virrey el expediente sobre compra de una casa de don Sebastián Bobadilla, vecino de Veracruz, una vez ratificados los planos que contiene por el director de arquitectura de la Real Academia. Marzo 13 de 1797.

943. Superior Orden concediendo al director de arquitectura don Antonio Velázquez permiso para que cada dos meses pase a reconocer la obra del nuevo convento del Desierto, que ha de hacerse en los Montes de Niscongo. Branciforte. Orizaba, diciembre 18 de 1797.

944. Oficio de don Baltasar Ladrón de Guevara, como delegado del virrey Branciforte, trasladando la solicitud de don José Loreto Villanueva para que se le permita hacer los avalúos e inventarios que se ofrezcan. Abril 10 de 1797.

945. Oficio del secretario perpetuo de la Academia de San Carlos, capitán Antonio Piñeiro, certificando que habiéndose visto en junta de 29 de agosto, la solicitud de don José Loreto Villanueva sobre que se le dé grado de Académico en el ramo de arquitectura, con el plano presentado y el informe del director Antonio Velázquez se acordó concederle facultad para dirigir y ejecutar las fábricas que se ofrezcan fuera de esta capital, presentando antes los planos a esta Real Academia a fin de que se examinen y aprueben. Septiembre 9 de 1797.

946. Memorial de don José Loreto Villanueva, vecino de la ciudad de Guanajuato, maestro alarife en ella, con aprobación de la Real Academia, al fiscal de lo civil, solicitando se le conceda facultad para hacer avalúos e inventarios que se ofrezcan.

947. Remisión del memorial de don José Loreto Villanueva (documento 946) a la Real Academia, para que informe. Marzo 11 de 1797.

948. Don Cosme de Mier y Trespalacios envía al presidente de la Real Academia el expediente sobre la construcción del camino de Atlixco a Puebla, para su examen. Julio de 1797. 
949. Informe de don Antonio González Velázquez sobre el expediente del camino de Atlixco a Puebla (dibujo imaginario y presupuesto. Comparación con el costo de otros caminos). Septiembre $1^{9} \mathrm{de}$ 1797.

950. Minuta del oficio del presidente de la Real Academia, marqués de San Jorge al señor don Cosme de Mier y Trespalacios, devolviéndole el expediente sobre el camino de Atlixco a Pucbla y copia certificada del informe del director de arquitectura (documento 949). Septiembre 5 de 1797.

951. Superior orden acompañando dos planos, una carta geográfica y una esférica, para que se saquen tres copias. Branciforte, noviembre 13 de 1797.

952. Acuse de recibo de Branciforte de la carta y copias de los planos que mandó sacar a la Real Academia. Branciforte. Enero 25 de 1798.

953. Examen de don Antonio Teodoro de Estrada para título de agrimensor, en que resultó aprobado. Diego Guadalajara y Tello. Antonio Velázquez. Julio 8 de 1797.

954. Copia del certificado de aprobación del examen de don Antonio Teodoro de Estrada, para título de agrimensor. Julio 11 de 1797.

955. Oficio de don Baltasar Ladrón de Guevara al presidente de la Real Academia, adjuntándole escrito de don Antonio Teodoro de Estrada, para que disponga su examen de agrimensor. Julio 3 de 1797.

956. Oficio al oidor don Cosme de Mier y Trespalacios, sobre el examen para título de agrimensor, en que fue aprobado el solicitante don Mateo de León Caballero y Ontiveros. Octubre 7 de 1797.

957. Certificado de aprobación en el examen para título de agrimensor de don Mateo de León Caballero y Ontiveros. Diego de Guadalajara y Tello. Antonio Velázquez. Septiembre 26 de 1797.

958. Oficio del señor oidor decano don Cosme de Mier, acompañando la instancia de don Saturnino Samaniego y Enderica para presentar examen de agrimensor. Agosto $1^{\circ}$ de 1797.

959. Certificado del examen de don Saturnino Samaniego y Enderica, para título de agrimensor, en que resultó aprobado. Diego Guadalajara y Tello. Antonio Velázquez. Agosto 8 de 1797.

960. Minuta del oficio de remisión del certificado del examen para agrimensor de don Saturnino Samaniego y Enderica, al señor don Cosme de Mier. Agosto 16 de 1797.

961. Instancia del discípulo don José de Ávila Roxano sobre que se le conceda una pensión vacante en el ramo de arquitectura. 1797. 
962. Certificado de bautismo de José de Ávila Roxano, español. Diciembre 3 de 1786.

963. Certificado de Antonio Velázquez sobre que los dibujos presentados por su discípulo don José Ãvila, fueron hechos en la academia en presencia suya. Mayo 22 de 1797.

964. Instancia del discípulo Donaciano Guerrero, oponiéndose a una pensión vacante en el ramo de grabados en hueco y presentando su fe de bautismo (español).

965. Fe de bautismo de Donasiano Guerrero (copia) (español).

966. Instancia de don Rafael José Gallegos sobre que se le admita en oposición a una pensión vacante en el ramo del grabado de láminas, acompañando certificación de su bautismo. 1797 .

967. Certificado de bautismo de Rafael José Gallegos. 1797.

968, 69, 70. Instancia de don Mariano Retama, don Luis Tola y don José de Ávila Roxano sobre que se les dé la plaza de substituto de la segunda sala de matemáticas, vacante por renuncia de don José Pulgar. 1797.

971. Oficio de don José María Rodallega al presidente, participándole, que los aprendices de platería no quieren asistir de noche a la academia por temor de que los aprehendan para la leva, a fin de que tome la providencia conveniente. Junio 28 de 1797.

972. Minuta de la carta de la Real Academia al virrey Branciforte, expresando sus sentimientos por su regreso a España. 1797.

973. Carta del virrey Branciforte a la Real Academia agradeciendo los sentimientos expresados por su regreso a España y fina memoria de la virreina y de su hija. Marzo 19 de 1797.

974. Renuncia del consiliario de la Real Academia, don José González de Castañeda, por enfermedad. 1797.

975. Oficio de Branciforte a la Real Academia informando que el consiliario don José González de Castañeda solicita le sea admitida su renuncia. Agosto 8 de 1797.

976. Minuta del oficio de la Real Academia al virrey Branciforte dando razones para no admitir la renuncia del consiliario don José González de Castañeda. 1797.

977. Oficio del virrey Branciforte en que expresa su conformidad para que don José González de Castañeda continúe como consiliario de la Real Academia. Septiembre 20 de 1797.

978. Oficio de los señores capitulares, Juan José Gamboa y Joaquín José Ladrón de Guevara, destinados a la colectación de limosnas para la canonización del venerable siervo de Dios fray Felipe de 
Jesús, a fin de que por los individuos de la academia, se den para el efecto aquellas cantidades que juzguen conveniente. Marzo 30 de 1797.

979 a 987 . Documentos sobre el envío de 2 cajones con efectos destinados a la Real Academia. 1797.

988. Acuse de recibo para su envío a España de tres cajoncitos conteniendo 1,300 ejemplares del grabado de la Plaza Mayor con la estatua ecuestre de Carlos IV. Propiedad de Branciforte. Veracruz. Octubre 20 de 1799. José Ignacio de la Torre.

989. Oficio del virrey Branciforte al presidente de la Real Academia trasladándole la comunicación de don Eugenio de Llaguno, de febrero 13 de 1797, en que dice que Francisco Xavier Ramos pintor de cámara de $\mathrm{S}$. M. terminó el cuadro que le encargó la academia, que expresa "la segunda aparición de Jesucristo a los Apóstoles, cuando Santo Tomás salió de su incredulidad tocando con sus dedos la cicatriz del costado". Dimensiones: 10 pies de alto por 7 y medio de ancho. Valor: 15,000 reales de vellón. Julio 31 de 1797.

990. Minuta del oficio al virrey Branciforte acusando recibo del suyo (documento 989) acerca del cuadro pintado por don Francisco Xavier Ramos. Agosto 5 de 1797.

991. Superior orden para que el director de arquitectura pase a reconocer y ejecutar varias obras en el camino de Toluca. Branciforte. Diciembre 28 de 1797.

992. Oficio del director de arquitectura al presidente de la Real Academia adjuntándole la Superior Orden (documentos 991) en que se le comunica que pase a reconocer varias obras en el camino de Toluca. Avisa cuando ha de ir. Enero 9 de 1798. Antonio Velázquez.

993. Oficio del virrey Branciforte al presidente de la Real Academia trasladando otro de don Eugenio de Llaguno, de 20 de agosto de 1798, diciendo que se ha presentado don Gregorio Ferro, director de la Real Academia de San Fernando a decir que en 1792 se encargaron por la Academia de San Carlos varios cuadros a don Francisco Ramos, quien pintó uno, que es apaisado, de seis varas de alto por cuatro de ancho que representa el pasaje de la mujer adúltera, que será una buena lección para los jóvenes que se dedican a las artes y que recomienda se compre, que podrá adquirirse por $\$ 1,000$. Branciforte: que informe el director de pintura. Enero 20 de 1798.

994. Minuta del oficio con el cual se envió al virrey Branciforte, copia certificada del acuerdo de la junta de gobierno de la academia, 
sobre la compra de un cuadro La mujer adúltera, del pintor Francisco Ramos, de la Real Academia de San Fernando. 1798.

995. Instancia del director de arquitectura, don Antonio Velázquez, sobre que se le conceda licencia para pasar a reconocer la obra del Santo Desierto que está a su cargo. Mayo 27 de 1798.

996. Oficio del Real Tribunal de Minería participando hallarse con superior facultad para proponer en terna los sujetos que juzgue más idóncos para la plaza de catedrático en la clase de matemáticas del colegio de la Purísima Concepción de Guanajuato, a fin de que si hubiese algunos discípulos en la academia que quisieren oponerse se les haga saber que lo ejecuten. Julio 28 de 1798.

997. Solicitud del arquitecto don José Gutiérrez para que se le conceda licencia para curarse; acompaña certificado dado por el facultativo don José Carmona. Octubre 2 de 1798.

998. Instancia de don Diego Pérez Valdés sobre que se le dé certificación de haber cursado en la academia y hecho sus progresos en ella, en el ramo de arquitectura. Mayo de 1798.

999. Instancia de don Luis de Tola sobre que por medio de los directores se les den certificados de la aplicación y progresos que ha hecho en las artes. Enero 29 de 1798.

1000. Solicitud del Académico de Mérito, don Luis Martín sobre que se le ponga en la lista de la guía de forasteros. 1798.

1001. Instancia del Académico de Mérito, don José Gutiérrez sobre el asunto de sueldo. Junio 1o. de 1799 (1798?).

1002. Oficio de don Cosme de Acuna participando haberse dignado $\mathrm{S}$. M. nombrar pintor de cámara (para dibujar unas láminas de un libro de equitación). Mayo 25 de 1798.

1003. Minuta del acuerdo de la junta de gobierno, felicitando a don Cosme de Acuña por su nombramiento y que tal mérito constará en las actas. Septiembre 24 de 1798.

1004. Solicitud de Ignacio Reyes y Torres sobre que se le dé certificación de haber asistido a la academia por el espacio de ocho años y sacado varios premios, a fin de poder examinarse en el arte de platería. Se le dio el 24 de octubre de 1798.

1005. Don Cosme de Mier envía expediente para examen de don José María Delgado y Fuentes, para título de agrimensor. Marzo 26 de 1798.

1006. Minuta del oficio dirigido a don Cosme de Mier sobre que tuvo lugar el examen de don José María Delgado y Fuentes para agrimensor y que resultó aprobado. Abril 23 de 1798. 
1007. Certificado del examen para agrimensor de don José María Delgado, en que resultó aprobado. Diego de Guadalajara y Tello. Antonio Velázquez. Abril 17 de 1798.

1008. Oficio con que se adjunta la solicitud de don Norberto Francisco Larrañaga, para examen de agrimensor. Noviembre 17 de 1798. Azanza.

1009. Copia del certificado del examen de don Norberto Francisco Larrañaga, para agrimensor, en que resultó aprobado. Diciembre $1^{\circ}$ de 1798.

1010. Oficio de la Real Academia al virrey Azanza acompañando copia certificada del resultado del examen para agrimensor de don Norberto Francisco Larrañaga.

1011. Certificado del examen (aprobado) de don Norberto Francisco Larrañaga, para agrimensor. Diego de Guadalajara y Tello. Noviembre 29 de 1798.

1012. Oficio del virrey Branciforte para que se proceda al examen para agrimensor, de don Manuel Pérez de Solís. Marzo 15 de 1798.

1013. Certificado del examen para agrimensor de don Manuel Pérez de Solís en que resultó aprobado. Diego de Guadalajara y Tello. Antonio Velázquez. Abril 17 de 1798.

1014. Minuta del oficio al virrey Branciforte acompañando copia certificada del examen de don Manuel Pérez de Solís. Abril 26 de 1798.

1015. Solicitud del Académico Supernumerario, don Francisco Ortiz sobre que se le conceda el grado de Académico de Mérito, asignándosele, por los directores de arquitectura, la obra que haya de ejecutar a este fin. 1798.

1016. Oficio del virrey Branciforte participando anticipadamente su próximo regreso a España. Orizaba, mayo 24 de 1798.

1017. Oficio de la Real Academia al virrey Branciforte, en respuesta del suyo en que participa su próximo regreso a España. Mayo 28 de 1798.

1018. Contestación del virrey don Miguel de Azanza a la carta de felicitación de la Real Academia con motivo de su arribo a este reino. Junio 11 de 1798.

1019. Sobre la construcción de casas en la Plaza de Metepec. Noviembre 11 de 1799. Azanza.

1020. Sobre examen y aprobación de los planos formados para el reedificio del puente de Ixmiquilpan. 1799.

1021. Sobre el examen y calificación del plano formado para la construcción de un puente en el Molino de Río Hondo. 1799. 
1022. Sobre que se proceda al examen de don José Guridi y Alcocer para ejercicio de agrimensor. 1799.

1023. Sobre el examen y aprobación de don Juan Rodríguez de León para ejercicio de agrimensor. 1799.

1024. Sobre el examen y aprobación de don Juan José Romero para el ejercicio de agrimensor. 1799.

1025. Renuncia de don Luis de Tola a la pensión de que gozaba en el ramo de arquitectura. Enero de 1799.

1026. Oficio de don Juan Ignacio Serralde sobre que su compañero don Dionisio López Dena descubrió unas minas de taldre y que envía muestras para su examen. Septiembre 20 de 1799. Certificado al pie de los directores Rafael Ximeno y Planes y Ginés de Andrés y de Aguirre, sobre que el taldre examinado lo hallaron mejor que el de China. Septiembre 23 de 1799.

1027. Instancia del Académico de Mérito, don José Gutiérrez sobre que la junta de policía devuelva su título, detenido por espacio de 14 meses y se abstenga de mandarlo pasar a la junta de gremios. Abril 19 de 1799.

1028. Superior oficio avisando la llegada a Veracruz, en el navío San Ildefonso, de un cajón con un cuadro La segunda aparición de Jesús a los Apóstoles, del pintor Francisco Xavier Ramos. Febrero de 1799.

1029. Oficio de don Cosme de Acuña participando haber sido nombrado por S. M. teniente director de la Real Academia de San Fernando, en el ramo de pintura (por muerte de don Francisco Bayen). Octubre 24 de 1795 (el expediente se encuentra registrado en el año de 1799).

1030. Expediente sobre perjuicios que se siguen al arte de la pintura en tolerancia de los que sin examen ponen obradores. 1799. Memorial de los profesores de la Noble Arte de Pintura. Firmado por: Andrés López, Rafael Gutiérrez, Joaquín Esquivel, Manuel Reyes, Francisco Caplera, José Montero, Juan Nepomuceno Figueroa, José Marcelo Muñoz, José Guerrero, Mariano Guerrero, José de Labastida, Alejandro Garcés, Domingo Mansi, Mariano Morelos, Martín Gaitán, Domingo Ortiz, Manuel de Unzueta, licenciado José Martínez Sanz de Olmedo (interesante copiarlo íntegro).

1031. Informe de los Académicos de Mérito: Rafael Ximeno y Planes, Ginés de Andrés y de Aguirre, Manuel Tolsá y Joaquín Fabregat, sobre la instancia de los profesores de pintura (documento 1030) para que se tomen providencias contra los que sin examen ponen obradores. Dicen "que debe ponerse remedio"; que se examinen y 
que se nombren tasadores de pintura y escultura, conforme a los estatutos. Agosto 3 de 1799.

1032. Oficio del presidente de la Real Academia, marqués de San Román, al virrey don Miguel José de Azanza, trasladando el acuerdo de la junta sobre que ponen en sus manos el asunto promovido por los profesores de pintura, para que cese la tolerancia de los que sin examen tienen obradores (según el término vulgar equivalente a "estudio"). Noviembre 8 de 1799.

1033. Oficio (firmado-Borbon), diciendo que en el ocurso que han promovido los profesores de pintura se versa también el interés o daño de los indios "a quien se supone que no menos que los españoles y mulatos, contribuyen a los desórdenes y abusos..."; que se pase el expediente al fiscal protector de indios. Noviembre 29 de 1799.

1034. Oficio del fiscal protector de los indios (Saparsurieta), diciendo: que en el adoptar una providencia general sobre los pintores no examinados, "se pulsan graves dificultades en la práctica, siendo muy duro que a tantos infelices como hay, principalmente indios sin contar con otra cosa para su subsistencia que lo poco que ganan en hacer estas o las otras pinturas ligeras y de poca dificultad, se les prive de algún destino..."; "que lo más que podría hacerse en el caso es que se pusiese algún distintivo en las casas u obradores de los pintorcs aprobados y así el público no se engañaría..."; que se forme una lista de todos los pintores aprobados que hay en el Reino. . . etcétera. Diciembre 31 de 1799.

Acuerdo del virrey Azanza: como pide el señor fiscal prołector... Enero 3 de 1800.

1035. Memorial del pensionado don José María Vázquez, quien solicita la plaza vacante de director de pintura... "acogido de la mente de $\mathbf{S} . \mathbf{M}$. que es patrocinar a los americanos jóvenes y aplicados..." (relata sus méritos) (interesante. Oleógrafo). Agosto 7 de 1800. 
DOI: http://dx.doi.org/10.22201/iie.18703062e.1968.sup3

En la Imprenta Universitaria, bajo la dirección de Rafael Moreno, se terminó la impresión de: Guía del archivo de la Antigua Academia de San Carlos 17811800 , el día 12 de marzo de 1969 . La composición se paró en tipos Electra 10:11 8:9. Se tiraron 1500 ejemplares. 
DOI: http://dx.doi.org/10.22201/iie.18703062e.1968.sup3 
DOI: http://dx.doi.org/10.22201/iie.18703062e.1968.sup3 
DOI: http://dx.doi.org/10.22201/iie.18703062e.1968.sup3 